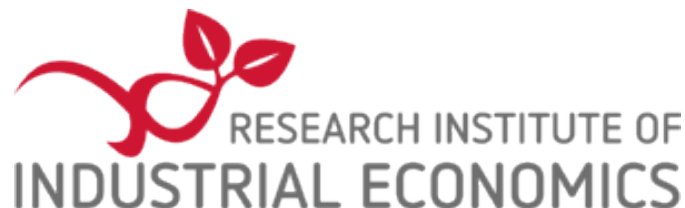

INDUSTRIAL ECONOMICS

IFN Working Paper No. 1161, 2017

\title{
Tax Progressivity and Top Incomes: Evidence from Tax Reforms?
}

Enrico Rubolino and Daniel Waldenström 


\title{
Tax progressivity and top incomes: Evidence from tax reforms*
}

\author{
Enrico Rubolino ${ }^{\dagger}$ and Daniel Waldenström ${ }^{\ddagger}$
}

February 20, 2017

\begin{abstract}
We study the link between tax progressivity and top income shares. Using variation from large-scale Western tax reforms in the 1980s and 1990s and the novel synthetic control method, we find large and lasting boosting impacts on top income shares from the progressivity reductions. Effects are largest in the very top groups while earners in the bottom half of the top decile were almost unaffected by the reforms. Cuts in top marginal tax rates account for most of this outcome whereas reduced overall progressivity contributed less. Searching for mechanisms, real income responses as measured by growth in aggregate GDP per capita, registered patents and tax revenues were unaffected by the reforms. By contrast, tax avoidance behavior related to the management of capital incomes in the very income top appears to lie behind the observed effects.
\end{abstract}

*We thank Spencer Bastani and Håkan Selin for comments and the Swedish Research Council for financial support.

†Uppsala University.

\# Research Institute of Industrial Economics and Paris School of Economics, CEPR and IZA. Email: daniel.waldenstrom@psemail.eu. 


\section{Introduction}

How does changing tax progressivity affect the distribution of pre-tax income? This question has interested researchers and policymakers alike in the wake of a decline over several decades in income tax progressivity around the Western world. Several studies have examined the issue, looking at either cross-country evidence or within-country variation over the income distribution (see, e.g., Feenberg and Poterba, 1993; Slemrod, 1996; Slemrod and Bakija, 2000; Brewer, Saez and Shephard, 2010; Bach, Corneo and Steiner, 2013; Förster, Llena-Nozal and Nafilyan, 2014; Piketty, Saez and Stantcheva, 2014; Duncan and Sabirianova Peter, 2016; Frey and Schaltegger, 2016 and Saez, 2017), but the complex interdependence between income taxation and income inequality poses powerful hurdles to identify this relationship and it is fair to say that consensus has not been reach over how it looks.

In this paper, we approach the question of how tax progressivity affects income inequality from a new angle: studying the effect of tax reforms on the income shares earned by the top of the income distribution. Tax reforms are particularly tractable study objects for our purposes. First, they offer a distinct and usually large-scale source of variation. Second, they account for much of the recorded decline in Western tax progressivity over recent decades. Third, tax reforms have not been studied extensively before in the context of explaining income inequality change.

Our analysis covers all personal income tax reforms carried out in Western countries since the 1970s, but for identification purposes we focus on three cases where progressivity decreased extraordinarily much: Australia in 1987, New Zealand in 1989 and Norway in 1992. Analyzing single events puts specific requirements on the statistical methods used, and in our baseline analysis the identification strategy relies on the newly created synthetic control method (SCM) of Abadie, Diamond and Heinmueller (2010). The idea behind the SCM is to construct a control group that captures what would have happened in the absence of treatment. Rather than choosing one or more countries to use as a comparison group (as in difference-in-difference estimation), we create a synthetic control country in the form of a weighted average of nontreated countries selected based on how similar they are to the treated country in terms of levels and trends in top income shares, structure of the tax system and other relevant background characteristics. Several robustness tests are made to examine the validity and sensitivity of the assumptions underlying the SCM.

In addition to the SCM-analysis we run standard panel regressions. While these partly serve to complement the main SCM analysis, they also allow us to examine mechanisms in the progressivity effects such as the relative role of reduced tax rate progression over the distribution versus cuts in top marginal tax rates. In addition, they allow us to investigate more subtle dimensions of tax reforms, such as how changes in the number of tax brackets or broadening of the tax base (Kopczuk, 2005) affect the income distribution.

In a final analysis, we study the impact of tax reforms on economic efficiency. As Saez 
(2004) noted, the intellectual weight behind many of the dramatic cuts in top tax rates during the 1980s adhered to supply-side economics and a broad notion that lower tax rates fuel economic activity. We evaluate this hypothesis by running SCM estimations replacing top income shares by three indicators of real activity: GDP per capita, number of registered patents per capita, and total tax revenues over GDP. While these are admittedly coarse indicators of efficiency, they capture policy-relevant dimensions of real economic activity and are therefore interesting to study in contrast to inequality outcomes.

Our findings show that the reductions in tax progressivity coming with the studied tax reforms had a strong boosting impact on top income shares. The income share of the top percentile increased by between 20 and 50 percent in the reformed countries relative to their synthetic controls. The size of this impact was highest in the very top: income shares of the top 0.1 percentile rose by between 50 and 100 percent whereas they hardly changed at all for the lower half of the top decile. We cannot find any significant impact by tax reforms on economic output or other efficiency indicators, suggesting that the effect on top income shares was rather due to a redistribution of exisiting resources than to new resources being generated by the income elite. Instead, the patterns are in line with tax planning and increased capital incomes among top income earners.

The paper contributes to two literatures. First, most relevantly to the above-cited tax policy studies, particularly those dealing with tax progressivity effects on income distribution. Furthermore, we add to the broader top incomes literature where there are still few studies that have established the determinants of the trends in top income shares. While some attempts are made to study the association between top income taxation and top income shares (e.g., Roine, Vlachos and Waldenström, 2009; Atkinson and Leigh, 2013; Piketty et al., 2014) they primarily offer correlational evidence and do not make attempts to clarify causal mechanisms.

\section{Analytical framework}

Our purpose is to estimate the effect of tax progressivity on top incomes, and to do this we need to account for all the effects that a tax reform may induce to reported income. The starting point is the optimal income taxation framework described in, e.g., Feldstein (1995, 1999), Slemrod and Bakija (2000), Gruber and Saez (2002), Saez (2004), Saez, Slemrod and Giertz (2012), Piketty et al. (2014) and Saez (2017). This uses an extension of the static labor supply model where individuals maximize their utility that depends positively on disposable income, which they can consume, and negatively on reported income, on which they have to pay taxes. The elasticity of reported income with respect to the net-of-tax rate is defined as:

$$
\epsilon=\frac{1-\tau}{z} \frac{\partial z}{\partial(1-\tau)}
$$

where $z$ denotes reported income and $1-\tau$ the net-of-tax rate. This equation captures all the behavioral responses to a change in marginal tax rate. These may depend on the specific charac- 
teristic of the tax system, such as the availability of deductions or tax avoidance opportunities, and on other things such as how broadly defined the tax base is.

It is well-known that top incomes may respond differently to income taxation than the rest of the taxpaying population. In a recent paper, Piketty et al. (2014) propose an extended variant of the optimal taxation model of top incomes in which top incomes respond to marginal tax rates through three main channels: standard labor supply, tax avoidance, and compensation bargaining, all summing to $\epsilon$ in equation (1). The first top income elasticity is the standard labor supply elasticity, reflecting real economic responses to the net-of-tax rate (more hours of work, more intense effect per hour worked, occupational choice etc.). The second elasticity reflects tax planning and tax avoidance behavior of top-income minimizing their taxes paid. Several studies have provide compelling evidence that top incomes may respond to tax changes through tax avoidance and income sheltering (e.g., Slemrod, 1996; Auerbach, 1988; Saez, 2017). The third top income elasticity captures the incentive to bargain more aggressively for pay increases in response to lower marginal tax rates since that gives the top earners a larger fraction of the remuneration.

We use these models of top income taxation as basis for identifying the effect of tax progressivity on top income shares. The baseline estimation will be close in spirit to the empirical panel regression model specified in in Piketty et al. (2014): $y_{i t}=\epsilon \times \log (1-M T R)_{i t}+\beta X_{i t}+u_{i t}$, where $y_{i t}$ denotes a top income share in country $i$ and time $t, M T R$ is the marginal tax rate and $X_{i t}$ are control variables such as time trend or country fixed effects. This regression gives the average expected link between the net-of-tax rate and the top reported income share. A related estimation approach is that of Saez (2017) where medium-term tax-reform responses of top incomes are computed by subtracting a counterfactual top-share change from the observed top-share change. While rudimentary, this medium-term response is actually close in spirit to the causal estimation of top marginal tax rates that we attempt to do using a different, and more comprehensive, identification strategy.

\section{Tax reforms of the 1980s}

The evolution of Western personal income taxation since the 1970s exemplifies how tax reforms are important drivers of tax progressivity change. In particular, the 1980s was an era when several countries restructured their income tax systems. According to a survey by Brys et al. (2011), these reforms may have differed in scale and scope but they shared an overall ambition to reduce top marginal tax rates, broaden tax bases and reduce the number of income tax brackets.

We wish to study tax reforms that significantly diminished the progressivity of personal income taxation since this facilitates identifying any effects on the income distribution. As a consequence, we will disregard all the minor and more gradual reforms that took place during our studied period. 


\subsection{Identifying significant tax reforms}

There are several ways to define and measure tax progressivity. We follow Musgrave and Thin (1948) and choose the commonly used progressivity measure average rate progression (ARP). Denote $Y_{0}$ and $Y_{1}$ two income levels in the income distribution, with $Y_{0}<Y_{1}$, and $T_{0}$ and $T_{1}$ their respective tax liabilities. The average tax rate, ATR, is thus $A T R=T / Y$ and this allows us to write the ARP as follows:

$$
A R P=\frac{A T R_{1}-A T R_{0}}{\left(Y_{1} / Y_{0}\right)-1}
$$

Empirically, we compute the ARP using data on top incomes and average incomes in different countries over time (see further below in the data section). For country $i$ at time $t$, we assign to the income levels an ATR of a top-income taxpayer, $A T R_{i, t}^{\text {top }}$, and an ATR to an averageincome taxpayer, $A T R_{i, t}^{a v g}$. Our country-year measure of tax progressivity then becomes

$$
A R P_{i, t}=\frac{A T R_{i, t}^{t o p}-A T R_{i, t}^{a v g}}{\left(Y_{i, t}^{t o p} / Y_{i, t}^{a v g}\right)-1} .
$$

Finally, our key statistic for evaluating and classifying changes in tax progressivity in countries at different points in time by defining the change in this empirical ARP as

$$
\Omega_{i, t}=A R P_{i, t}-A R P_{i, t-1}
$$

Negative values of $\Omega_{i, t}$ reflect progressivity-reducing reforms and the larger the $\Omega_{i, t}$ the larger the progressivity change. We compute $\Omega_{i, t}$ since 1981 (the earliest year for which we have detailed fractile-specific tax data, see data section below) for 18 OECD countries and can thereby observe which tax reforms that led to the largest negative change in structural progressivity. ${ }^{1}$

Figure 1 plots tax reforms according to their impact on progressivity. Most of them lowered progressivity, but the of the reforms stand out: New Zealand in $1989(\Omega=-0.047)$, Norway in $1992(\Omega=-0.030)$ and Australia in $1987(\Omega=-0.026)$. The reforms in the US and the UK during the 1980s were also lowered progressivity, but not as significantly and not as distinctly as in the other three countries. Furthermore, the UK and US reforms occurred in several steps over a sequence of years (see Piketty and Saez, 2007; Adam et al., 2010; Brewer et al., 2010). For this reason, we will in the subsequent analysis only consider the tax reforms in Australia, New Zealand, and Norway.

[Figure 1 about here]

\footnotetext{
${ }^{1}$ In Appendix A4 is provided a brief description of the tax reforms for which $\Omega_{i, t}$ has been computed, and the corresponding numerical value. Note that $\Omega_{i, t}$ relies on the computation of the ATRs. Data limitations (see further in the data section below) imply that our empirical ATR could differ from the effective tax rate since some tax components are not available. It follows that if additional components of overall taxation are considered, it could be the case that other reforms have produced a larger erosion in structural progressivity. We also compute the marginal rate progression in an equivalent way, using marginal tax rates instead of ATRs. Results are essentially the same.
} 


\subsection{The Australian Tax Reform}

The Australian tax reform was announced on September 19, 1985 (Keating, 1985), but it received the royal assent only in June 1987. ${ }^{2}$ The highest marginal income tax rate was reduced from 60 percent to 49 percent and the tax base was broadened. Taxation of realized capital gains and fringe benefits were also changed, and full dividend imputation was introduced. Burkhauser et al. (2015) note that "under the new 100 percent imputation tax system in the reform legislation, these company taxes effectively became withholding taxes since their payment could be used to offset personal income tax on dividends or any other taxes.". Hence, this was a major reduction in the effective tax rate on dividends, with the greatest reduction in tax rates going to those with the lowest marginal income tax rate. ${ }^{3}$ The company tax rate was aligned to the top personal tax rate (at 49 percent). However, this alignment lasted only two years. Such a high company tax rate proved unsustainable, and the rate was reduced to 39 percent in the 1988 business tax reform, without a same change in the income tax rate. All those changes have deeply transformed the Australian tax system providing a well-defined swing in the fiscal institutional, where the starting point can be identified by the change in the treatment of capital gains implemented in June 1986, i.e., the 1985-1986 fiscal year. ${ }^{4}$ Therefore, effects on top incomes are likely to begin before 1987, the year we use to refer to the reform.

Figure 2 displays the historical evolution of the top percentile income share, the statutory top marginal tax rate, and the average rate progression. Atkinson and Leigh (2007) and Burkhauser et al. (2015) discuss the long-term trends and their potential driving forces. As for the upturn since the 1980s, they emphasize the role of tax changes. For example, the 1988 spike reflected a combination of the top tax cut, a housing price boom and reduced top effective marginal tax rate on dividends. Burkhauser et al. (2015) show that the size of the spike is substantially reduced when excluding dividend income (See appendix Figure C5 for a comparison between the two variants of top percentile income share). The importance of realized capital gains and their taxation for top income series is also emphasized by Burkhauser et al. (2015). Even though they were taxed since 1972, only a small share of them was part of the tax base until the reform in 1987 when they were fully taxable (though at a lower rate).

\footnotetext{
${ }^{2}$ Labor M.P. and Government Treasurer Paul Keating introduced a program for fundamental tax reform announcing, in his opening statement: "Today we are addressing a crisis in our national taxation system that has been left by a succession of Governments to compound year upon year. There was a time when Australia had a reasonably sane and credible taxation system. But that time is long gone. The system has been broken and beaten by an avalanche of avoidance, evasion, and minimization. It is the deterioration and decay that occurred in the late 1970s and early 1980s that has now made substantial reform so essential.'(Keating, 1985, p.2).

${ }^{3}$ One reason for the passage of this legislation was to treat company profits in the same way of how profits by trusts were treated (Burkhauser et al., 2015). The Australian government (Australian Government, 1985) identified the shifting from companies and partnership to public and private trusts as one of the major threat to the tax system since it was steadily becoming a relatively low cost legal vehicle for doing business in the 1970s and 1980s that successfully circumvent the classical taxation system. According to tax record data, trusts grew from 117,616 (aggregate net income of 0.3 billion dollars) in 1972 to 258,846 (aggregate net income of 2.7 billion dollars) in 1982. The government declared that "the phenomenal growth in recent years in private business and trading trusts has reflected a desire to avoid the two-tier taxation of company income which can feature under the private company structure.” (p.55).

${ }^{4}$ Note that Australia and New Zealand have fiscal year starting on 1 July and ending on 30 June.
} 


\subsection{The New Zealand Tax Reform}

The tax reform in New Zealand in 1989 gave rise to the largest measured progressivity reduction of all the reforms we study. The reform took place during an era of profound economic change, when many economic institutions were liberalized and deregulated (Evans et al., 1996; Atkinson and Leigh, 2008). The tax reform broadened the tax bases, sharply reduced the highest marginal tax rates (the top rate decreased from 66 to 33 percent) and reduced the number of tax brackets to two. Other important changes were a restructuring of the sales and other indirect taxes and a change in corporate taxation, among other things making dividend payments more attractive. The effect of this switch in 1989 is clearly shown in Figure $2^{5}$, as well as the upturn of the top percentile since the mid-1980s. A fringe benefit tax was also put in place in 1985 at an initial rate of 45 percent.

Atkinson and Leigh (2008) identify some potential factors driving the surge in top incomes during this period. They state that "progressive taxation may have contributed to the fall in top income share over the 1930s and 1940s, with the top marginal tax rate rising from 25 percent in 1930 to 65 percent in 1940, peaking at 77 percent from 1942 to 1945. Likewise, top tax rates may have been a factor in the growth in top income shares during the late 1980s." (p.162). In addition, they provide evidence supporting the hypothesis that lower marginal tax rate had a positive effect on the top income percentile, estimating a time series regression showing that a 10-percentage point marginal tax rate cut increased the top share owned 0.6 points (Table 2, panel b, column 5).

\subsection{The Norwegian Tax Reform}

The Norwegian tax reform in 1992 was mainly inspired by the US tax reform of 1986 and its ambitions to reduce tax-induced distortions by lowering statutory tax rates and broadening tax bases (Aarbu and Thoresen, 1997). Similar to the Australian and New Zealand reforms, the reform in Norway substantially lowered the top marginal tax rates but only made small reductions of taxes on lower incomes. Before 1992, the tax system has been more or less unchanged. Both the pre- and the post-reform income tax system consist of two tax bases: net and gross income. The reform affected taxation of wage earners, self-employed and corporations. Aarbu and Thoresen $(1997$; 2001) describe the main changes in the personal tax structure. The most important change was that the progressive national tax was removed. The tax rate on net income was reduced from a maximum of 40.5 percent to a flat rate at 28 percent. The marginal tax rate on capital income was reduced likewise. Dividends have become increasingly more important as a source of income (Aarbu, Thoresen, 1997), stimulated by the reduction in the corporation tax.

\footnotetext{
${ }^{5}$ Similarly is the case of 1999 spike. Since the opposition Labour Party announced in 1998 that, if elected, would have raised top tax rate from 33 to 39 percent in the 2000 tax year (Atkinson and Leigh, 2008), many taxpayers decided to realize business earnings in the 1999 tax years, boosting up the top income shares in that specific year.
} 
Figure 2 shows the evolution of the top percentile's income share. ${ }^{6}$ The most striking feature is clearly the turning point in 1992, the year of the tax reform. While the early part of the postwar period was characterized by a highly progressive income tax schedule, the 1992 tax reform clearly represents a structural break.

[Figure 2 about here]

\section{Estimation method and data}

Estimating the causal impact of tax progressivity change on top income shares is associated with several difficulties. The key challenge is that both outcomes are simultaneously determined, depending on each other as well as a number of other factors. Previous studies have used different methodologies to estimate the progressivity-inequality link, most of them being limited in their ability to distinguish between correlation and causation. Our estimation approach is close in spirit to the empirical panel regression model of Piketty et al. (2014) and the differencein-difference estimation of medium-term tax-reform effects by Saez (2017).

We use the novel synthetic control method (SCM) which was developed in the seminal paper of Abadie et al. (2010). This approach, described in detail below, estimates counterfactual outcomes by combining information from many control variables and potential control units, and it is particularly useful when studying rare outcomes in single countries, such as tax reforms.

As complement to the SCM, we also present cross-country panel regressions where we estimate the relationship using standard difference-in-difference methods with controls for time trends and country fixed effects. Although the OLS approach is less suitable for analyzing the causal impact of reforms, it gives a broad robustness check and also allows us to examine the role of certain mechanisms. Reassuringly, the SCM and the difference-in-difference generate similar results in both sign and magnitude.

\subsection{Synthetic Control Method}

The SCM compares a certain outcome in a single treated country with the same outcome in a constructed counterfactual country - a synthetic control - consisting of a weighted combination of those non-treated countries that are the most similar to the treated country in terms of levels and trends of both the outcome variable in question and various relevant background characteristics.

Consider a total of $J$ countries, indexed by $j$, where the first country $(j=1)$ is the treated country and countries 2 to $J(j=2, \ldots, J)$ compose the donor pool from which the synthetic control group will be generated. The pre-treatment period $T_{0}$ and post-treatment period $T_{1}$ sum

\footnotetext{
${ }^{6}$ We use the series from the WID, showing reported taxable incomes. As Alstadsaeter, Jacob, Kopczuk and Telle (2016) recently showed, these shares are much below the actual top income shares after a dividend-tax reform in 2005 when the reporting of retained earnings was changed. Fortunately, because this reform comes after our estimation window its impact on top income data does not influence our results.
} 
up to the full sample length. The aim of the analysis is to measure the effect of the tax reform on top income shares throughout $T_{1}$, selecting a synthetic control group that best resemble the preintervention characteristics of the treated country. The synthetic control is defined as a weighted average of the countries in the donor pool. That is, a synthetic control can be represented as a $(J-1) \times 1$ vector of weights $W=\left(w_{2}, \ldots, w_{J}\right)^{\prime}$, with $0 \leq w_{j} \leq 1$ for $j=2, \ldots, J$ and $w_{2}+\ldots+w_{J}=1$. The vector $W$ is chosen such that the characteristics of the treated country during $T_{0}$ are best approximated by the characteristics of the synthetic control. Let $Y_{j, t}$ be the top income shares of unit $j$ at time $t$. Moreover, let $Y_{1}$ and $Y_{0}$ be a $T_{1} \times 1$ vector and a $T_{1} \times(J-1)$ matrix collecting the post-treatment values of top income shares in the treated country and in the synthetic control respectively. For a post-treatment period $t$, the difference in top income shares between the treated country and the synthetic control can be defined as:

$$
\alpha_{1, t}=Y_{1, t}-\sum_{j=2}^{J} w^{*} Y_{j, t}
$$

The synthetic control, $W^{*}$, is chosen so that the size of the differences is minimized. The counterfactual outcome can be modeled as:

$$
Y_{j, t}=\gamma_{t}+\theta_{t} Z_{j}+\lambda_{t} \mu_{j}+u_{j, t}
$$

where $\gamma_{t}$ is a time fixed effect, $Z_{j}$ is a vector of control variables that are important for the evolution of top income shares, $\mu_{j}$ is a vector of unobserved factors affecting the top income shares (but that does not cause the tax reform analyzed), and $u_{j, t}$ is an idiosyncratic shock. Selecting a weighted average of the untreated countries, the model in (6) becomes:

$$
\sum_{j=2}^{J} w_{j} Y_{j, t}=\gamma_{t}+\theta_{t} \sum_{j=2}^{J} w_{j} Z_{j}+\lambda_{t} \sum_{j=2}^{J} w_{j} \mu_{j}+\sum_{j=2}^{J} w_{j} u_{j, t}
$$

It means that if the model in (7) holds, top income shares are affected by some variables, both observed and unobserved. By constructing (7), it is artificially created a counterfactual which is affected by the same variables (both known and unknown) that have effect on the treated country. Abadie et al. (2010) prove that choosing the vector $W^{*}$ so that both all weighted sums of control variables

$$
\sum_{j=2}^{J} w_{j}^{*} Z_{j}=Z_{1}
$$

and the pre-treatment outcomes match the treated country

$$
\sum_{j=2}^{J} w_{j}^{*} Y_{j, 1}=Y_{1,1} ; \sum_{j=2}^{J} w_{j}^{*} Y_{j, 2}=Y_{1,2} ; \quad \ldots \quad ; \sum_{j=2}^{J} w_{j}^{*} Y_{j, T_{O}}=Y_{1, T_{O}}
$$

then, even when $\mu_{j}$ is unobserved, the weighted average of the donor pool is an unbiased 
estimator of the potential outcome, and $\hat{\alpha_{1, t}}=Y_{1, t}-\sum_{j=2}^{J} w^{*} Y_{j, t}$ represents an estimator of the true treatment effect.

Compared to regression-based methodologies, the SCM offers significant advantages over the standard difference-in-difference method when it comes to estimate effects of treatments in single countries. However, the SCM relies on some assumptions that need to be scrutinized critically and we do this in a series of sensitivity checks reported below. Specifically, we run "in-time" and "in-space" placebo tests, vary the control variables used to construct synthetic control groups and examine post-treatment trends of control variables in treated and synthetic controls.

\subsection{Data}

Our dataset contains annual observations of income, tax and control variables collected for 18 countries over the period 1960-2010. Details about these series are provided in Appendix A, including information about sources and discussions about where and when ambiguities are found in the data and how they are accounted for.

Income data: Top income shares and average incomes for different top income fractiles come from the World Wealth and Income Database (WID). As extensively discussed by Leigh (2009), Atkinson, Piketty and Saez (2011), and Roine and Waldenström (2015), these series stem from administrative tax sources and have been compiled using a common methodology for all countries, offering a high degree of comparability over time and space. Among the problems with these tax data is that they do not allow for a complete separation of income sources (earnings, capital income) to scrutinize income-shifting and other avoidance behaviors among top earners.

Tax data: We have data on marginal tax rates and average tax rates. Two different kinds of marginal tax rates are used. $M T R^{t o p}$ denotes the statutory top marginal income tax rate in the tax schedule, retrieved from Piketty et al. (2014) for 18 countries over the period 1960-2010. While this has been one of the most commonly used measures in the previous literature, it is quite problematic since its coverage of how many that actually pays it varies greatly over time and space (between virtually nobody and over one third of the population pays it in our country sample). Therefore we also use a more accurate measure, $M T R^{s}$, which shows the marginal tax rate calculated to match the income level of each top-income fractile $s$ in each country and year. We are able to calculate this tax rate annually for 15 countries since 1981 based on tax schedules in the OECD Tax Database (Tables I.1 to I.3) and average top fractile incomes in the WID. An average tax rate, $A T R^{s}$, also specific for each fractile is calculated in a similar manner since 1981.

The tax information in the OECD dataset shows both central and sub-central government personal income taxes schedules for wage income, plus the taxable income thresholds at which these statutory rates apply. ${ }^{7}$ We account for standard deductions, tax credits, basic personal

\footnotetext{
${ }^{7}$ The Database also provides standard tax allowances, tax credits, and surtax rates. The information is appli-
} 
allowances, major national surtaxes, and other provisions in addition to statutory rates and thresholds at both central and sub-central government levels. However, even though we deem our calculations to be improvements, they are not perfect. We are unable to use income sourcespecific effective tax rates, which could differ for some countries and some periods, because that information is not available for most countries in the WID. Furthermore, there are smaller taxes and contributions for specific countries and time periods that could not be included in the general formula for reasons of comparability, but we deem that they are so few and small enough not to have any bearing on the main analysis. ${ }^{8}$

Control variables: Some control variables come from the literature on the determinants of inequality (Atkinson and Piketty, 2007; Roine, Vlachos and Waldenström, 2009; Doerrenberg and Peichl, 2014): GDP per capita, financial development (sum of bank deposits and stock market capitalization as share of GDP), trade openness (trade share in GDP), trade union density as a percent of employees, the share of working age population and technological progress (growth rate of the number of patents) ${ }^{9}$.

Another, particularly important group of control variables, are those that address the endogeneity of tax reforms. The eventuality that a tax reform is caused by variables driving inequality change (or even by the inequality change itself) is to some extent handled by the synthetic control methodology as the counterfactual should possess the same probability of an unexpected increase in the top income shares as well as causing a tax reform. However, we also include additional variables that could be drivers of a tax reform (see Brys et al., 2011 for a detailed discussion). In particular, fiscal imbalances could be key and we therefore include three related variables: gross central government debt as a share of GDP (from Reinhart and Rogoff, 2011), total tax revenues as a share of GDP (OECD, 2016b) and and central government spending as a share of GDP (Roine et al., 2009).

\section{Main results}

We now present the main results of the SCM-analysis. The effect of progressivity-reducing tax reforms on top income shares is measured as the difference between post-reform top income share trends in the treated country and its synthetic control.

\footnotetext{
cable to a single person without dependents. The threshold, tax allowance and tax credits amount are expressed in national currencies. Further explanatory notes may be found in the OECD Explanatory Annex: http://www.oecd.org/ctp/tax-policy/Personal-Income-Tax-rates-Explanatory-Annex-May-2016.pdf.

${ }^{8}$ First, data limitation on both the tax and income sides does not allow to include social security contributions in the ATRs computations. Second, any income tax that might be due on non-wage income is not taken into account. Despite income from interests, dividends and rents represents a minority of total personal income, capital income is, however, significant, particularly in the top of the income distribution. Third, deductions, allowances, and credits that vary by individuals characteristics are not included in the calculations. Fourth, the focus is on annual incomes, which are not a perfect measure of income over the course of a lifetime (Piketty and Saez, 2007). Recent studies (for example, Bengtsson, Holmlund and Waldenström, 2016) have shown that individual income taxes seem to be less progressive from a lifetime perspective than from an annual perspective, because of year-to-year transitory fluctuations in income.

${ }^{9}$ See Table A4 for a full description of all the control variables.
} 
Synthetic control groups are specific for each country and top income fractile, and the following control variables are used in the baseline estimation: GDP per-capita, globalization, annual hours worked, human capital, financial development, trade union density, $M T R^{\text {top }}$, ARP, and debt growth rate. ${ }^{10}$ To limit the number of tables and figures presented below, we refer to Appendix B for outputs concerning weights assigned to each country in the donor pools and all pre-treatment trends.

\subsection{Australia}

Figure 3 reports income shares in Australia (solid lines) and its synthetic control groups (dashed lines) before and after the tax reform was announced. The test results suggest that top income shares increased substantially relative to the synthetic control group as a consequence of the tax reform. Immediately after the reform implementation, income shares increased drastically: a spike in the top percentile group's income share of 1987 implies an increase by 60 percent relative the synthetic control. ${ }^{11}$ Over the first five years, however, the estimated effect of the progressivity reduction on the top percentile group was a 20-25 percent increase in its income share relative to the level of the synthetic control.

Looking at different groups within the top income decile, as shown in the intermediate top shares in the figure's panel b, there are stark differences in responses. The absolute top responded strongest: the 1987 spike in the top 0.1 percentile share represents a 140 percent increase, and in the first five post-reform years the effect is about a 60 percent raise of the group's income share. However, lower down the top decile the treatment effects are much smaller. The income share of the top 5-1 percent group is only marginally (about between zero and ten percent) above the control group.

How should we think about the longevity of the treatment effect in the very top? As the figure shows, the increase in income shares of the very top groups did not die out, and more than twenty years later, in 2010, it was still around one quarter higher than the synthetic counterfactual. However, as the years go by there are many other things influencing the income distribution that eventually implies that the basic assumptions of the SCM become violated. We investigate this issue in one of our robustness checks (reported in appendix C3, figure C3), where post-treatment trends of the control variables used to construct synthetic controls in both treated and synthetic controls are compared. This examination gives no indications of confounding post-treatment effects that would violate the SCM structure, which thus suggests that the lasting differentials in figure 3 do in fact reflect long-lasting treatments effects.

[Figure 3 about here]

\footnotetext{
${ }^{10}$ The choice is made so that several potential determinants of top income shares are considered in the pre-treatment period. The last three variables are selected for capturing the potential endogeneity of the tax reform.

${ }^{11}$ We allocate the treatment (represented by the dashed vertical line) to the 31 December of the year before the comprehensive reform legislation began. That is 1985 for Australia, as discussed above (see section 2.2). Likewise, we impose the treatment on 1988 for New Zealand and 1991 for Norway.
} 
Accounting for the larger reform effects in the highest income groups, one possible candidate explanation is the relative importance of capital income in total incomes. Capital income offers more leeway to manage income streams over time in order to minimize taxes. Realized capital gains is perhaps the most obvious example of such an income, but dividend incomes may also be smoothed or held back for tax purposes. The previous top income literature offers ample evidence that in most Western economies, capital income is indeed much more important for the highest top incomes than for lower top incomes. We use the WID to decompose Australian top incomes across wage and non-wage components and find a consistent increase in the capital income share along the distribution. Looking at the average capital income share during the entire 1980s and 1990s, it was around 25 percentiles in the bottom half of the top decile but around 70 percent in the top 0.1 percentile. If anything, this does not reject the hypothesis of income-shifting behaviors accounting for most of the top share changes caused by the tax reform.

\subsection{New Zealand}

Figure 4 displays the results of the 1989 tax reform effects on top income shares in New Zealand. The results indicate fairly large short-term increases in top income shares, varying from 17 percent (top 10 percent) to 50 percent (top 0.5 percent), though not as large in Australia. The intermediate shares in panel $b$ show that practically all of this increase happened in the upper half of the top decile, where the income share increased approximately 15 percent in the top 1-0.5 percentile group and between five and ten percent in the top 5-1 percentile group. By contrast, in the bottom half of the top decile there was absolute no effect on income shares at all.

When looking at how long the effects lasted over time, we see that they were not as longlived as in Australia. Even in the very top groups, there is no difference between New Zealand and the synthetic controls ten years after the reform.

[Figure 4 about here]

When looking at potential drivers for the results, we must again consider the role of the differential impacts within the top decile. Unfortunately, we cannot study the role of income composition in detail because of a lack of such compositional data across top income groups in New Zealand. We know, however, that the tax changes created strong incentives to boost capital income after the reform of the 1980s and before the reform of 2000. For example, the introduction of an imputation system made it more attractive to pay dividends, and Atkinson and Leigh (2008) argue that this is clearly reflected in the higher 1989 income shares. The raised top marginal tax rate from 33 to 39 percent that was announced in late 1998 and implemented in 2000 encouraged top earners to realize capital gains. In other words, similar to the Australian case there seems as if capital incomes played a role also in the tax-driven rise of top income shares in New Zealand. 


\subsection{Norway}

The SCM-estimated impact of progressivity reductions on Norwegian top income shares during the tax reform in 1992 is presented in Figure 5. The results display similar patterns as in Australia and New Zealand, with top income shares increasing as a consequence of the reform, but from a lower initial level. The top percentile share increased from six to seven-eight percent, which is by roughly one fifth, whereas the top 0.1 percentile increased from around two to around three percent, i.e., by roughly half. The persistence of this effect was around 15 years, similar to what was found for New Zealand but shorter than in Australia.

Lower down in the Norwegian top income decile, we are not able to find any significant reform effects at all. In fact, post-treatment trends in income shares are higher in the synthetic control than in the lower half of the top decile. However, even pre-treatment trends differ markedly and suggest a relatively bad goodness-of-fit for estimated synthetic control group.

\section{[Figure 5 about here]}

When accounting for the differential results within the Norwegian top income decile, we focus as in the other countries on the importance of income composition. Capital incomes seem to have been important also in driving the incomes of the very top Norwegian incomes after the reform. Aaberge and Atkinson (2010) examine several potential drivers of the top income share change in the 1990s, pointing at sharp increases in dividend income and in realized capital gains among high-earning households. Fjærli and Aaberge (2000) point out that the surge is partly explained by income shifting, evidencing as dividend receipts and capital gains received by top decile had increased just after the reform. The panel data analysis made by Aarbu and Thoresen (1997) also highlights that post-reform "winners" are characterized by large increases in capital income.

\subsection{Statistical significance of the results}

The most common way to check the statistical validity of SCM estimations are by way of "inspace" placebo tests. These tests simulate the treatment to members of the donor pool and if results indicate similar, or even larger, effects when the treatment is artificially assigned to countries not directly exposed to the intervention this is evidence against the baseline results being true. Abadie et al. (2015) propose that, as in traditional statistical inference, a quantitative comparison between the distribution of placebo effects and the synthetic control estimate can be performed through the use of pseudo p-values. In this context, a p-value can be constructed by simulating the treatment for each unit in the sample and then calculating the fraction of such effects greater than or equal to the effect estimated for the real treated unit. Followingthis procedure, the p-values are computed for each test performed.

Table 1 provides, for each post-treatment year, the probability of getting a more extreme positive deviation from the synthetic control group than the deviation for the true treatment 
country (Figure $\mathrm{C} 1$ reports the corresponding graphs for each of these p-values). Overall, the placebo results indicate a high level of significance of the estimated effect of tax reform on the highest top income shares, meaning those in the upper half of the top decile or, most clearly, in the top percentile group. For Australia and Norway the outcome is strongly robust both in the short- and medium-run whereas effects in New Zealand are primarily significant in the short-term effect.

[Table 1 about here]

\section{Robustness and extensions}

We report in this section robustness tests of the main SCM analysis, difference-in-difference estimations on a cross-country panel dataset and, finally, estimations of the tax-reform effect on economic efficiency.

\subsection{Different control variables and placebo tests}

Two robustness checks of the main SCM results are presented here. ${ }^{12}$ The first reruns SCM analyses using 35 new combinations of controls when constructing synthetic control groups. There are many potential determinants of top income shares and of tax reforms in addition to those used in the baseline model and we here examine if these other control variables would give rise to substantially different results than our baseline. Panel a of Figure 6 shows that using different variables to construct the synthetic control does not invalidate our main findings. There are some alternative specifications, especially for New Zealand, that produce a synthetic control with a lower outcome, especially inflating the effect of the treatment. On the other hand, Norway is fitted very well. This may be due to the fact that the donor pool is composed of few Englishspeaking countries from which the synthetic control can be picked (only Canada and Ireland), whereas Norway has more potentially similar countries (Denmark, Finland, Netherlands, and Sweden).

The second robustness check is to make "in time" placebo tests, where we impose falsely timed tax reforms in the three studied countries ( 5 years before and after the actual reform). Panel $b$ shows that the "in-time" falsification exercise also reinforces the robustness of results. There are no significant negative (or positive) effect that can be compared with the true reform effect in all the cases. ${ }^{13}$

[Figure 6 about here]

\footnotetext{
${ }^{12}$ Appendix $\mathrm{C}$ presents extended variants of these tests along with a third sensitivity test: the scrutiny of posttreatment trends of the control variables in treated and synthetic control group countries in order to detect possible confounding effects of the post-treatment outcomes.

${ }^{13}$ In Figure C2 we show that there is one case, Norway 13 years before the reform (i.e., in 1978), where we encounter an evident tax-reform effect. However, when the placebo is handed out in 1981 and 1984 (respectively 10 and 8 years before the real treatment), this troubling effect vanishes and we chose to interpret it as a mass significance effect.
} 


\subsection{Panel regression estimates}

Panel regressions are run to complement the baseline SCM analysis and to allow us to examine how much of the progressivity effects is due to changes in tax rate progression over the income distribution versus cuts in top marginal tax rates. We use difference-in-difference estimation on variants of a basic log-linear equation:

$$
y_{i t}^{s}=\epsilon_{1}^{s} \tau_{i t}^{s}+\epsilon_{2}^{s} \Pi_{i t}+\beta_{1}^{s} \text { Reform } \text { for }_{i t}+\beta_{2}^{s} Z_{i t}+\gamma_{t}^{s}+\mu_{i}^{s}+\mu_{i}^{s} t^{s}+u_{i t}^{s}
$$

where $i$ and $t$ represents a country and a point in time respectively. $y_{i t}^{s}$ is the log share of total income owned by income fractile $s$ and we use either $\tau_{i t}^{s}$, the log of the net-of-tax rate, or $\Pi_{i t}$, the structural tax progressivity, to account for any of the two influences on top shares. Re form $m_{i t}$ is a dummy variable equal to one each post-reform year. We focus on the three studied reforms above but also run tests on all recorded tax reforms in our country sample. ${ }^{14}$ Lastly, $Z_{i, t}$ is a vector of the same controls as in the baseline SCM estimations, $\gamma_{t}^{s}$ is a time fixed effect and $\mu_{i}^{s}$ $+\mu_{i}^{s} t^{s}$ a country-specific fixed effect plus a country-specific linear time trend.

Note that several econometric issues arise here. Including both a measure of tax progressivity or top tax rates and a tax-reform dummy is potentially problematic due to the collinearity between these variables. Therefore we use them separately in almost all regression models with exception for two where we wish to study explicitly if there is a possible additional reform effect over and above the level of progressivity or top taxation. Another potential problem arises if the error term is correlated with measures of tax rate and progressivity due to reverse causality, leading to a biased towards zero parameter. On the other hand, each non-tax related factor affecting top incomes that is not captured by the vector of controls and the country and time fixed effects may give rise to an omitted variable bias, upward biasing $\beta_{1}^{s}$ and $\epsilon^{s}$. It is because of these problems that we view the panel regressions merely as complementary to the main SCM analysis.

Table 2 and 3 present the main regression results (additional regressions are presented in Appendix D) and two patterns stand out. The first is that regression coefficients indicate a positive association between tax reforms and top income shares, i.e., in line with the results of the main SCM analysis. The association is also stronger higher up in the income distribution, especially in the top percentile, and especially when we restrict the analysis to the reforms in the three treated countries. The top 0.1 percent increases between 66 and 137 percentage points whereas the SCM estimates an average effect of around 50 and 100. In the case of New Zealand, top incomes rose of about 59 percentage points for the top 0.5 , very close to the SCM estimation. On the other hand, we find modest or insignificant effects for the groups below the top percentile, as in the SCM estimations. The only exception is for New Zealand, where Table 2 reports an increase of 11 percent in the income share of the Top 10-1, whereas the

\footnotetext{
${ }^{14}$ Those other reforms are Canada 1982, Finland 1991, France 1986, Germany 2005, Ireland 1992, Italy 1989, Netherlands 1990, Spain 2007, Sweden 1991, UK 1988, and US 1987. See Appendix A4 for a description of such reforms.
} 
SCM displays insignificant effects for the bottom half of the top decile, but an average increase around 10 percent for the next four percentile.

[Table 2 about here]

Second, we find that top income shares respond more to reductions in top net-of-tax rates than to reductions in progressivity ${ }^{15}$. Table 3 shows that the effect of the reform is still significant even controlling for the progressivity level (panel a) or for the $M T R^{s}$ (panel b). However, the $\beta_{1}$ coefficient reduces of about one third, because part of the variation is absorbed by the progressivity or tax rate coefficient. Whereas tax rate and progressivity effects are insignificant for the share below the top percentile, the elasticity is positive and increasing for the groups above. Those findings suggest that the behavioral response of the top percentile is very different from the groups below. Table 3 shows that a tax rate cut of 1 percent increases the top 0.1 income share of 0.9 percent, while a similar cut in progressivity has a lower effect. On the other hand, no significant effects are found for the shares below the top percentile. In other words, the tax elasticity is not a constant along the income distribution. Alternative regressions (see Appendix D) show that the association appears to grow when we use the marginal tax rate-based measures than when we use average tax rate-based measures.

[Table 3 about here]

\subsection{Other reform effects: Broader base and fewer brackets}

Tax reforms often bring many changes to the tax system over and above new tax rate schedules adjusting the level and progression of tax rates over taxable income. For example, most of the 1980s tax reforms were associated with reductions in the number of tax brackets and broadening of tax bases. Accounting for these other dimensions can be important as they are likely to have a direct influence on top income earners and confound some of the measured effects in the main analysis.

Using data from the OECD Tax Database, we compute the number of brackets on wage income. As long as a higher number of tax brackets implies more progressivity, we expect a negative correlation between this indicator and top incomes, as in the case we used ARP and MRP indicators.

Kopczuk (2005) discusses the implications of tax base-broadening reforms. It might be important to account for the tax base effects, since differences in behavioral elasticity across countries may reflect different tax systems in place. We calculate the taxable income from the broad measure of income by subtracting deductions, exemptions, and accounting for the impact of tax credits at both central and sub-central levels. It can be defined:

\footnotetext{
${ }^{15}$ It is not possible to perfectly disentangle the two forces since they are connected, both in theory as they reflect the overall direction of tax policy and in their construction as the progressivity measures are based on information provided in tax schedules. Moreover, we interpret cautiously the coefficients from Table 3 when the dummy reform and the tax rate or the progressivity measure are used in the same regression because of the collinearity between these two variables.
} 


$$
\operatorname{TaxBase}_{i, t}=\left(\bar{Y}_{i, t}-\operatorname{NoTax}_{i, t}\right) / \bar{Y}_{i, t}
$$

as the share of average reported income $Y$ subject to taxation. NoTax $x_{i, t}$ takes into account of no-tax area (amount of income where the MTR applied is zero), basic/standard tax allowances and tax credits at both central and sub-central levels ${ }^{16}$. NoTax is not depended by the income share $s$, but it is the same for each share of the total income ${ }^{17}$. We retrieve data on average reported income from WID. ${ }^{18}$

Table 4 indicates that tax brackets are negatively correlated with top income shares, further reinforcing the previous findings on the relationship between tax progressivity and inequality. However, the correlation vanishes as we include the marginal tax rate in the regressions. Our measure of the tax base, on the other hand, is not significantly correlated with top incomes shares at all. Whether this indicates a true no-effect or if measurement problems are simply too large cannot be determined with the data at hand.

[Table 4 about here]

\subsection{Efficiency effects: Do tax reforms increase the size of the cake?}

Arguments about enhanced economic activity and efficiency were important behind the tax reforms of the 1980s (Auerbach and Slemrod, 1997; Gale and Samswick, 2014). This raises the questions whether our estimated results above reflect a redistribution of incomes from the bottom and middle to the top or if they are the result of new resources being generated by top income earners.

We examine this issue by running SCM estimations using as outcome variables three variables that reflect real economic activity: GDP per capita, growth of registered patents and total tax revenues as share of GDP. Country sample and control variables are the same as in the main analysis. These "efficiency variables" are, of course, not perfect. They are aggregate for the whole economy and not, as in the case of top income shares, able to distinguish between groups in the top of the income distribution. Furthermore, they capture both efficiency-related and other, not necessarily efficiency-related processes. The tests should therefore be interpreted with caution.

Figure 7 shows the results which indicate that none of the three efficiency variables are significantly affected by the tax reform treatments in any of the three studied countries. In the case of GDP per capita growth, there is a small difference in the post-treatment period levels, but a closer look indicates that this wedge actually occurred some year before or after the tax

\footnotetext{
${ }^{16}$ Such reliefs are universally available and are unrelated to expenditures incurred by taxpayers, and typically available as fixed amounts or some fixed percentage of income. When relief is provided in the form of a tapered tax credit, the maximum amount is applied.

${ }^{17}$ However, this measure of the tax base is not perfect, since many reliefs cannot be considered (for instance, tax avoidance and tax evasion, shifting from different tax bases, taxpayer-specific tax reliefs, etc.)

${ }^{18} \mathrm{~A}$ better measure would be the median income, but, unfortunately, such measure is not available.
} 
reform was implemented. Moreover, in New Zealand the control group has a markedly higher post-treatment growth, but this also appears before the reform date.

Taken together, we can reject strong real income responses to the progressivity reductions. At the same time, we found the strongest income share responses among the absolute top groups for which capital incomes are the most predominant income source. This suggests that the recorded inequality increases largely emanated from activities of tax planning and income shifting of capital income. This would go well in line with previous findings in other analyses of tax reforms, e.g., in Auerbach (1988), Slemrod (1996), Piketty et al. (2014) and Saez (2017).

[Figure 7 about here]

\section{Conclusions}

The question we set out to answer was how tax progressivity change affects the income distribution. While this question has been studied before, the unique contribution of our study is that we exploit tax reforms as source of progressivity variation and the synthetic control method for identifying the effects on top income shares. To our knowledge we are the first to approach the progressivity-inequality nexus in this way.

Our findings suggest that the reduced progressivity recorded during the tax reforms of the 1980s and early 1990s had strong and positive effects on the income shares of the very top of the distribution in all three countries studied. The effects appear to have lasted for a long time, at least ten years and perhaps as long as 25 years in the case of Australia. In contrast, we are unable to trace any significant income responses to the progressivity reforms in the lower parts of the top income decile. In fact, effects are relatively marginal in all top income groups below the highest income percentile.

The mechanisms behind this result are yet to be identified, but we make some tests allowing us to draw some tentative conclusions. First, we find that reduced top marginal tax rates can account for most of the recorded boost in top percentile income shares while the reduction in tax rate progression matters less. Second, changes in capital income among the very top groups appear to be an important part of the story behind the top share response. This indicates that tax avoidance behavior could matter, which confirms earlier case studies of tax reform responses. Third, and related, we cannot find any evidence on any real economic responses, e.g., increased labor supply or higher efficiency in general, to the progressivity reductions. An important disclaimer is that our mechanism analyses rest on less precise data and therefore needs to be interpreted with caution. This motivates future research to decompose the different components of the behavioral response to tax reform, improving our understanding of the relationship between taxation and inequality. 


\section{References}

Aaberge, R., A. B. Atkinson (2010). "Top incomes in Norway." in Atkinson, A. B. and T. Piketty (eds.) Top incomes over the Twentieth Century: A Global Perspective. Oxford: Oxford University Press.

Aarbu, K. O., T. O. Thoresen (1997). "The Norwegian tax reform: distributional effects and the high-income response.” Discussion Paper No. 207. Oslo: Statistics Norway.

Aarbu, K. O., T. O. Thoresen (2001). "Income responses to tax changes - evidence from the Norwegian tax reform." National Tax Journal: 319-335.

Abadie, A., A. Diamond, J. Hainmueller (2010). "Synthetic control methods for comparative case studies: Estimating the effect of California's Tobacco Control Program." Journal of the American Statistical Association 105(490): 493-505.

Abadie, A., A. Diamond, J. Hainmueller (2015). "Comparative politics and the synthetic control method." American Journal of Political Science 59(2): 495-510.

Adam, S., J. Browne, C. Heady (2010). "Taxation in the UK." In Dimension of Tax Design: the Mirrlees Review: 1-87.

Alstadsaeter, A., M. Jacob, W. Kopczuk and K. Telle (2016). ”Accounting for business income in measuring top income shares: Integrated accrual approach using individual and firm data from Norway.” NBER Working Paper No. 22888.

Alvaredo, F., A. B. Atkinson, T. Piketty, E. Saez, G. Zucman (2016). "The World Wealth and Income Database." http://www.wid.world, accessed on 04/02/2016.

Atkinson, A. B., A. Leigh (2007). "The distribution of top incomes in Australia." Economic Record 83(262): 247-261.

Atkinson, A. B., A. Leigh (2008). "Top incomes in New Zealand 1921-2005: Understanding the effects of marginal tax rates, migration threat, and the macroeconomy." Review of Income and Wealth 54(2): 149-165.

Atkinson, A. B., A. Leigh (2013). "The distribution of top incomes in five Anglo-Saxon countries over the long run." Economic Record 89(S1): 31-47.

Atkinson, A. B., T. Piketty (eds.) (2007). Top incomes in the United Kingdom over the Twentieth Century: A contrast between Continental European and English-Speaking Countries. Oxford: Oxford University Press.

Atkinson, A. B., T. Piketty, E. Saez (2011). "Top incomes in the long run of history.” Journal of Economic Literature 49: 3-71.

Andrew Young School of Policy Studies. (2010). "Andrew Young School World Tax Indicators (Volume 1) [Data file, data description, and data appendix]." Retrieved from http://aysps.gsu.edu/isp/wti.html

Auerbach, A. J. (1988). "Capital gains taxation in the United States." Brookings Papers on Economic Activity 2: 595-631.

Auerbach, A. J., J. Slemrod (1997). "The economic effects of the Tax Reform Act of 1986." Journal of Economic Literature 35(2): 589-632.

Australian Government (1985). "Reform of the Australian Tax System: Draft White Paper." Australia Government Publishing Service. Canberra. 
Bach, S., G. Corneo, V. Steiner (2013). "Effective taxation of top incomes in Germany." German Economic Review 14(2): 115-137.

Bengtsson, N., B. Holmlund, D. Waldenström (2016). 'Lifetime versus annual tax and transfer progressivity: Sweden, 1968-2009." Scandinavian Journal of Economics 118(4): 619-645.

Brewer, M., E. Saez, A. Shephard (2010). "Means-testing and tax rates on earnings." in Mirrlees, J. (ed.), Dimension of Tax Design: The Mirrlees Review. London: Institute for Fiscal Studies. Oxford and New York: Oxford University Press.

Brys, B., S. Matthews, J. Owens (2011). "Tax reform trends in OECD countries." OECD Taxation Working Papers No. 1. OECD Publishing, Paris.

Burkhauser, R. V., M. H. Hahn, R. Wilkins (2015). "Measuring top incomes using tax record data: A cautionary tale from Australia." Journal of Economic Inequality 13(2): 181-205.

Doerrenberg, P., A. Peichl (2014). "The impact of redistributive policies on inequality in OECD countries." Applied Economics 46(17): 2066-2086.

Duncan, D., K. Sabirianova Peter (2016). "Unequal inequalities: Do progressive taxes reduce income inequality?" International Tax and Public Finance 23(4): 762-783.

Evans, L., A. Grimes, B. Wilkinson, D. Teece (1996). "Economic reform in New Zealand 1984-95: The pursuit of efficiency." Journal of Economic Literature 34(4): 1856-1902.

Feenberg, D. R., J. M. Poterba (1993). "Income inequality and the incomes of very high-income taxpayers: evidence from tax returns." in Poterba, J. M. (ed.), Tax Policy and the Economy 7: $145-177$.

Feldstein, M. (1995). "The effect of marginal tax rates on taxable income: A panel study of the 1986 Tax Reform Act.” Journal of Political Economy 103: 551-572.

Feldstein, M. (1999). "Tax avoidance and the deadweight loss of the income tax." Review of Economics and Statistics 81(4): 674-680.

Fjærli, E., R. Aaberge (2000). "Tax reforms, dividend policy and trends in income inequality: Empirical evidence based on Norwegian data.” Discussion Paper No. 284. Oslo: Statistics Norway.

Förster, M., A. Llena-Nozal, V. Nafilyan (2014). "Trends in top incomes and their taxation in OECD countries". OECD Social, Employment and Migration Working Papers No. 159. OECD Publishing: Paris.

Frey, C., C. A. Schaltegger (2016). "Progressive taxes and top income shares: A historical perspective on pre-and post-tax income concentration in Switzerland." Economics Letters 148: 5-9.

Gale, W. G., A. A. Samwick (2014). "Effects of income tax changes on economic growth." The Brookings Institution.

Gruber, J., E. Saez (2002). "The elasticity of taxable income: evidence and implications." Journal of Public Economics 84(1): 1-32.

Kopczuk, W. (2005). "Tax bases, tax rates and the elasticity of reported income." Journal of Public Economics 89(11): 2093-2119.

Keating, P. (1985). "Reform of the Australian taxation system: Statement by the treasurer." Australian Government Publishing Service No. 315. Canberra. 
Leigh, A. (2009). “Top incomes.” in Salverda, W., B. Nolan, T. Smeeding (eds.), The Oxford Handbook of Economic Inequality. Oxford: Oxford University Press.

The Maddison-Project, http://www.ggdc.net/maddison/maddison-project/home.html, 2013 version.

Musgrave, R., T. Thin (1948). "Income tax progression, 1929-48." Journal of Political Economy 56(6): 498-514.

OECD (2014). Explanatory Annex. Part I. Taxation of wage income. http://www.oecd.org/ctp/taxpolicy/Personal-Income-Tax-rates-Explanatory-Annex-2014.pdf

OECD (2016a). Explanatory Annex: http://www.oecd.org/ctp/tax-policy/Personal-Income-Taxrates-Explanatory-Annex-May-2016.pdf

OECD (2016b). Tax revenue (indicator). doi: 10.1787/d98b8cf5-en (Accessed Feb. 2016)

Piketty, T., E. Saez (2007). "How progressive is the U.S. Federal Tax System? A historical and international perspective." Journal of Economic Perspectives 21(1): 3-24.

Piketty, T., Saez, E., Stantcheva, S. (2014). "Optimal taxation of top labor incomes: a tale of three elasticites.” American Economic Journal: Economic Policy 6(1): 230-271.

Reinhart, C. M., K.S. Rogoff (2011). "From financial crash to debt crisis." American Economic Review 101(5); 1676-1706.

Roine, J., J. Vlachos, D. Waldenström (2009). "The long-run determinants of inequality: What can we learn from top income data?" Journal of Public Economics 93(7): 974-988.

Roine, J., D. Waldenström (2015). "Long-run trends in the distribution of income and wealth." in Atkinson, A.B., F. Bourguignon (eds.), Handbook of Income Distribution, vol. 2A, Amsterdam: North-Holland.

Saez, E. (2004). "Reported incomes and marginal tax rates, 1960-2000: evidence and policy implications." Tax Policy and the Economy 18: 117-174.

Saez, E. (2017). "Taxing the rich more: Preliminary evidence from the 2013 Tax Increase", Tax Policy and the Economy 31, forthcoming.

Saez, E., J. Slemrod, S. H. Giertz (2012). "The elasticity of taxable income with respect to marginal tax rates: A critical review." Journal of Economic Literature: 3-50.

Slemrod, J. (1996). "High income families and the tax changes of the 1980s: the anatomy of behavioral response." in Feldstein M. and J. Poterba (eds.), Empirical Foundations of Household Taxation. University of Chicago.

Slemrod, J., J. Bakija (2000). "Does growing inequality reduce tax progressivity? Should it?." NBER Working Paper No. 7576. 
Figure 1: Values of $\Omega_{i, t}$ for PIT reforms since 1981

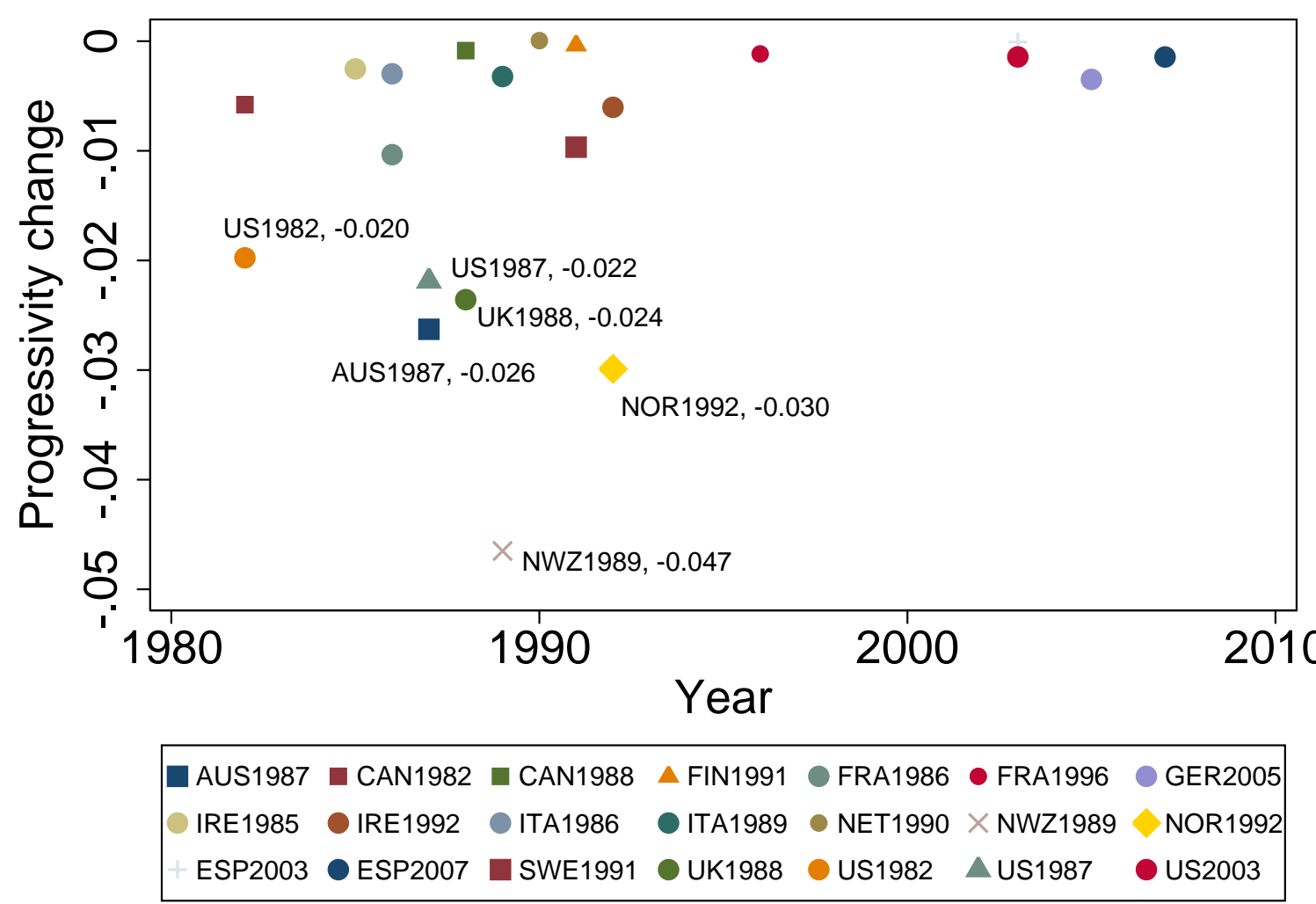

Note: each point in this figure represents the negative variation in the ARP over the middle-top income interval after a tax reform. $\Omega_{i, t}=A R P_{i, t_{1}}-A R P_{i, t_{0}}$. It is the difference in the ARP between the post-reform period $t_{1}$ and the pre-reform period $t_{0}$ for country i. It measures the variation in structural progressivity for each important reform from 1981 to 2010 for 18 countries. A more negative value of $\Omega_{i, t}$ indicates a larger reduction in structural progressivity. For the countries marked with * (Finland, Germany, and Sweden), the ARP is derived computing the ATR faced by an earner whose income is equal to 4 time GDP per-capita and an earner whose income is equal to GDP per-capita. Data for ATRs are calculated from OECD Tax Database schedules. Top income series are from WID source. GDP per-capita is from The Maddison-Project. $\Omega$ values can be found in table A5. 
Figure 2: Comparison between top percentile, top MTR and ARP in selected countries

a) Top 1 vs $M T R^{\text {top }}$
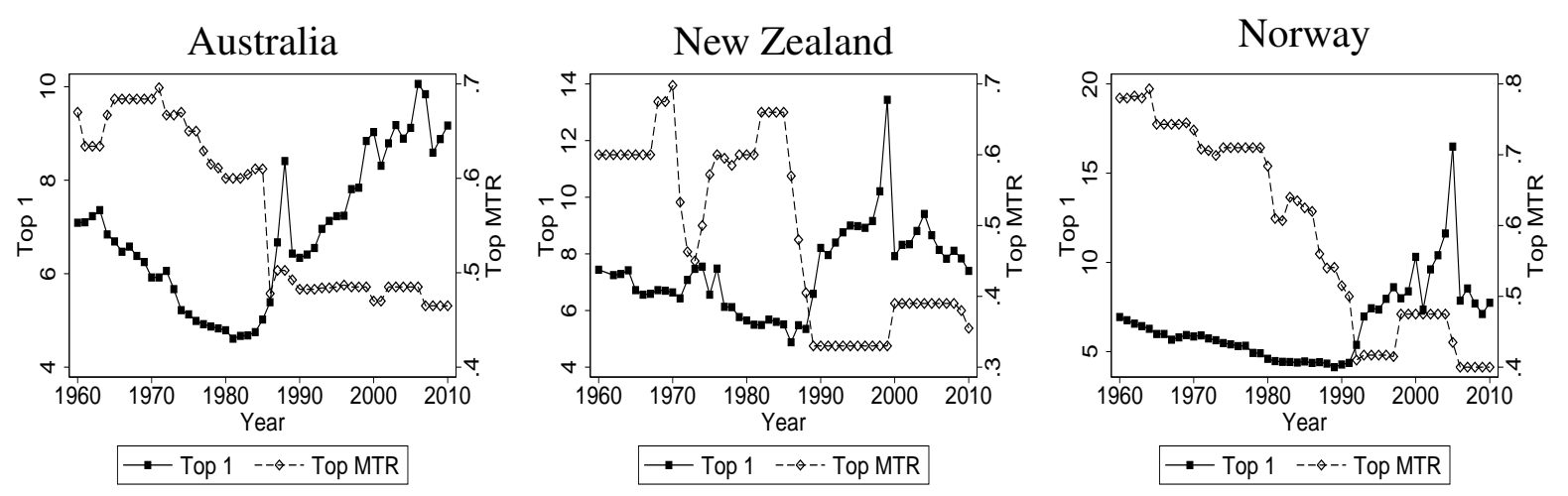

b) Top 1 vs $A R P$
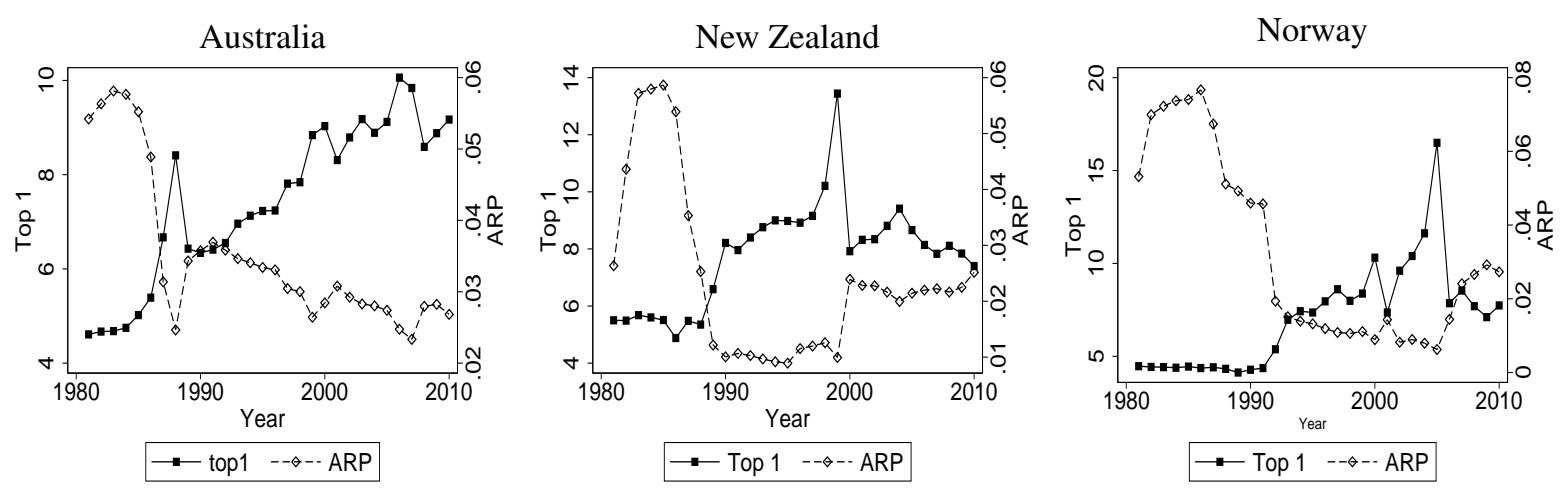

Note: Figure a) displays the evolution of top percentile (source: WID) and top MTR (source: Piketty et al., 2014) in Australia, New Zealand, and Norway.

Figure b) compares series on ARP (source: authors' computation) and top percentile over the period 1981-2010. 
Figure 3: Australian tax reform

\section{a) Top income shares}

Top 10

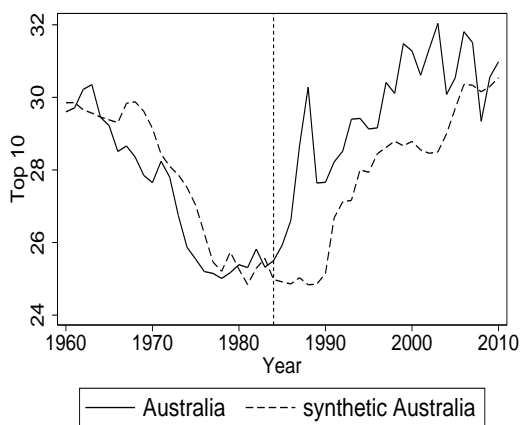

Top 1

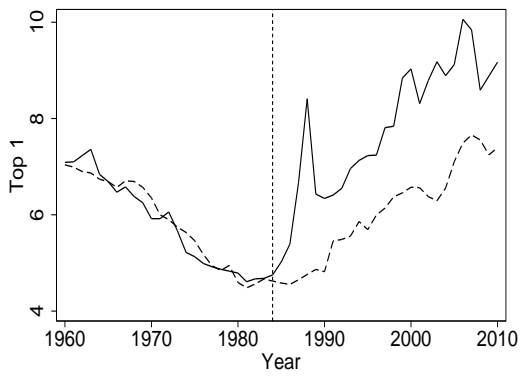

Australia --.-- synthetic Australia
Top 0.1

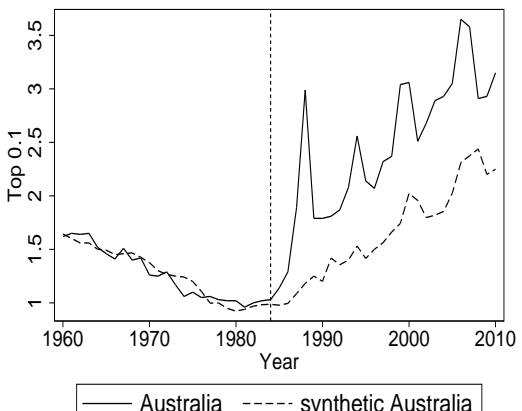

Australia --.-. synthetic Australia

b) Intermediate income shares

Top 5-1

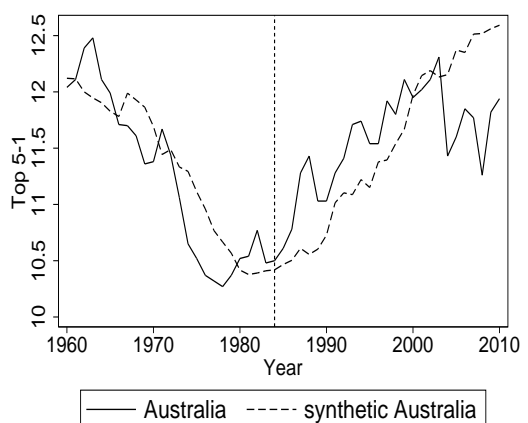

Top 1-0.5

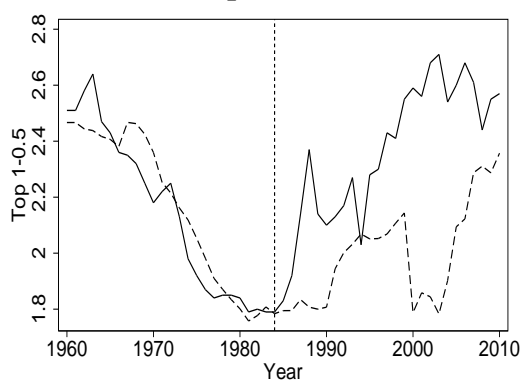

_- Australia ----- synthetic Australia
Top $0.5-0.1$

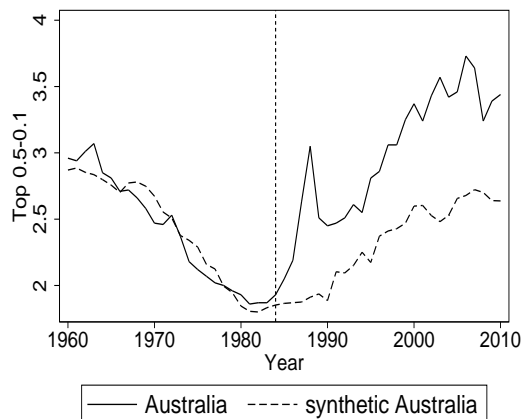

Note: For each top income share, a synthetic control group (dashed line) is calibrated to match the true trend (solid line) prior to treatment. The trend of the synthetic control represents the trend in Australia in absence of the tax reform, and the difference between the two lines is the effect of tax reform on the top income shares. The vertical dashed line (representing the year in which the reform was announced) splits the full time-period (1960-2010) in pre- and post-reform period. 
Figure 4: New Zealand's tax reform

a) Top income shares

Top 10

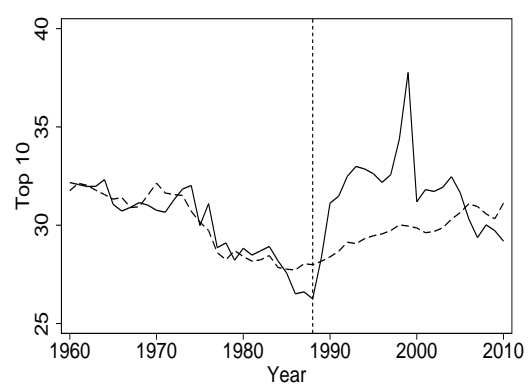

- New Zealand ----- synthetic New Zealand
Top 1

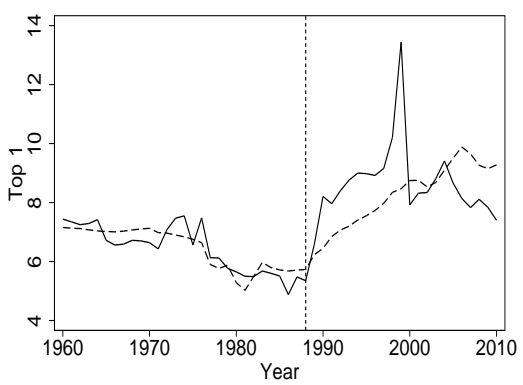

- New Zealand ----- synthetic New Zealand

b) Intermediate income shares

Top 10-5

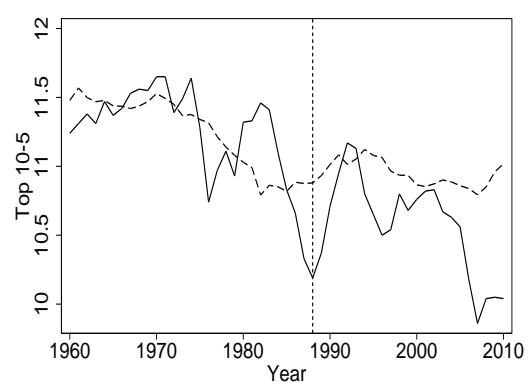

_ New Zealand ------ synthetic New Zealand
Top 5-1

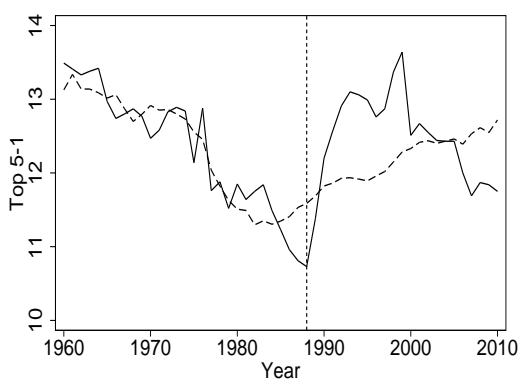

New Zealand ----- synthetic New Zealand
Top 0.5

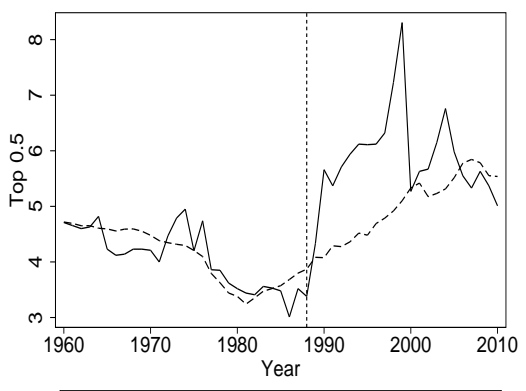

- New Zealand ----- synthetic New Zealand

Top 1-0.5

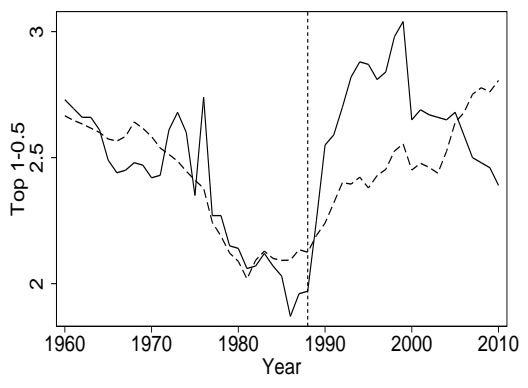

-- synthetic New Zealand

Note: See figure 3 for details. 
Figure 5: Norwegian tax reform

\section{a) Top income shares}

Top 10

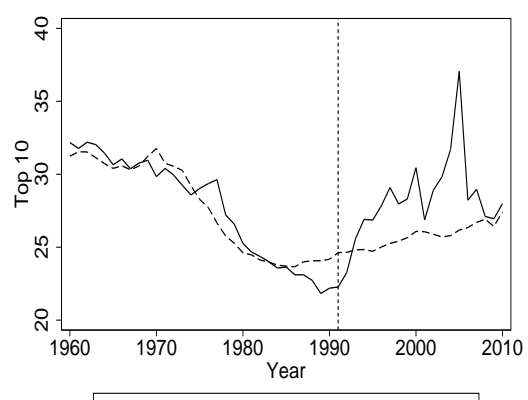

_- Norway ----- synthetic Norway
Top 1

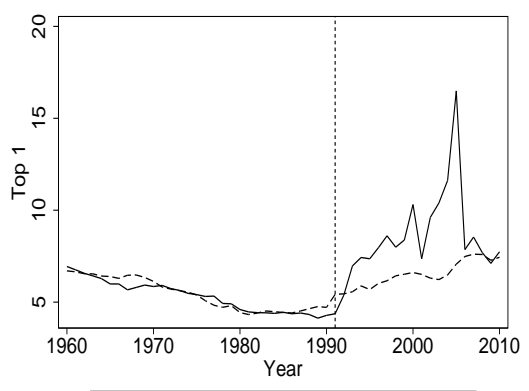

_ Norway ----- synthetic Norway

b) Intermediate income shares

Top 10-5

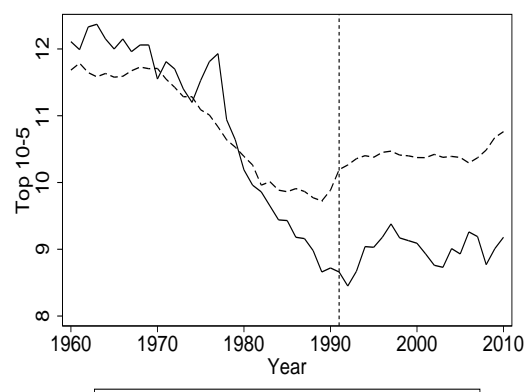

- Norway -----. synthetic Norway
Top 1-0.5

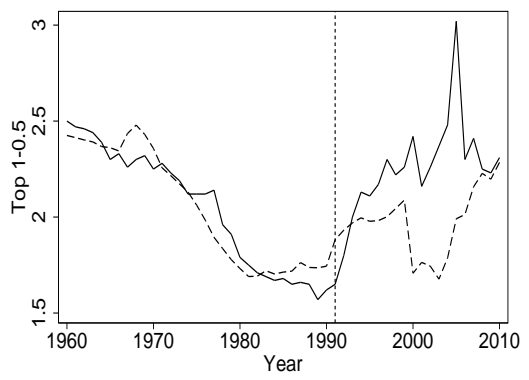

— Norway ----- synthetic Norway
Top 0.1

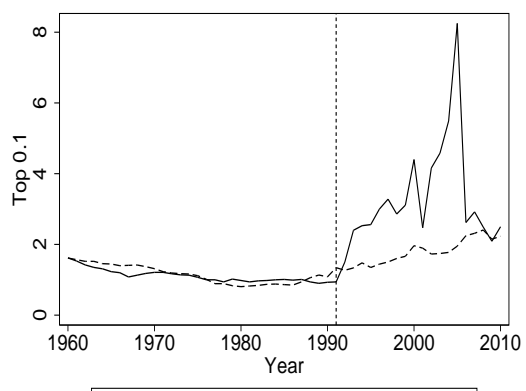

— Norway ----- synthetic Norway

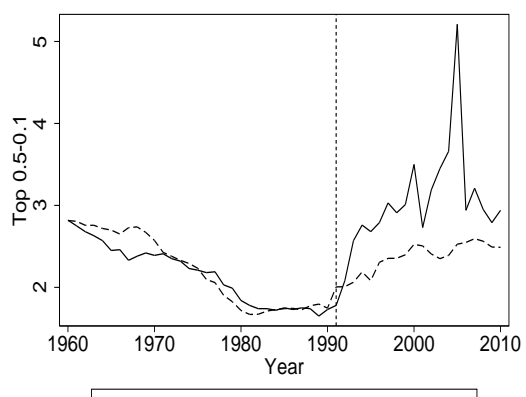

_- Norway -----. synthetic Norway

Note: See figure 3 for details. 
Figure 6: Robustness of the main SCM results

a) Test of control variables

Australia

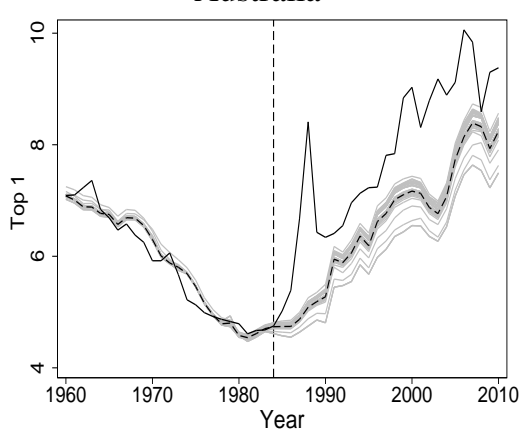

Australia: - 5 years

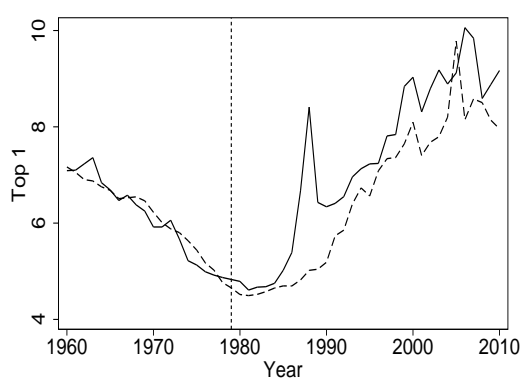

- Australia ----- synthetic Australia

Australia: +5 years

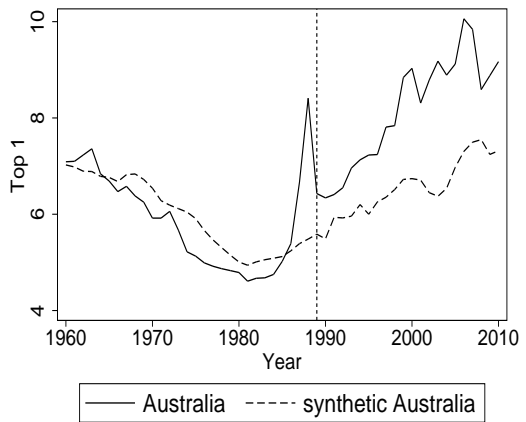

New Zealand

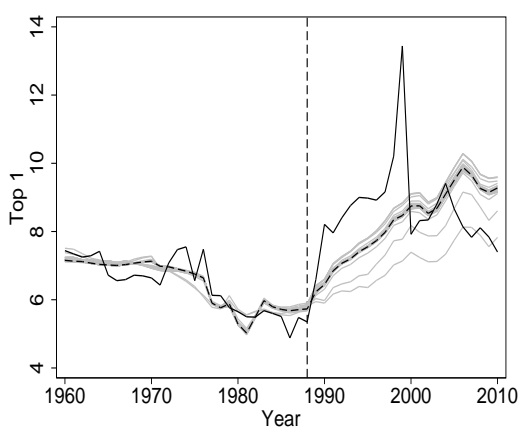

b) "In-time" placebo test New Zealand: - 5 years

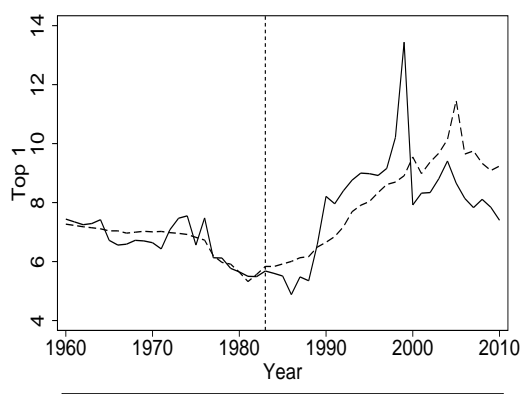

- New Zealand -----. synthetic New Zealand

New Zealand: +5 years

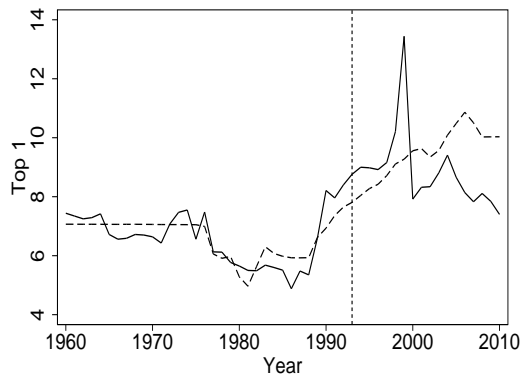

- New Zealand -----. synthetic New Zealand
Norway

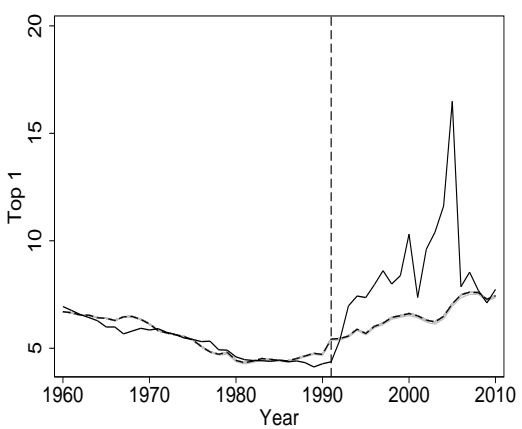

Norway: - 5 years

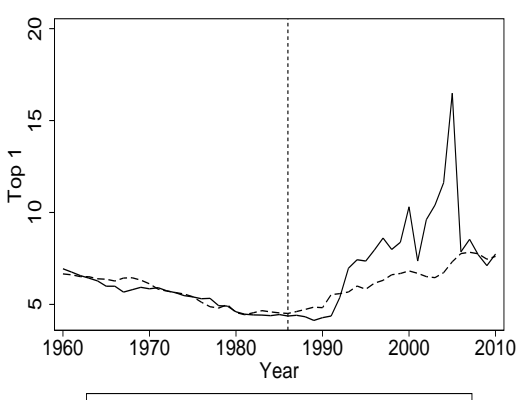

Norway: +5 years

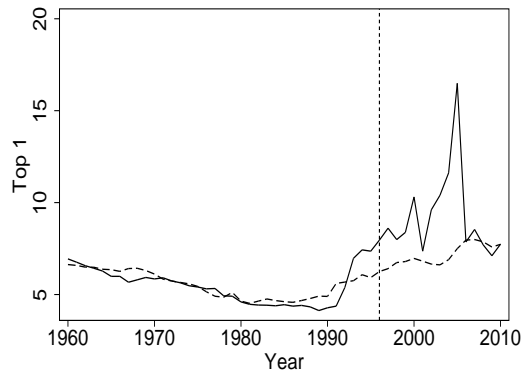

Norway ----- synthetic Norway

Note: Panel a) tests whether the outcome is sensitive to the choice of the vector of controls. The black solid line is the true trend of the top percentile in the treated country. The dash line is the synthetic control group trend calculated from the baseline set of control variables, and each grey line represents the synthetic control group obtained with a different set of controls. This robustness test is based on 35 different combinations of variables, combined with three different set of years used to control for the top income trends. Altogether, there are 105 different combinations and, thus, the same number of potentially different synthetic control for each country. In the figure there are less than 105 lines: this is because the SCM assigns a very small weight to some variable and, thus, the resulting optimization problem is basically identical to the baseline model. Each combination of controls tested is presented in Appendix C2, whereas the controls are described in Appendix A3. Panel b) imposes falsely timed tax reforms in the three studied countries 5 years before ( -5 years) and after ( +5 years) the actual reform. An extended version of this test can be found in Appendix C3. 
Figure 7: Efficiency effects of tax reforms

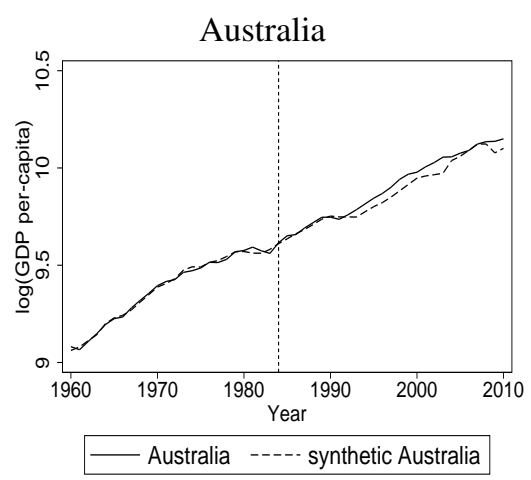

a) GDP per-capita growth rate
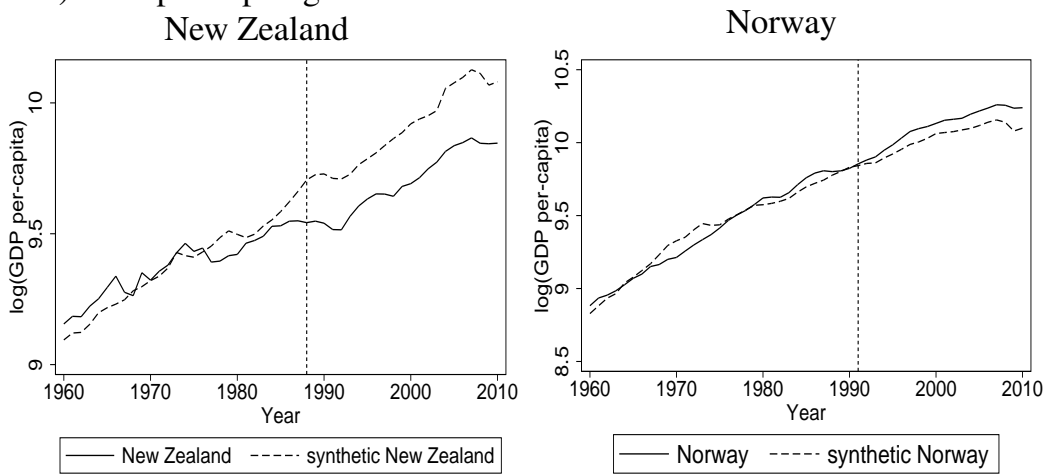

b) Annual growth rate in number of patents

Australia

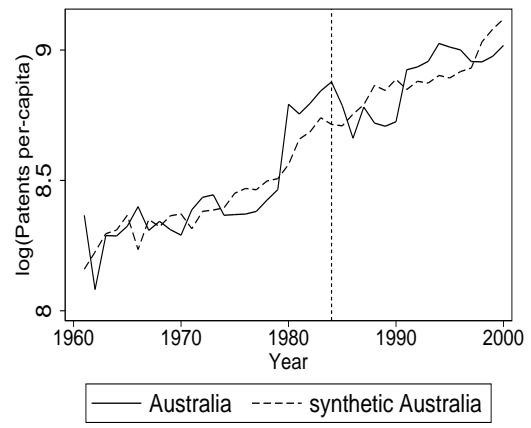

Australia

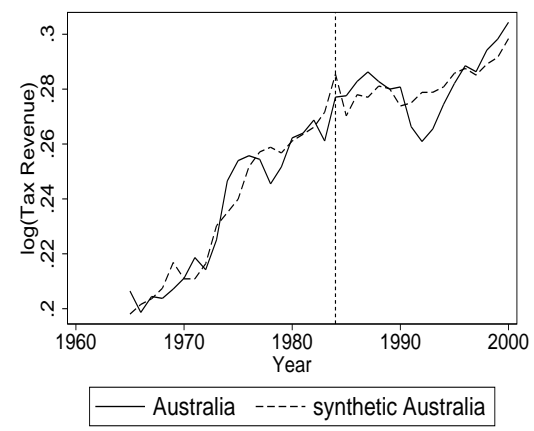

New Zealand

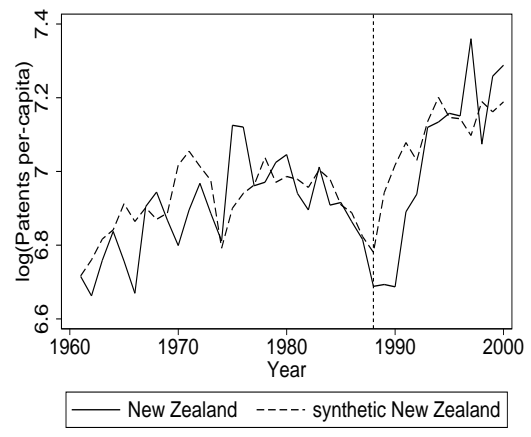

c) Tax revenues (percent of GDP) New Zealand

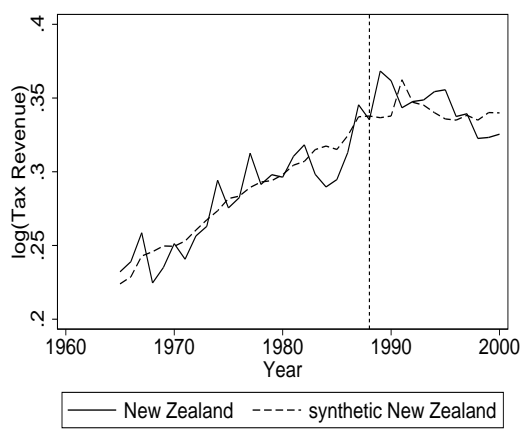

Norway

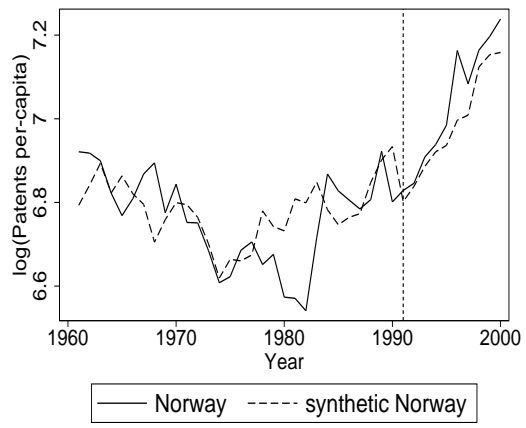

Norway

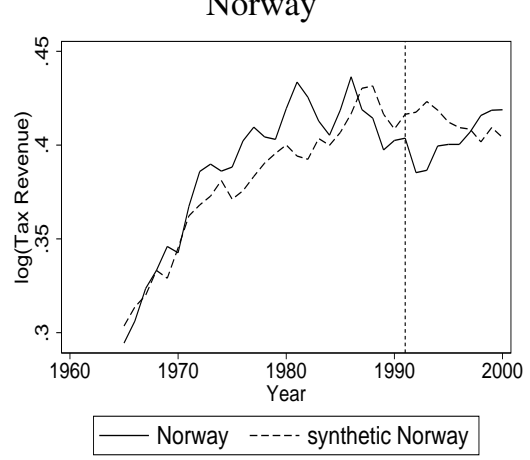

Note: This figure shows the effect of the tax reforms analyzed using the SCM method. Outcomes are a) the annual growth rate of GDP, b) number of registered patents per capita and c) total tax revenues as share of GDP. A synthetic control group (dashed line) is calibrated to match the true trend (solid line) prior the reform. The vertical dashed line (representing the year in which the reform was announced) splits the full time-period (1960-2010) in pre- and post-reform period. Data on patents are from Roine et al. (2009), whereas data on GDP per-capita are from the Madison Project, version 2013. Data on tax revenue are from OECD. Tax revenue (share of GDP) is defined as the revenues collected from taxes on income and profits, social security contributions, taxes levied on goods and services, payroll taxes, taxes on the ownership and transfer of property, and other taxes. This indicator relates to government as a whole (all government levels). 
Table 1: Statistical significance according to "in space" placebo test

\begin{tabular}{|c|c|c|c|c|c|c|c|c|c|}
\hline & \multicolumn{3}{|c|}{ a) Australia } & \multicolumn{3}{|c|}{ b) New Zealand } & \multicolumn{3}{|c|}{ c) Norway } \\
\hline Year & Top 5-1 & Top 1-0.5 & Top 0.1 & Top 10-5 & Top 1-0.5 & Top 0.5 & Top 10-5 & Top 1-0.5 & Top 0.1 \\
\hline 1985 & 0.4 & 0.27 & 0.11 & & & & & & \\
\hline 1986 & 0.3 & 0.09 & 0.11 & & & & & & \\
\hline 1987 & 0.1 & 0.09 & $<0.01$ & & & & & & \\
\hline 1988 & 0.2 & $<0.01$ & $<0.01$ & & & & & & \\
\hline 1989 & 0.3 & 0.09 & $<0.01$ & 0.8 & 0.2 & 0.1 & & & \\
\hline 1990 & 0.3 & 0.09 & $<0.01$ & 0.9 & $<0.01$ & $<0.01$ & & & \\
\hline 1991 & 0.3 & 0.09 & $<0.01$ & 0.5 & $<0.01$ & $<0.01$ & & & \\
\hline 1992 & 0.3 & 0.18 & $<0.01$ & 0.1 & 0.1 & $<0.01$ & 0.91 & 0.45 & $<0.01$ \\
\hline 1993 & 0.1 & $<0.01$ & $<0.01$ & 0.4 & $<0.01$ & $<0.01$ & 0.91 & 0.27 & $<0.01$ \\
\hline 1994 & 0.3 & 0.18 & $<0.01$ & 0.5 & $<0.01$ & $<0.01$ & 0.91 & 0.18 & $<0.01$ \\
\hline 1995 & 0.3 & 0.09 & $<0.01$ & 0.6 & $<0.01$ & $<0.01$ & 0.91 & 0.18 & $<0.01$ \\
\hline 1996 & 0.3 & 0.18 & $<0.01$ & 0.7 & 0.1 & $<0.01$ & 0.91 & 0.18 & $<0.01$ \\
\hline 1997 & 0.3 & $<0.01$ & $<0.01$ & 0.5 & 0.1 & $<0.01$ & 0.91 & 0.18 & $<0.01$ \\
\hline 1998 & 0.3 & $<0.01$ & $<0.01$ & 0.4 & 0.1 & $<0.01$ & 0.91 & 0.18 & $<0.01$ \\
\hline 1999 & 0.3 & $<0.01$ & $<0.01$ & 0.6 & $<0.01$ & $<0.01$ & 0.91 & 0.18 & $<0.01$ \\
\hline 2000 & 0.3 & $<0.01$ & $<0.01$ & 0.4 & 0.2 & 0.3 & 0.82 & $<0.01$ & $<0.01$ \\
\hline 2001 & 0.3 & $<0.01$ & $<0.01$ & 0.3 & 0.2 & 0.3 & 0.82 & 0.09 & $<0.01$ \\
\hline 2002 & 0.3 & $<0.01$ & $<0.01$ & 0.3 & 0.3 & 0.2 & 0.82 & $<0.01$ & $<0.01$ \\
\hline 2003 & 0.3 & $<0.01$ & $<0.01$ & 0.4 & 0.3 & 0.1 & 0.82 & $<0.01$ & $<0.01$ \\
\hline 2004 & 0.4 & $<0.01$ & $<0.01$ & 0.4 & 0.3 & $<0.01$ & 0.82 & $<0.01$ & $<0.01$ \\
\hline 2005 & 0.5 & $<0.01$ & $<0.01$ & 0.5 & 0.3 & 0.1 & 0.82 & $<0.01$ & $<0.01$ \\
\hline 2006 & 0.5 & $<0.01$ & $<0.01$ & 0.5 & 0.5 & 0.2 & 0.82 & 0.27 & 0.22 \\
\hline 2007 & 0.5 & 0.27 & $<0.01$ & 0.6 & 0.6 & 0.3 & 0.82 & 0.27 & $<0.01$ \\
\hline 2008 & 0.6 & 0.36 & $<0.01$ & 0.7 & 0.7 & 0.2 & 0.82 & 0.36 & 0.22 \\
\hline 2009 & 0.6 & 0.36 & $<0.01$ & 0.7 & 0.6 & 0.2 & 0.82 & 0.36 & 0.33 \\
\hline 2010 & 0.6 & 0.36 & $<0.01$ & 0.7 & 0.7 & 0.3 & 0.82 & 0.36 & $<0.01$ \\
\hline
\end{tabular}

Note: this table shows, for each post-treatment year, the probability of getting a more extreme positive deviation from the synthetic control group than the deviation for the true treatment country. It relates to the graphs in figure $\mathrm{C} 1$, as the number represents the share of grey lines that are higher than the black line for each post-treatment year. The population consists of the donor pool population for each top income share (all country with 0 or a positive weight in tables B1, B2, and B3). Countries with bad pre-treatment fit are ruled out as suggested by Abadie et al. (2010). 
Table 2: Regression estimations with dummy reform

i) Top 10-1

\begin{tabular}{l|cc|ccc} 
& a) Panel data & b) Time-series & \\
\hline & All reforms & Only "significant" reforms & AUS 1987 & NWZ 1989 & NOR 1992 \\
\hline Reform & $0.027^{*}$ & $0.047^{* *}$ & $0.016^{*}$ & $0.107^{* * *}$ & 0.041 \\
& $(0.015)$ & $(0.024)$ & $(0.009)$ & $(0.011)$ & $(0.051)$ \\
Obs. & 713 & 713 & 51 & 50 & 51 \\
\hline \hline
\end{tabular}

ii) Top 1-0.1

\begin{tabular}{l|cc|ccc} 
& a) Panel data & b) Time-series & \\
\hline & All reforms & Only "significant" reforms & AUS 1987 & NWZ 1989 & NOR 1992 \\
\hline Reform & $0.132^{* * *}$ & $0.259^{* * *}$ & $0.148^{* * *}$ & $0.286^{* * *}$ & 0.298 \\
& $(0.03)$ & $(0.042)$ & $(0.037)$ & $(0.042)$ & $(0.179)$ \\
Obs. & 713 & 713 & 51 & 49 & 51 \\
\hline \hline
\end{tabular}

iii) Top 0.1

\begin{tabular}{l|cc|ccc} 
& a) Panel data & b) Time-series & \\
\hline & All reforms & Only "significant" reforms & AUS 1987 & NWZ 1989 & NOR 1992 \\
\hline Reform & $0.286^{* * *}$ & $0.689^{* * *}$ & $0.505^{* * *}$ & $0.462^{* * *}$ & $0.862^{* *}$ \\
& $(0.071)$ & $(0.108)$ & $(0.072)$ & $(0.072)$ & $(0.42)$ \\
Obs. & 598 & 598 & 51 & 49 & 51 \\
\hline \hline
\end{tabular}

Note: Panel a) shows $\beta_{1}^{s}$ coefficients from panel regressions of the form: $y_{i, t}^{s}=\beta_{1}^{s} \operatorname{Reform} m_{i, t}+\beta_{2}^{s} Z_{i, t}+$ $\gamma_{t}^{s}+\mu_{i}^{s}+\mu_{i}^{s} t^{s}+u_{i, t}^{s}$. The time period is 1960-2010. In addition to the studied "Significant Reforms" of Australia 1987, New Zealand 1988, and Norway 1992, " All Reforms" include the reforms implemented in Canada 1982, Finland 1991, France 1986, Germany 2005, Ireland 1992, Italy 1989, Netherlands 1990, Spain 2007, Sweden 1991, UK 1988, and US 1987. Panel b) shows $\beta_{1}^{s}$ coefficients from time-series regressions of the form: $y_{t}^{s}=\beta_{1}^{s}$ Re form or $_{t}+\beta_{2}^{s} Z_{t}+\beta_{3} t^{s}+u_{t}^{s}$. In the case of New Zealand, we replace data on top 1-0.1 and top 0.1 with top 1-0.5 and top 0.5 since data on top 0.1 is missing. Newey-West standard errors with 8 lags in parenthesis. The controls are the same used in SCM estimations. Top income shares from WID. 
Table 3: Tax rate vs progressivity effects

\begin{tabular}{|c|c|c|c|c|c|c|c|c|}
\hline \multicolumn{9}{|c|}{ i) Top 10-1 } \\
\hline Reform & $\begin{array}{l}0.013 \\
(0.01)\end{array}$ & & & $\begin{array}{l}0.023^{*} \\
(0.014)\end{array}$ & & & $\begin{array}{c}0.008 \\
(0.018)\end{array}$ & \\
\hline Sig. Reform & & $\begin{array}{c}0.029 * * * \\
(0.016)\end{array}$ & & & $\begin{array}{c}0.036 * * \\
(0.018)\end{array}$ & & & $\begin{array}{c}0.042 * * \\
(0.002)\end{array}$ \\
\hline Rate Prog. & & & $\begin{array}{l}-0.005 \\
(0.012)\end{array}$ & $\begin{array}{c}0.009 \\
(0.014)\end{array}$ & $\begin{array}{c}0.009 \\
(0.011)\end{array}$ & & & \\
\hline $1-M T R$ & & & & & & $\begin{array}{l}-0.006 \\
(0.022)\end{array}$ & $\begin{array}{l}-0.015 \\
(0.033)\end{array}$ & $\begin{array}{l}-0.009 \\
(0.029)\end{array}$ \\
\hline \multicolumn{9}{|c|}{ ii) Top 1-0.1 } \\
\hline Reform & $\begin{array}{c}0.118 * * * \\
(0.029)\end{array}$ & & & $\begin{array}{c}0.096 * * * \\
(0.034)\end{array}$ & & & $\begin{array}{l}0.069^{*} \\
(0.038)\end{array}$ & \\
\hline Sig. Reform & & $\begin{array}{c}0.248 * * * \\
(0.045)\end{array}$ & & & $\begin{array}{c}0.098 \\
(0.061)\end{array}$ & & & $\begin{array}{c}0.215^{* * *} * \\
(0.051)\end{array}$ \\
\hline Rate Prog. & & & $\begin{array}{c}-0.169 * * * \\
(0.027)\end{array}$ & $\begin{array}{c}-0.112^{* * *} \\
(0.03)\end{array}$ & $\begin{array}{c}-0.131 * * * \\
(0.035)\end{array}$ & & & \\
\hline $1-M T R$ & & & & & & $\begin{array}{c}0.226 * * * \\
(0.059)\end{array}$ & $\begin{array}{c}0.159 * * \\
(0.065)\end{array}$ & $\begin{array}{l}0.109 * \\
(0.063)\end{array}$ \\
\hline \multicolumn{9}{|c|}{ iii) Top 0.1} \\
\hline Reform & $\begin{array}{c}0.313 * * * \\
(0.077)\end{array}$ & & & $\begin{array}{c}0.251 * * \\
(0.103)\end{array}$ & & & $\begin{array}{c}0.22 * * * \\
(0.075)\end{array}$ & \\
\hline Sig. Reform & & $\begin{array}{c}0.703 * * * \\
(0.112)\end{array}$ & & & $\begin{array}{c}0.473 * * * \\
(0.117)\end{array}$ & & & $\begin{array}{c}0.507 * * * \\
(0.08)\end{array}$ \\
\hline Rate Prog. & & & $\begin{array}{c}-0.336^{* * *} * \\
(0.091)\end{array}$ & $\begin{array}{c}-0.161 * \\
(0.097)\end{array}$ & $\begin{array}{c}-0.185^{*} \\
(0.102)\end{array}$ & & & \\
\hline $1-M T R$ & & & & & & $\begin{array}{c}0.909 * * * \\
(0.172)\end{array}$ & $\begin{array}{c}0.731 * * * \\
(0.166)\end{array}$ & $\begin{array}{c}0.654 * * * \\
(0.165)\end{array}$ \\
\hline
\end{tabular}

Note: This table shows $\epsilon_{1}^{s}, \epsilon_{2}^{s}$ and $\beta_{1}^{s}$ coefficients from log-linear equations of the form: $y_{i, t}^{s}=\epsilon_{1}^{s} \tau_{i, t}^{s}+\epsilon_{2}^{s} \Pi_{i, t}+$ $\beta_{1}^{s}$ Re form fort $_{i}+\beta_{2}^{s} Z_{i, t}+\gamma_{t}^{s}+\mu_{i}^{s}+\mu_{i}^{s} t^{s}+u_{i, t}^{s}$ where Reform is a dummmy variable equal to one each post-reform period. Differently from Table 2 , we estimate the model only for the period starting from 1981. The rate of Progressivity used is the MRP. We use the ARP in alternative estimation in Appendix D. Number of observations are 377, 377, and 304 for top 10-1, top 1-0.1, and top 0.1 respectively using progressivity, while they are 349, 319, and 306 for top $10-1$, top 1-0.1, and top 0.1 respectively using marginal tax rates. Newey-West standard errors with 8 lags in parenthesis. The controls are the same used in SCM estimations. $M T R^{s}$ are authors computations from OECD Tax Database. MRP are from Andrew Young School of Policy Studies (2010). Top income shares from WID. 
Table 4: Other dimensions of tax reform, 1981-2010

\begin{tabular}{|c|c|c|c|c|c|c|}
\hline & i) $\mathrm{T}$ & bracke & and top in & mes & & \\
\hline & Top & $0-1$ & Top & -0.1 & To & \\
\hline Tax Brackets & $\begin{array}{c}0.005 \\
(0.006)\end{array}$ & $\begin{array}{c}0.008 \\
(0.009)\end{array}$ & $\begin{array}{c}-0.062 * * * \\
(0.017)\end{array}$ & $\begin{array}{c}0.013 \\
(0.021)\end{array}$ & $\begin{array}{c}-0.151 * * * \\
(0.038)\end{array}$ & $\begin{array}{l}-0.002 \\
(0.058)\end{array}$ \\
\hline $1-M T R^{s}$ & & 0.004 & & $0.247 * * *$ & & $0.9 * * *$ \\
\hline & & $(0.026)$ & & $(0.08)$ & & $(0.261)$ \\
\hline Obs. & 430 & 347 & 430 & 317 & 337 & 304 \\
\hline
\end{tabular}

\begin{tabular}{l|cc|cc|cc}
\hline \hline \multicolumn{1}{|c|}{ ii) Tax base and top incomes } & \multicolumn{2}{c}{ Top 0.1 } \\
\hline Tax Base & \multicolumn{2}{|c|}{ Top 10-1 } & \multicolumn{2}{c|}{ Top 1-0.1 } & \multicolumn{2}{c}{0.195} \\
& $(0.032$ & -0.041 & 0.069 & 0.049 & -0.269 & -0.195 \\
$1-M T R^{s}$ & & $(0.043)$ & $(0.109)$ & $(0.086)$ & $(0.331)$ & $(0.265)$ \\
& & -0.004 & & $0.236^{* * *}$ & & $0.929 * * *$ \\
& & $(0.023)$ & & $(0.062)$ & & $(0.168)$ \\
\hline Obs. & 376 & 339 & 376 & 309 & 298 & 296 \\
\hline \hline
\end{tabular}

Note: This table shows $e^{s}$ and $\beta_{1}^{s}$ coefficients from regressions of the form $y_{s, i, t}=e^{s} \log \left(1-M T R_{i, t}^{s}\right)+$ $\beta_{1}^{s}$ Other $s_{i, t}+\beta_{2}^{s} Z_{i, t}+\gamma_{t}^{s}+\mu_{i}^{s}+\mu_{i}^{s} t^{s}+u_{i, t}^{s}$. Newey-West standard errors with 8 lags in parenthesis. Data on the number of tax brackets on personal income set by the central government are collected for 17 countries over the 1981-2010 period (data is not available for Germany over the whole time period, whereas tax schedules for Finland and Japan are available only since 2000) from OECD Tax Database. The controls are the same used in SCM estimations. $M T R^{s}$ are authors computations from OECD national tax schedules. Tax base data are authors computations combining tax features from OECD Tax Database and average reported income from WID. Data on top income shares are from WID. $* * * \mathrm{p}<0.01$, ** $\mathrm{p}<0.05, * \mathrm{p}<0.1$. 


\section{Appendix}

\section{Appendix A: Data appendix}

\section{A1. Summary statistics}

Table A1: Summary statistics

\begin{tabular}{|c|c|c|c|c|c|}
\hline Variable & Obs & Mean & Std. Dev. & Min & Max \\
\hline Top 10 & 713 & 31.635 & 4.608 & 18.77 & 46.35 \\
\hline Top 5 & 728 & 20.657 & 3.759 & 12.1 & 33.84 \\
\hline Top 1 & 763 & 8.005 & 2.422 & 3.49 & 18.33 \\
\hline Top 0.5 & 708 & 5.475 & 2.002 & 2.38 & 14.31 \\
\hline Top 0.1 & 598 & 2.399 & 1.292 & 0.73 & 8.25 \\
\hline Top 0.01 & 405 & 0.819 & 0.588 & 0.17 & 3.53 \\
\hline Top 10-5 & 677 & 10.907 & 1.25 & 6.28 & 14.77 \\
\hline Top 10-1 & 713 & 23.579 & 2.799 & 14.45 & 32.02 \\
\hline Top 1-0.1 & 713 & 6.121 & 1.57 & 3.21 & 13.44 \\
\hline Top 1-0.5 & 708 & 2.586 & 0.481 & 1.5 & 4.05 \\
\hline Top 0.5-0.1 & 582 & 3.206 & 0.851 & 1.63 & 6.15 \\
\hline$M T R^{t o p}$ & 918 & 0.557 & 0.136 & 0.28 & 0.963 \\
\hline$M T R^{10}$ & 386 & 0.469 & 0.107 & 0.269 & 0.755 \\
\hline$M T R^{1}$ & 386 & 0.487 & 0.1 & 0.269 & 0.755 \\
\hline$M T R^{0.5}$ & 385 & 0.491 & 0.1 & 0.269 & 0.755 \\
\hline$M T R^{0.1}$ & 340 & 0.504 & 0.1 & 0.269 & 0.755 \\
\hline$M T R^{10-5}$ & 357 & 0.456 & 0.114 & 0.26 & 0.735 \\
\hline$M T R^{10-1}$ & 350 & 0.451 & 0.1 & 0.26 & 0.755 \\
\hline$M T R^{1-0.1}$ & 320 & 0.474 & 0.095 & 0.269 & 0.755 \\
\hline$M T R^{1-0.5}$ & 384 & 0.483 & 0.098 & 0.269 & 0.755 \\
\hline$A T R^{10}$ & 386 & 0.379 & 0.095 & 0.225 & 0.637 \\
\hline$A T R^{1}$ & 386 & 0.441 & 0.09 & 0.278 & 0.707 \\
\hline$A T R^{0.5}$ & 385 & 0.454 & 0.091 & 0.281 & 0.72 \\
\hline$A T R^{0.1}$ & 340 & 0.484 & 0.094 & 0.286 & 0.749 \\
\hline$A T R^{10-5}$ & 357 & 0.348 & 0.116 & 0.189 & 0.65 \\
\hline$A T R^{1-0.5}$ & 384 & 0.421 & 0.098 & 0.269 & 0.681 \\
\hline Reform & 918 & 0.303 & 0.46 & 0 & 1 \\
\hline Significant Reform & 918 & 0.071 & 0.257 & 0 & 1 \\
\hline
\end{tabular}


Continues from previous page

\begin{tabular}{l|ccccc}
\hline ARP & 443 & 0.08 & 0.022 & 0.018 & 0.144 \\
MRP & 443 & 0.088 & 0.022 & 0.028 & 0.159 \\
GDP per-capita & 918 & 15349 & 5643 & 2956 & 31655 \\
GDP per-capita growth rate & 899 & 0.024 & 0.027 & -0.086 & 0.119 \\
Party Orientation & 600 & 0.481 & 0.469 & 0 & 1 \\
International Trade & 812 & 45.71 & 26.55 & 6.6 & 187.36 \\
Globalization & 918 & 69.332 & 13.495 & 34.05 & 92.509 \\
Debt & 918 & 42.302 & 27.68 & 3.3 & 189.1 \\
Debt Growth Rate & 900 & 0.018 & 0.14 & -0.33 & 1.08 \\
Central Government Spending & 830 & 0.177 & 0.046 & 0.072 & 0.301 \\
Gross Savings & 696 & 24.138 & 4.983 & 10.295 & 41.745 \\
Gross Fixed Capital & 831 & 24.115 & 3.773 & 15.914 & 37.228 \\
Bank Deposits & 830 & 0.574 & 0.229 & 0.154 & 1.416 \\
UK Legal Origin & 918 & 0.333 & 0.472 & 0 & 1 \\
Population Growth Rate & 918 & 0.756 & 1.037 & -0.9 & 26.4 \\
Working Age Population & 918 & 65.22 & 3 & 38.13 & 70.12 \\
Annual Hours Worked & 918 & 1816 & 217 & 1381 & 2621 \\
Trade Union Density & 918 & 39.184 & 19.533 & 7.548 & 83.863 \\
Stock Market & 831 & 0.475 & 0.434 & 0.002 & 3.034 \\
Financial Development & 918 & 1.11 & 0.581 & .33 & 4.349 \\
Patents & 824 & 22973 & 60171 & 54 & 384201 \\
Patents Growth & 806 & 0.018 & 0.112 & -0.505 & 0.815 \\
High Education & 162 & 11.179 & 6.589 & 0.83 & 30.94 \\
Enrollment Ratio & 657 & 42.74 & 21.072 & 7.273 & 97.093 \\
Human Capital & 918 & 2.74 & 0.455 & 1.538 & 3.619 \\
Tax Revenue & 828 & 0.327 & 0.076 & 0.133 & 0.495 \\
Tax Brackets & 470 & 6.202 & 4.919 & 1 & 34 \\
Tax Base & 379 & 0.873 & 0.106 & 0.576 & 0.999 \\
\hline \hline
\end{tabular}




\section{A2. Top income data}

Table A2: Characteristics of international top income data

\begin{tabular}{|c|c|c|}
\hline Country & Country specific information & Change to original data \\
\hline Australia & $\begin{array}{l}\text { Income year goes from July } 1 \text { st year } \mathrm{t} \text { to June } 30 \text { year } \mathrm{t}+1 \text {. } \\
\text { Capital gains are included. }\end{array}$ & No. \\
\hline Canada & $\begin{array}{l}\text { Estimates excluding capital gains. Fractiles defined by } \\
\text { total gross income excluding capital gains. Until } 1981 \text { the } \\
\text { series of every top group are based on tabulated tax data, } \\
\text { and relate to adults age } 20+\text {. Since } 1982 \text {, the series are } \\
\text { based on LAD (Longitudinal Administrative Database) } \\
\text { and relate to taxfilers. }\end{array}$ & No. \\
\hline Denmark & $\begin{array}{l}\text { Estimates excluding capital gains. Fractiles defined by } \\
\text { total gross income excluding capital gains. Until } 1968 \text { tax } \\
\text { units were individuals aged } 15+\text { minus married females. } \\
1969 \text { was a tax free year. Since } 1970 \text {, the tax units have } \\
\text { become individuals aged } 15+\text { (some individuals below } 15 \\
\text { years also file a tax return if they earn a sufficiently high } \\
\text { income). }\end{array}$ & $\begin{array}{l}\text { Linear interpolation for year } 1969 \\
\text { for each category. Linear interpo- } \\
\text { lation for year } 1973 \text { for Top } 1 \text { and } \\
\text { categories below. Interpolated for } \\
\text { years } 1967-1970 \text { and } 1974-1976 \\
\text { for Top } 0.1 \text { and categories below. }\end{array}$ \\
\hline Finland & $\begin{array}{l}\text { Until } 1992 \text { the series are based on tabulated tax data by } \\
\text { ranges of income where the unit of analysis is the tax } \\
\text { unit, and the income concept is taxable income. Since } \\
1990 \text {, the series are based on IDS (Income Distribution } \\
\text { Survey), where the unit of analysis is the individual aged } \\
\text { 15+ with non-zero incomes, and the income concept is } \\
\text { taxable income. }\end{array}$ & No. \\
\hline France & $\begin{array}{l}\text { Series expressed as percentage of total income excluding } \\
\text { capital gains. Fractiles defined by total income excluding } \\
\text { capital gains. }\end{array}$ & No. \\
\hline Germany & $\begin{array}{l}\text { Estimates excluding capital gains. West Germany prior } \\
\text { to } 1990 \text {, with families as tax units. Data available every } \\
\text { third year. }\end{array}$ & $\begin{array}{l}\text { Linear interpolation from trian- } \\
\text { nual data since } 1961 \text {. }\end{array}$ \\
\hline Ireland & $\begin{array}{l}\text { Estimates excluding capital gains. Up to } 1973 \text {, estimates } \\
\text { based on surtax return. Since 1975, estimates based on } \\
\text { income tax returns. }\end{array}$ & $\begin{array}{l}\text { Constant level of Top } 10,1 \text {, and } \\
1-0.5 \text { for } 1960-1974 \text {. For Top } \\
0.5 \text { constant level for } 1960-1964 \text {, } \\
\text { linear interpolation for } 1967-1972 \\
\text { and } 1974 \text {. }\end{array}$ \\
\hline Italy & $\begin{array}{l}\text { Estimates do not include most capital gains and several } \\
\text { components of capital incomes (as interest income). }\end{array}$ & $\begin{array}{l}\text { Constant level for 1960-1973, lin- } \\
\text { ear interpolation in } 1996 \text { and } \\
1997 .\end{array}$ \\
\hline Japan & $\begin{array}{l}\text { Estimates excluding capital gains. Fractiles defined by } \\
\text { total income excluding capital gains. Tax unit is individ- } \\
\text { ual. }\end{array}$ & No. \\
\hline Netherlands & $\begin{array}{l}\text { Estimates excluding capital gains. Until } 1975 \text { estimates } \\
\text { based on tabulated data produced by the Central Bureau } \\
\text { of Statistics. Since } 1977 \text {, estimated based on micro-data } \\
\text { Income Panel Survey (IPO) using tax and other adminis- } \\
\text { trative data. There is a break in the series in } 2000 / 2001 \text {, } \\
\text { due to changes of definitions and observations that were } \\
\text { made to Dutch income statistics by Statistics Nether- } \\
\text { lands. Data every second or fourth year from } 1960 \text { to } \\
\text { 1989. Tax unit is family. }\end{array}$ & $\begin{array}{l}\text { Linear interpolation from } 1961 \text { to } \\
1989 .\end{array}$ \\
\hline New Zealand & $\begin{array}{l}\text { Tax unit is individual. Estimates including capital gains } \\
\text { when taxable. }\end{array}$ & No. \\
\hline
\end{tabular}


Continues from previous page

\begin{tabular}{|c|c|c|}
\hline Norway & Tax unit is individual. Estimates including capital gains. & No. \\
\hline Portugal & Estimates excluding most capital gains. & $\begin{array}{l}\text { Constant level for } 2006-2010 \text {. For } \\
\text { Top } 10,1,0.5,10-5 \text {, and } 5-1 \text {, } \\
0.5-0.1 \text { constant level for } 1960- \\
1975 \text { and interpolations for } 1983- \\
1988 \text {. For Top } 0.1 \text { interpolations } \\
\text { for } 1979-1988 \text {. }\end{array}$ \\
\hline Spain & Estimates excluding capital gains. Tax unit is individual. & Constant level for 1960-1980. \\
\hline Sweden & Estimates excluding capital gains. Tax unit is individual. & No. \\
\hline Switzerland & Estimates excluding capital gains. Tax unit is family. & $\begin{array}{l}\text { Linear interpolation from bian- } \\
\text { nual data. }\end{array}$ \\
\hline United Kingdom & $\begin{array}{l}\text { Capital gains included when taxable. Until 1974, esti- } \\
\text { mates relate to income net of certain deductions; from } \\
1975 \text {, estimates relate to total income. Until } 1989 \text { origi- } \\
\text { nal estimates relate to tax units (married couples and sin- } \\
\text { gle adults), while, from 1990, original estimates relate to } \\
\text { adults. }\end{array}$ & $\begin{array}{l}\text { Linear interpolations for } 1961 \text {, } \\
1980 \text { and } 2008 \text {. For Top } 0.1 \\
\text { and } 0.5-0.1 \text { interpolation for } 1987- \\
1992 .\end{array}$ \\
\hline United States & Estimates excluding capital gains. Tax unit is family. & No. \\
\hline
\end{tabular}

Note: see the original source for further details (World Wealth and Income Database, accessed on 04/02/2016: http://www.wid.world/). We use linear interpolations since the synthetic control method relies on a full matrix of pretreatment observations and missing observations can disturb the computations. When we do not use the synthetic control method, the original data is used.

Table A3: Groups of income share for which country-data are available (1960-2010)

\begin{tabular}{|c|c|c|c|c|c|c|c|c|}
\hline Country & Top 10 & Top 1 & Top 0.5 & Top 0.1 & Top 10-5 & Top 5-1 & Top 1-0.5 & Top 0.5-0.1 \\
\hline Australia & $\mathrm{x}$ & $\mathrm{x}$ & $\mathrm{x}$ & $\mathrm{x}$ & & $\mathrm{x}$ & $\mathrm{x}$ & $\mathrm{x}$ \\
\hline Canada & $\mathrm{x}$ & $\mathrm{x}$ & $\mathrm{x}$ & $\mathrm{x}$ & $\mathrm{x}$ & $\mathrm{x}$ & $\mathrm{x}$ & $\mathrm{x}$ \\
\hline Denmark & $\mathrm{x}$ & $\mathrm{x}$ & $\mathrm{x}$ & $\mathrm{x}$ & $\mathrm{x}$ & $\mathrm{x}$ & $\mathrm{x}$ & $\mathrm{x}$ \\
\hline Finland & & $\mathrm{x}$ & & & & & & \\
\hline France & $\mathrm{x}$ & $\mathrm{x}$ & $\mathrm{X}$ & $\mathrm{X}$ & $\mathrm{X}$ & $\mathrm{X}$ & $\mathrm{X}$ & $\mathrm{X}$ \\
\hline Germany & $\mathrm{x}$ & $\mathrm{x}$ & $\mathrm{x}$ & $\mathrm{X}$ & $\mathrm{x}$ & $\mathrm{x}$ & $\mathrm{x}$ & $\mathrm{x}$ \\
\hline Ireland & $\mathrm{x}$ & $\mathrm{x}$ & $\mathrm{X}$ & & & & $\mathrm{x}$ & \\
\hline Italy & $\mathrm{x}$ & $\mathrm{x}$ & $\mathrm{x}$ & $\mathrm{x}$ & $\mathrm{x}$ & $\mathrm{x}$ & $\mathrm{x}$ & $\mathrm{X}$ \\
\hline Japan & $\mathrm{x}$ & $\mathrm{x}$ & $\mathrm{x}$ & $\mathrm{x}$ & $\mathrm{x}$ & $\mathrm{x}$ & $\mathrm{x}$ & $\mathrm{x}$ \\
\hline Netherlands & $\mathrm{x}$ & $\mathrm{x}$ & $\mathrm{x}$ & & $\mathrm{x}$ & $\mathrm{x}$ & $\mathrm{x}$ & \\
\hline New Zealand & $\mathrm{x}$ & $\mathrm{x}$ & $\mathrm{x}$ & & $\mathrm{x}$ & $\mathrm{x}$ & $\mathrm{x}$ & \\
\hline Norway & $\mathrm{x}$ & $\mathrm{x}$ & $\mathrm{x}$ & $\mathrm{x}$ & $\mathrm{x}$ & $\mathrm{x}$ & $\mathrm{x}$ & $\mathrm{X}$ \\
\hline Portugal & $\mathrm{x}$ & $\mathrm{x}$ & $\mathrm{x}$ & $\mathrm{x}$ & $\mathrm{x}$ & $\mathrm{x}$ & $\mathrm{x}$ & $\mathrm{x}$ \\
\hline Spain & $\mathrm{x}$ & $\mathrm{x}$ & $\mathrm{x}$ & $\mathrm{x}$ & $\mathrm{x}$ & $\mathrm{x}$ & $\mathrm{x}$ & $\mathrm{x}$ \\
\hline Sweden & $\mathrm{X}$ & $\mathrm{X}$ & $\mathrm{X}$ & $\mathrm{X}$ & $\mathrm{X}$ & $\mathrm{x}$ & $\mathrm{x}$ & $\mathrm{X}$ \\
\hline Switzerland & $\mathrm{x}$ & $\mathrm{x}$ & $\mathrm{x}$ & $\mathrm{X}$ & $\mathrm{x}$ & $\mathrm{x}$ & $\mathrm{x}$ & $\mathrm{X}$ \\
\hline United Kingdom & $\mathrm{x}$ & $\mathrm{x}$ & $\mathrm{x}$ & $\mathrm{X}$ & $\mathrm{x}$ & $\mathrm{x}$ & $\mathrm{x}$ & $\mathrm{X}$ \\
\hline United States & $\mathrm{x}$ & $\mathrm{x}$ & $\mathrm{x}$ & $\mathrm{X}$ & $\mathrm{x}$ & $\mathrm{x}$ & $\mathrm{x}$ & $\mathrm{X}$ \\
\hline
\end{tabular}




\section{A3. Control variables description}

Table A4: Description of control variables

\begin{tabular}{|c|c|c|}
\hline Control variable & Description & Source \\
\hline$M T R^{t o p}$ & $\begin{array}{l}\text { Top statutory PIT rate. Legally determined marginal tax } \\
\text { rate applicable to the top bracket of the personal income } \\
\text { tax schedule. }\end{array}$ & Piketty et al. (2014). \\
\hline GDP per-capita & $\begin{array}{l}\text { Value of all final goods and services produced within a } \\
\text { country in a given year, divided by the average population } \\
\text { for the same year. }\end{array}$ & $\begin{array}{l}\text { The Maddison-Project, } 2013 \text { ver- } \\
\text { sion. }\end{array}$ \\
\hline ARP and MRP & $\begin{array}{l}\text { Average (marginal) rate progression up to an income } \\
\text { level equivalent to four times the GDP per-capita. The } \\
\text { ATR/MTR used adjusts for allowances/deductions, tax } \\
\text { credits, significant local taxes and other main rules of tax } \\
\text { code. It does not adjust for deductions, exemptions, and } \\
\text { credits that depend on taxpayer specific characteristics } \\
\text { (for example, no adjustment is made for child credits). } \\
\text { The rate does not account for evasion/avoidance. }\end{array}$ & $\begin{array}{l}\text { Andrew Young School of Policy } \\
\text { Studies (2010) }\end{array}$ \\
\hline Party Orientation & $\begin{array}{l}\text { It is the party orientation with respect to economic pol- } \\
\text { icy, coded based on the description of the party in the } \\
\text { sources. It classifies into four different categories: right } \\
(=0) \text {, center }(=0.5) \text {, left }(=1) \text {, and no information or no } \\
\text { executive (=missing value). The classification is made } \\
\text { using the following criteria. Right: for parties that are } \\
\text { defined as conservative, Christian democratic, or right- } \\
\text { wing; left: for parties that are defined as communist, so- } \\
\text { cialist, social democratic, or left-wing; center: for parties } \\
\text { that are defined as centrist or when party position can best } \\
\text { described as centrist (e.g. party advocates strenghtening } \\
\text { private enterprise in a social-liberal context); no informa- } \\
\text { tion or no executive for all those cases which do not fit } \\
\text { into the above-mentioned category or no information. }\end{array}$ & Keefer (2012) \\
\hline International Trade & $\begin{array}{l}\text { It is the sum of exports and imports of goods and services } \\
\text { measured as a share of GDP. }\end{array}$ & Roine et al. (2009) \\
\hline Globalization & $\begin{array}{l}2016 \text { KOF Index of Globalization. It takes into account } \\
\text { of economic (e.g. trade, FDI, tariff rate) social (e.g. tele- } \\
\text { phone traffic, internet users, number of Ikea) and politi- } \\
\text { cal (e.g. embassies in country, international treaties) vari- } \\
\text { ables for defining globalization. See the source for further } \\
\text { details. }\end{array}$ & $\begin{array}{l}\text { Dreher (2006) with updated esti- } \\
\text { mations. }\end{array}$ \\
\hline Debt Growth Rate & $\begin{array}{l}\text { Growth rate of total (domestic plus external) gross central } \\
\text { government debt as a share of GDP }\end{array}$ & Reinhart and Rogoff (2010) \\
\hline $\begin{array}{l}\text { Central Government } \\
\text { Spending }\end{array}$ & Central government spending as a share of GDP. & Roine et al. (2009) \\
\hline Gross Savings & $\begin{array}{l}\text { Gross savings are calculated as gross national income less } \\
\text { total consumption, plus net transfers. They are computed } \\
\text { as share of GDP. }\end{array}$ & World Bank. \\
\hline Gross Fixed Capital & $\begin{array}{l}\text { Gross fixed capital formation (formerly gross domestic } \\
\text { fixed investment) includes land improvements (fences, } \\
\text { ditches, drains, and so on); plant, machinery, and equip- } \\
\text { ment. It is computed as share of GDP. }\end{array}$ & World Bank. \\
\hline
\end{tabular}

Continues on next page 
continues from previous page

\begin{tabular}{|c|c|c|}
\hline Bank Deposits & Bank deposits as a share of GDP & Roine et al. (2009) \\
\hline Stock Market & Stock market capitalization as a share of GDP. & Roine et al. (2009) \\
\hline $\begin{array}{l}\text { Financial Develop- } \\
\text { ment }\end{array}$ & $\begin{array}{l}\text { Equal to the sum of the variables Bank Deposits and } \\
\text { Stock Market }\end{array}$ & Roine et al. (2009) \\
\hline UK Legal Origin & $\begin{array}{l}\text { Dummy variable equals to } 1 \text { whether the country official } \\
\text { language is English; } 0 \text { otherwise. }\end{array}$ & Laporta et al. (1997) \\
\hline $\begin{array}{l}\text { Population Growth } \\
\text { Rate }\end{array}$ & Percentage growth of population & OECD \\
\hline $\begin{array}{l}\text { Working Age Popula- } \\
\text { tion }\end{array}$ & $\begin{array}{l}\text { The working age population is defined as those aged } 15 \\
\text { to } 64 \text {. The basic indicator for employment is the propor- } \\
\text { tion of the working age population aged } 15-64 \text { who are } \\
\text { employed. The age dependency ratio is the ratio of de- } \\
\text { pendents (people younger than } 15 \text { or older than } 64 \text { ) to the } \\
\text { working-age population. This indicator is measured as a } \\
\text { percentage of population. }\end{array}$ & OECD \\
\hline Annual Hours Worked & Average annual hours worked by persons engaged. & Penn World Table (2015) \\
\hline Trade Union Density & Trade union density as a share of employees. & OECD \\
\hline Patents Growth & Annual growth rate of number of patents recorded. & Roine et al. (2009) \\
\hline High-Education & $\begin{array}{l}\text { Percentage of population age } 25+\text { that have completed } \\
\text { tertiary schooling. Data since } 1970 \text { collected each } 5 \text { years }\end{array}$ & Barro and Lee (2012) \\
\hline Enrollment Ratio & $\begin{array}{l}\text { School enrollment in tertiary education (percent gross). } \\
\text { Gross enrollment ratio is the ratio of total enrollment, re- } \\
\text { gardless of age, to the population of the age group that of- } \\
\text { ficially corresponds to the level of tertiary education. Ter- } \\
\text { tiary education, whether or not to an advanced research } \\
\text { qualification, normally requires, as a minimum condition } \\
\text { of admission, the successful completion of education at } \\
\text { the secondary level. }\end{array}$ & UNESCO \\
\hline Human Capital & $\begin{array}{l}\text { Index of human capital per person, based on years of } \\
\text { schooling (Barro/Lee, 2012) and returns to education } \\
\text { (Psacharopoulos, 1994) }\end{array}$ & $\begin{array}{l}\text { Barro and Lee (2012) and } \\
\text { Psacharopoulos (1994) }\end{array}$ \\
\hline Tax Revenue & $\begin{array}{l}\text { Tax revenue as a share of GDP. Tax revenue is defined as } \\
\text { the revenues collected from taxes on income and profits, } \\
\text { social security contributions, taxes levied on goods and } \\
\text { services, payroll taxes, taxes on the ownership and trans- } \\
\text { fer of property, and other taxes. Total tax revenue as a } \\
\text { percentage of GDP indicates the share of a country's out- } \\
\text { put that is collected by the government through taxes. It } \\
\text { can be regarded as one measure of the degree to which } \\
\text { the government controls the economy's resources. The } \\
\text { tax burden is measured by taking the total tax revenues } \\
\text { received as a percentage of GDP. This indicator relates } \\
\text { to government as a whole (all government levels) and is } \\
\text { measured in USD. }\end{array}$ & OECD \\
\hline
\end{tabular}

\section{A4. Omega values for reforms}

Omega values relies on the procedure used to estimate the ARP, which is computed as:

$$
A R P_{i, t}=\frac{A T R_{i, t}^{t o p}-A T R_{i, t}^{a v g}}{\left(Y_{i, t}^{t o p} / Y_{i, t}^{a v g}\right)-1} .
$$

It should be noted that changes in ARP can occur for two reasons: tax rate changes or income variations. Changes in the tax rate faced by the top and the average earner will produce a 
variation in the numerator of the ARP formula. All else equal, if both tax liabilities increase (decrease) by the same percentage, it turns out that the difference between $A T R^{\text {top }}$ and $A T R^{a v g}$ increases (decreases) and, thus, ARP will increase (decrease). On the other hand, changes in income affect directly the denominator and indirectly the tax liability. Assuming constant tax rates, ARP will decrease (increase) if incomes of both top earner $\left(Y^{t o p}\right)$ and average earner $\left(Y^{a v g}\right)$ increase (decrease) by the same percentage.

Since we wish to identify changes in progressivity stimulated by variations in tax schedules, it becomes important to distinguish whether the variation in ARP is due to tax rate or income changes. To account for this issue, we select only the reform in which we find a significant variation in tax rates, and remove the changes in $\Omega$ only due to income variations. In the table below, we provide information on the changes in the ATR and in the number of tax brackets.

Table A5: Omega values

\begin{tabular}{l|c|c|c|c|c|c} 
Country & Reform Years & $\mathrm{t}=1$ & $\Delta A T R^{\text {top }}$ & $\Delta A T R^{\text {avg }}$ & $\Delta$ Brackets & $\Omega$ \\
\hline \hline Australia & $1985-1987$ & 1987 & $55.45 \rightarrow 47.03$ & $33.26 \rightarrow 29.24$ & $7 \rightarrow 5$ & -0.02628 \\
Canada (I) & 1982 & 1982 & $56.91 \rightarrow 51.50$ & $42.16 \rightarrow 39.36$ & $13 \rightarrow 10$ & -0.00578 \\
Canada (II) & $1987-1988$ & 1988 & $54.02 \rightarrow 44.09$ & $40.87 \rightarrow 29.70$ & $10 \rightarrow 3$ & -0.00085 \\
Finland* & 1991 & 1991 & $37.73 \rightarrow 31.94$ & $15.76 \rightarrow 10.08$ & n.a. & -0.00036 \\
France (I) & $1986-1987$ & 1986 & $59.91 \rightarrow 53.15$ & $32.73 \rightarrow 30.53$ & $15 \rightarrow 13$ & -0.01035 \\
France (II) & 1996 & 1996 & $51.80 \rightarrow 49.15$ & $25.36 \rightarrow 23.36$ & $7 \rightarrow 7$ & -0.00116 \\
Germany* & $2003-2005$ & 2005 & $40.07 \rightarrow 31.78$ & $21.07 \rightarrow 13.82$ & n.a. & -0.00349 \\
Ireland (I) & $1985-1986$ & 1985 & $59.09 \rightarrow 52.61$ & $36.04 \rightarrow 32.33$ & $5 \rightarrow 3$ & -0.00253 \\
Ireland (II) & 1992 & 1992 & $49.33 \rightarrow 45.48$ & $29.65 \rightarrow 28.26$ & $3 \rightarrow 2$ & -0.00603 \\
Italy (I) & 1986 & 1986 & $37.85 \rightarrow 34.47$ & $17.52 \rightarrow 14.84$ & $9 \rightarrow 9$ & -0.00297 \\
Italy (II) & 1989 & 1989 & $35.88 \rightarrow 33.42$ & $14.84 \rightarrow 13.95$ & $9 \rightarrow 7$ & -0.00322 \\
Netherlands & 1990 & 1990 & $61.61 \rightarrow 52.79$ & $31.59 \rightarrow 23.63$ & $9 \rightarrow 3$ & -0.00001 \\
New Zealand & $1986-1989$ & 1989 & $59.84 \rightarrow 31.78$ & $33.38 \rightarrow 24.99$ & $5 \rightarrow 3$ & -0.04650 \\
Norway & $1990-1992$ & 1992 & $49.17 \rightarrow 40.06$ & $33.77 \rightarrow 31.58$ & $3 \rightarrow 1$ & -0.02989 \\
Spain (I) & $2003-2004$ & 2003 & $41.82 \rightarrow 39.89$ & $23.38 \rightarrow 21.07$ & $6 \rightarrow 5$ & -0.00001 \\
Spain (II) & 2007 & 2007 & $40.19 \rightarrow 38.25$ & $21.45 \rightarrow 20.27$ & $5 \rightarrow 4$ & -0.00144 \\
Sweden* & 1991 & 1991 & $44.30 \rightarrow 36.20$ & $15.80 \rightarrow 10.60$ & $4 \rightarrow 2$ & -0.00967 \\
UK & 1988 & 1988 & $54.59 \rightarrow 38.18$ & $26.29 \rightarrow 24.32$ & $6 \rightarrow 2$ & -0.02358 \\
US (I) & 1982 & 1982 & $70.71 \rightarrow 53.95$ & $45.88 \rightarrow 42.44$ & $17 \rightarrow 14$ & -0.01976 \\
US (II) & $1987-1988$ & 1987 & $52.74 \rightarrow 32.82$ & $31.14 \rightarrow 27.11$ & $16 \rightarrow 2$ & -0.02188 \\
US (III) & 2003 & 2003 & $42.23 \rightarrow 39.11$ & $25.11 \rightarrow 23.76$ & $6 \rightarrow 6$ & -0.00143 \\
\hline \hline
\end{tabular}

Note: $\triangle A T R^{\text {top }}$ and $\triangle A T R^{a v g}$ display respectively the pre-reform and post-reform $A T R$ faced by an earner whose income is equal to the average reported income by the top percentile and by an earners whose income is equal to the average reported income. $\Delta$ Brackets shows the pre-reform and post-reform number of tax brackets on wage income. For countries marked with * (Finland, Germany, and Sweden) the ARP is derived computing the ATR faced by an earner whose income is equal to 4 time GDP percapita and an earner whose income is equal to GDP per-capita. $t=1$ corresponds to the year since which the dummy reform equals one. In the case a country has implemented a single "significant" reform, the dummy reform corresponds with $\mathrm{t}=1$ in the table. Then, we have the following: AUS 1987, FIN 1991, GER 2005, NET 1990, NWZ 1989, NOR 1992, SWE 1991, and UK 1988. In the cases of multiple reforms, we select the most relevant in $\Omega$ terms: CAN 1982, FRA 1986, ITA 1989, IRE 1992, ESP 2007 , and US 1987. We do not find any important negative variation in $\Omega$ over the period covered in Denmark (1981-2010), Japan (2000-2010), Portugal (1989 - 2005), and Switzerland (1981-2010). 


\section{Appendix B: Synthetic Control Method estimations}

This Appendix provides the tables showing the weights assigned by the SCM to construct the synthetic control and the pre-treatment trends for the control variable used in the baseline model. The baseline model uses the following control variables: GDP per-capita, globalization, annual hours worked, human capital, financial development, trade union density, $M T R^{t o p}$, ARP, and debt growth rate. The choice is made so that several potential determinants of top income shares are considered in the pre-treatment period. The last three variables are selected to capture the potential endogeneity of the tax reform. Tables contain also the root mean square prediction error (RMSPE), which evaluates how the synthetic control succeed to be similar to the treated. The RMSPE computes the lack of fit between the path of top income shares in the treated country and in the synthetic counterpart. It is defined as:

$$
R M S P E=\left[\frac{1}{T_{O}} \sum_{t=1}^{T_{O}}\left(Y_{1, t}-\sum_{j=2}^{J} w_{j}^{*} Y_{j, t}\right)^{2}\right]^{\frac{1}{2}}
$$


Table B1: Australia: synthetic control composition

a) Synthetic control groups composition

\begin{tabular}{|c|c|c|c|c|c|c|}
\hline \multirow[t]{2}{*}{ Country } & \multicolumn{6}{|c|}{ Weights } \\
\hline & Top 10 & Top 1 & Top 0.1 & Top 5-1 & Top 1-0.5 & Top 0.5-0.1 \\
\hline Canada & & & & & & \\
\hline Denmark & & & & & & \\
\hline Finland & - & & - & - & - & - \\
\hline France & & & & & & \\
\hline Germany & & & & 0.379 & & \\
\hline Ireland & 0.289 & 0.144 & - & - & 0.143 & - \\
\hline Italy & & & & & & \\
\hline Japan & & & & & & 0.126 \\
\hline Netherlands & & 0.093 & - & 0.128 & 0.097 & - \\
\hline Portugal & & & & & & \\
\hline Spain & & & 0.162 & & & \\
\hline Sweden & 0.711 & 0.763 & 0.838 & 0.493 & 0.76 & 0.874 \\
\hline Switzerland & & & & & & \\
\hline
\end{tabular}

b) Control variables

\begin{tabular}{l|c|cccccc}
\hline Variable & AUS & \multicolumn{6}{|c}{ Synthetic AUS } \\
\hline & & Top 10 & Top 1 & Top 0.1 & Top 5-1 & Top 1-0.5 & Top 0.5-0.1 \\
\hline \hline GDP Per-Capita & 12007 & 10866 & 11669 & 11635 & 11977 & 11672 & 12197 \\
Globalization & 64.85 & 69.8 & 70.26 & 67.08 & 64.43 & 70.28 & 66.52 \\
Financial Development & 0.95 & 0.68 & 0.68 & 0.67 & 0.68 & 0.68 & 0.68 \\
Annual Hours Worked & 1843 & 1886 & 1922 & 1848 & 1966 & 1924 & 1877 \\
Trade Union Density & 47.79 & 65.83 & 65.78 & 62.74 & 53.15 & 65.67 & 67.42 \\
Human Capital & 3.02 & 3 & 3.04 & 3.12 & 2.64 & 3.04 & 3.1 \\
Top MTR & 0.65 & 0.75 & 0.75 & 0.71 & 0.67 & 0.75 & 0.76 \\
Debt Growth Rate & -0.04 & 0.03 & 0.03 & 0.03 & 0.03 & 0.03 & 0.04 \\
ARP & 0.10 & 0.14 & 0.14 & 0.13 & 0.12 & 0.14 & 0.13 \\
RMSPE & & 0.89 & 0.23 & 0.07 & 0.35 & 0.1 & 0.11 \\
\hline Top income share AUS & & 27.34 & 5.84 & 1.27 & 11.24 & 2.16 & 2.42 \\
Top income share Synthetic AUS & & 27.84 & 5.89 & 1.28 & 11.35 & 2.18 & 2.43 \\
\hline \hline
\end{tabular}

Note: Panel a) shows the weight assigned to each country in the donor pool to compose the synthetic control. The synthetic control is chosen to best fit each different top income trend and control variables before the reform.

Panel b) shows the value of the control variables used in the baseline model to find the optimal synthetic control group in the pre-reform period. The control variables are described in Table A4. 
Table B2: New Zealand: synthetic control composition

a) Synthetic control groups composition

\begin{tabular}{l|cccccc}
\hline Country & \multicolumn{7}{c}{ Weights } \\
\hline \hline Canada & Top 10 & Top 1 & Top 0.5 & Top 10-5 & Top 5-1 & Top 1-0.5 \\
Denmark & 0.048 & & & 0.179 & 0.097 & \\
Finland & 0.52 & 0.108 & & 0.108 & 0.369 & 0.154 \\
France & - & & - & - & - & - \\
Germany & 0.124 & & & & 0.263 & \\
Ireland & & & & & 0.213 & 0.265 \\
Italy & 0.286 & 0.344 & & - & - & 0.185 \\
Japan & & 0.03 & 0.234 & 0.062 & & \\
Netherlands & & & & & & \\
Portugal & & & & 0.115 & & 0.019 \\
$\quad$ Spain & 0.022 & 0.389 & 0.182 & & 0.152 \\
Sweden & & & 0.169 & 0.335 & & \\
Switzerland & & 0.129 & 0.414 & 0.201 & 0.036 & 0.244 \\
\hline \hline
\end{tabular}

\begin{tabular}{l|c|cccccc}
\hline \hline \multicolumn{7}{c}{ b) Control variables } \\
\hline Variable & NWZ & \multicolumn{7}{c}{ Synthetic NWZ } \\
\hline & & Top 10 & Top 1 & Top 0.5 & Top 10-5 & Top 5-1 & Top 1-0.5 \\
\hline GDP Per-Capita & 11889 & 11337 & 8305 & 10260 & 11033 & 12760 & 10647 \\
Globalization & 59.98 & 69.88 & 63.17 & 60.86 & 65.56 & 66.02 & 64.22 \\
Financial Development & 0.56 & 0.58 & 0.7 & 0.73 & 0.84 & 0.62 & 0.66 \\
Annual Hours Worked & 2062 & 1893 & 1872 & 1842 & 1899 & 1877 & 1889 \\
Trade Union Density & 59.04 & 54.56 & 57.28 & 52.11 & 38.71 & 44.07 & 55.22 \\
Human Capital & 2.11 & 2.64 & 2.61 & 2.73 & 2.8 & 2.58 & 2.55 \\
Top MTR & 0.59 & 0.63 & 0.66 & 0.66 & 0.61 & 0.61 & 0.65 \\
Debt Growth Rate & 0.01 & 0.05 & 0.02 & 0.03 & 0.02 & 0.04 & 0.03 \\
ARP & 0.09 & 0.1 & 0.1 & 0.09 & 0.09 & 0.09 & 0.11 \\
RMSPE & & 0.7 & 0.41 & 0.32 & 0.27 & 0.3 & 0.13 \\
\hline Top income share NWZ & & 30.11 & 6.47 & 4.09 & 11.27 & 12.38 & 2.38 \\
Top income share Synthetic NWZ & & 30.11 & 6.47 & 4.11 & 11.25 & 12.36 & 2.39 \\
\hline \hline
\end{tabular}

Note: Panel a) shows the weight assigned to each country in the donor pool to compose the synthetic control. The synthetic control is chosen to best fit each different top income trend and control variables before the reform. Panel b) shows the value of the control variables used in the baseline model to find the optimal synthetic control group in the pre-reform period. The control variables are described in Table A4 . 
Table B3: Norway: synthetic control composition

a) Synthetic control groups composition

\begin{tabular}{|c|c|c|c|c|c|c|}
\hline \multirow[t]{2}{*}{ Country } & \multicolumn{6}{|c|}{ Weights } \\
\hline & Top 10 & Top 1 & Top 0.1 & Top 10-5 & Top 1-0.5 & Top 0.5-0.1 \\
\hline Canada & & & 0.258 & & & \\
\hline Denmark & 0.606 & & & 0.398 & 0.095 & \\
\hline Finland & - & & - & - & & - \\
\hline France & & & & & & \\
\hline Germany & & & & & & \\
\hline Ireland & & 0.148 & - & - & 0.093 & - \\
\hline Italy & & & & & & \\
\hline Japan & & & & & & \\
\hline Netherlands & & & - & & & - \\
\hline Portugal & & & & & & \\
\hline Spain & & & & & & 0.029 \\
\hline Sweden & 0.394 & 0.852 & 0.742 & 0.602 & 0.812 & 0.971 \\
\hline Switzerland & & & & & & \\
\hline
\end{tabular}

\begin{tabular}{l|c|cccccc}
\hline \hline \multicolumn{7}{|c}{ b) Control variables } \\
\hline Variable & NOR & \multicolumn{5}{c}{ Synthetic NOR } \\
\hline GDP Per-Capita & & Top 10 & Top 1 & Top 0.1 & Top 10-5 & Top 1-0.5 & Top 0.5-0.1 \\
Globalization & 12654 & 13792 & 13675 & 13285 & 13678 & 13012 & 13368 \\
Financial Development & 70.22 & 72.54 & 72.82 & 72.31 & 74.12 & 72.79 & 72.57 \\
Annual Hours Worked & 0.67 & 0.55 & 0.61 & 0.69 & 0.84 & 0.67 & 0.69 \\
Trade Union Density & 2141 & 1864 & 1863 & 1836 & 1856 & 1851 & 1837 \\
Human Capital & 56.88 & 70.59 & 71.43 & 71.7 & 63.45 & 71.47 & 72.56 \\
Top MTR & 2.71 & 2.95 & 3.06 & 3.21 & 3.13 & 3.11 & 3.22 \\
Debt Growth Rate & 0.69 & 0.66 & 0.7 & 0.75 & 0.73 & 0.74 & 0.76 \\
ARP & 0 & 0.05 & 0.03 & 0.02 & 0.02 & 0.02 & 0.02 \\
RMSPE & 0.1 & 0.11 & 0.12 & 0.12 & 0.11 & 0.12 & 0.12 \\
Top income share NOR & & 1.09 & 0.3 & 0.55 & 1.09 & 0.1 & 0.15 \\
Top income share Synthetic NOR & & 27.8 & 16.94 & 3.28 & 10.93 & 2.05 & 2.16 \\
\hline \hline
\end{tabular}

Note: Panel a) shows the weight assigned to each country in the donor pool to compose the synthetic control. The synthetic control is chosen to best fit each different top income trend and control variables before the reform.

Panel b) shows the value of the control variables used in the baseline model to find the optimal synthetic control group in the pre-reform period. The control variables are described in Table A4.

\section{Appendix C: Robustness analysis of main results}

\section{C1. "In-space" placebo test}


Figure C1: "In-space" placebo test
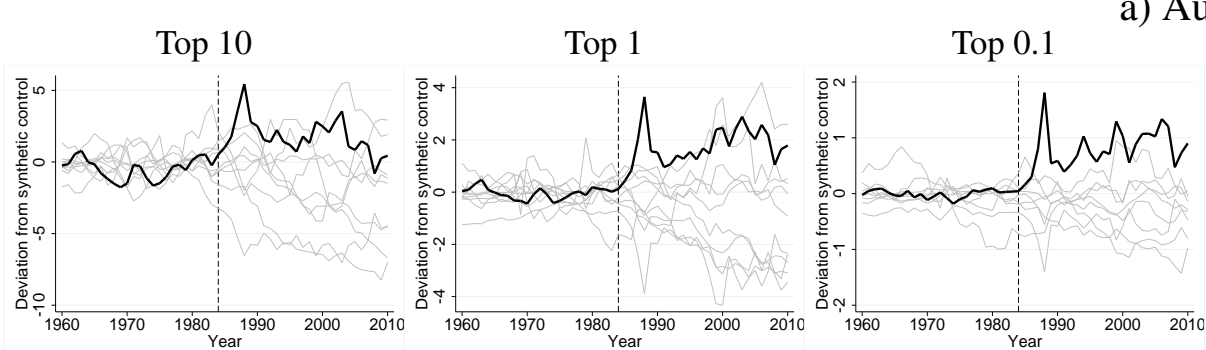

a) Australia

Top 10

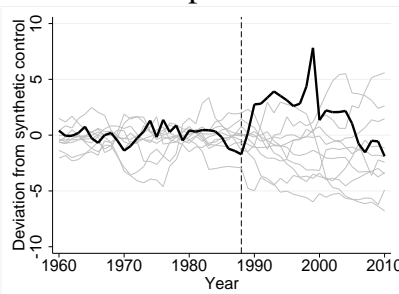

Top 10

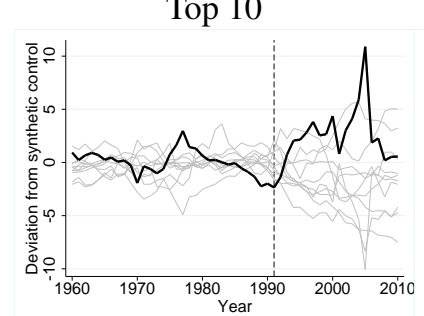

Top 1

Top 1
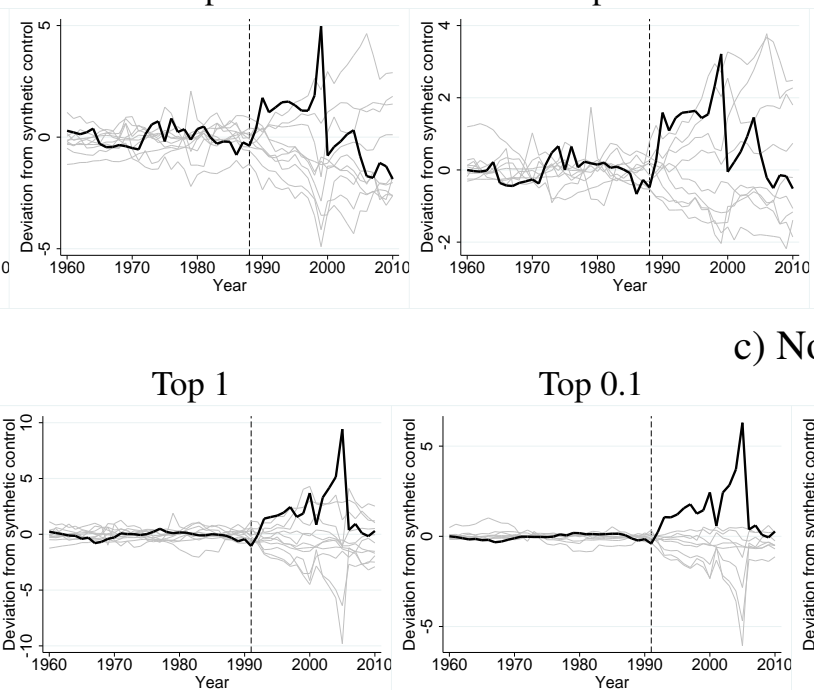

Top 0.1

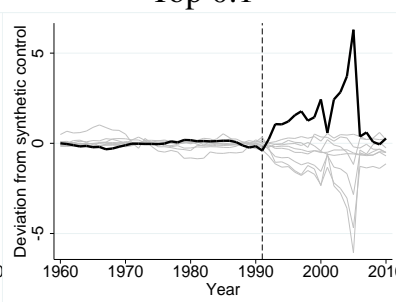

Top 5-1
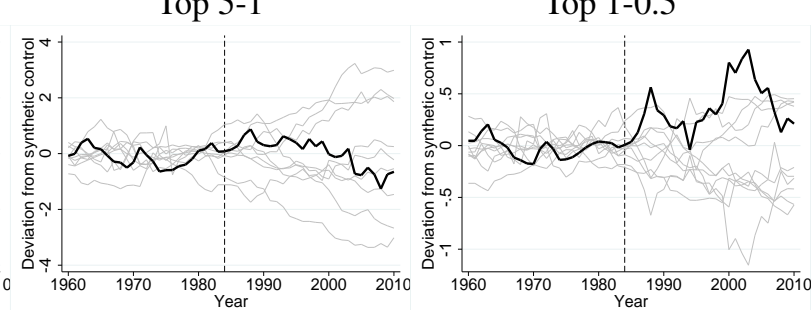

Top 5-1

Top 10-5
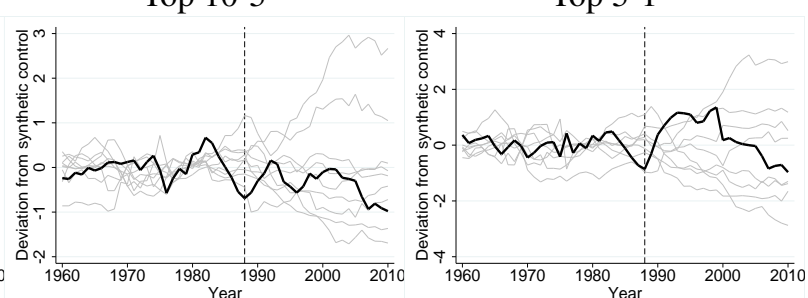

c) Norway

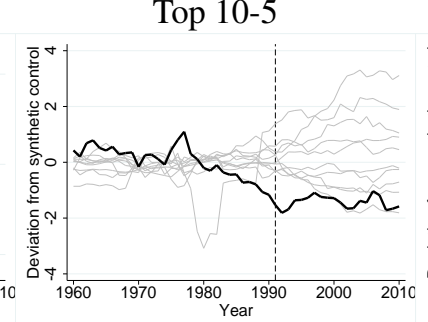

Top 1-0.5
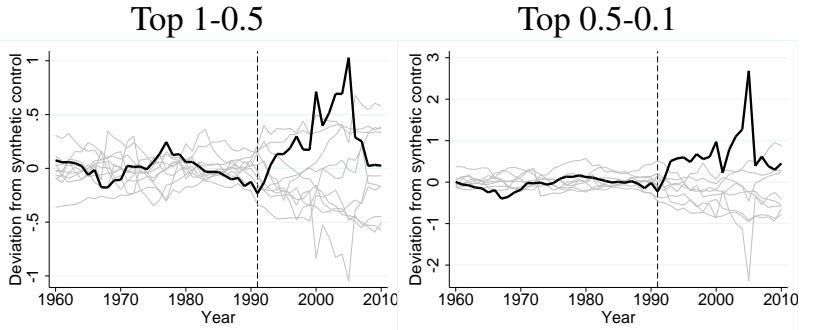

Note: The black solid line represents the deviation of the treated country from its synthetic control group. Each of the grey line represents a gap between the true outcome and the synthetic control group for every country in the donor pool (for which no deviation is expected). Countries with bad pre-treatment fit are ruled out as suggested by Abadie et al. (2010). 
Table C1: Statistical significance according to "in space" placebo test, full version

\begin{tabular}{|c|c|c|c|c|c|c|c|c|c|c|c|c|c|c|c|c|c|c|}
\hline & & & a) Aust & & & & & & b) New 2 & ealand & & & & & c) Nor & & & \\
\hline Year & 10 & 1 & 0.1 & $5-1$ & $1-0.5$ & $0.5-0.1$ & 10 & 1 & 0.5 & $10-5$ & $5-1$ & $1-0.5$ & 10 & 1 & 0.1 & $10-5$ & $1-0.5$ & $0.5-0.1$ \\
\hline 1985 & 0.27 & 0.18 & 0.11 & $\overline{0.4}$ & 0.27 & 0.14 & & & & & & & & & & & & \\
\hline 1986 & 0.09 & 0.18 & 0.11 & 0.3 & 0.09 & $<0.01$ & & & & & & & & & & & & \\
\hline 1987 & $<0.01$ & $<0.01$ & $<0.01$ & 0.1 & 0.09 & $<0.01$ & & & & & & & & & & & & \\
\hline 1988 & $<0.01$ & $<0.01$ & $<0.01$ & 0.2 & $<0.01$ & $<0.01$ & & & & & & & & & & & & \\
\hline 1989 & $<0.01$ & $<0.01$ & $<0.01$ & 0.3 & 0.09 & $<0.01$ & 0.18 & 0.27 & 0.1 & 0.8 & 0.67 & 0.2 & & & & & & \\
\hline 1990 & $<0.01$ & $<0.01$ & $<0.01$ & 0.3 & 0.09 & $<0.01$ & $<0.01$ & $<0.01$ & $<0.01$ & 0.9 & 0.22 & $<0.01$ & & & & & & \\
\hline 1991 & $<0.01$ & $<0.01$ & $<0.01$ & 0.3 & 0.09 & $<0.01$ & $<0.01$ & $<0.01$ & $<0.01$ & 0.5 & $<0.01$ & $<0.01$ & & & & & & \\
\hline 1992 & 0.09 & $<0.01$ & $<0.01$ & 0.3 & 0.18 & $<0.01$ & $<0.01$ & $<0.01$ & $<0.01$ & 0.1 & $<0.01$ & 0.1 & 0.73 & 0.33 & $<0.01$ & 0.91 & 0.45 & 0.11 \\
\hline 1993 & $<0.01$ & $<0.01$ & $<0.01$ & 0.1 & $<0.01$ & $<0.01$ & $<0.01$ & $<0.01$ & $<0.01$ & 0.4 & $<0.01$ & $<0.01$ & 0.09 & $<0.01$ & $<0.01$ & 0.91 & 0.27 & $<0.01$ \\
\hline 1994 & 0.09 & $<0.01$ & $<0.01$ & 0.3 & 0.18 & $<0.01$ & $<0.01$ & $<0.01$ & $<0.01$ & 0.5 & $<0.01$ & $<0.01$ & 0.09 & $<0.01$ & $<0.01$ & 0.91 & 0.18 & $<0.01$ \\
\hline 1995 & 0.18 & $<0.01$ & $<0.01$ & 0.3 & 0.09 & $<0.01$ & $<0.01$ & 0.09 & $<0.01$ & 0.6 & $<0.01$ & $<0.01$ & 0.09 & $<0.01$ & $<0.01$ & 0.91 & 0.18 & $<0.01$ \\
\hline 1996 & 0.18 & 0.09 & $<0.01$ & 0.3 & 0.18 & $<0.01$ & 0.09 & 0.09 & $<0.01$ & 0.7 & 0.22 & 0.1 & 0.09 & $<0.01$ & $<0.01$ & 0.91 & 0.18 & $<0.01$ \\
\hline 1997 & 0.09 & 0.09 & $<0.01$ & 0.3 & $<0.01$ & $<0.01$ & $<0.01$ & 0.09 & $<0.01$ & 0.5 & 0.22 & 0.1 & $<0.01$ & $<0.01$ & $<0.01$ & 0.91 & 0.18 & $<0.01$ \\
\hline 1998 & 0.09 & 0.18 & $<0.01$ & 0.3 & $<0.01$ & $<0.01$ & $<0.01$ & 0.09 & $<0.01$ & 0.4 & 0.22 & 0.1 & $<0.01$ & 0.17 & $<0.01$ & 0.91 & 0.18 & $<0.01$ \\
\hline 1999 & $<0.01$ & 0.09 & $<0.01$ & 0.3 & $<0.01$ & $<0.01$ & $<0.01$ & $<0.01$ & $<0.01$ & 0.6 & 0.11 & $<0.01$ & $<0.01$ & 0.17 & $<0.01$ & 0.91 & 0.18 & $<0.01$ \\
\hline 2000 & $<0.01$ & 0.09 & $<0.01$ & 0.3 & $<0.01$ & $<0.01$ & 0.18 & 0.18 & 0.3 & 0.4 & 0.27 & 0.2 & $<0.01$ & 0.08 & $<0.01$ & 0.82 & $<0.01$ & $<0.01$ \\
\hline 2001 & 0.09 & 0.09 & $<0.01$ & 0.3 & $<0.01$ & $<0.01$ & 0.09 & 0.27 & 0.3 & 0.3 & 0.27 & 0.2 & 0.09 & 0.17 & $<0.01$ & 0.82 & 0.09 & 0.11 \\
\hline 2002 & 0.09 & 0.09 & $<0.01$ & 0.3 & $<0.01$ & $<0.01$ & 0.09 & 0.27 & 0.2 & 0.3 & 0.27 & 0.3 & 0.09 & 0.17 & $<0.01$ & 0.82 & $<0.01$ & $<0.01$ \\
\hline 2003 & 0.09 & $<0.01$ & $<0.01$ & 0.3 & $<0.01$ & $<0.01$ & 0.09 & 0.27 & 0.1 & 0.4 & 0.36 & 0.3 & 0.09 & $<0.01$ & $<0.01$ & 0.82 & $<0.01$ & $<0.01$ \\
\hline 2004 & 0.09 & 0.18 & $<0.01$ & 0.4 & $<0.01$ & $<0.01$ & 0.09 & 0.18 & $<0.01$ & 0.4 & 0.36 & 0.3 & 0.09 & $<0.01$ & $<0.01$ & 0.82 & $<0.01$ & $<0.01$ \\
\hline 2005 & 0.18 & 0.09 & $<0.01$ & 0.5 & $<0.01$ & $<0.01$ & 0.18 & 0.36 & 0.1 & 0.5 & 0.36 & 0.3 & $<0.01$ & $<0.01$ & $<0.01$ & 0.82 & $<0.01$ & $<0.01$ \\
\hline 2006 & 0.09 & 0.09 & $<0.01$ & 0.5 & $<0.01$ & $<0.01$ & 0.27 & 0.45 & 0.2 & 0.5 & 0.36 & 0.5 & 0.09 & 0.27 & 0.11 & 0.82 & 0.27 & 0.11 \\
\hline 2007 & 0.27 & 0.09 & $<0.01$ & 0.5 & 0.27 & $<0.01$ & 0.27 & 0.54 & 0.3 & 0.6 & 0.36 & 0.6 & 0.09 & 0.27 & $<0.01$ & 0.82 & 0.27 & $<0.01$ \\
\hline 2008 & 0.36 & 0.09 & $<0.01$ & 0.6 & 0.36 & $<0.01$ & 0.27 & 0.36 & 0.2 & 0.7 & 0.36 & 0.7 & 0.18 & 0.27 & 0.22 & 0.82 & 0.36 & 0.11 \\
\hline 2009 & 0.27 & 0.09 & $<0.01$ & 0.6 & 0.36 & $<0.01$ & 0.27 & 0.36 & 0.2 & 0.7 & 0.36 & 0.6 & 0.18 & 0.42 & 0.33 & 0.82 & 0.36 & 0.11 \\
\hline 2010 & 0.27 & 0.09 & $<0.01$ & 0.6 & 0.36 & $<0.01$ & 0.36 & 0.54 & 0.3 & 0.7 & 0.36 & 0.7 & 0.09 & 0.33 & $<0.01$ & 0.82 & 0.36 & 0.11 \\
\hline
\end{tabular}

Note: this table shows, for each post-treatment year, the probability of getting a more extreme positive deviation from the synthetic control group than the deviation for the true treatment country. It relates to the graphs in Figure $\mathrm{C} 1$, as the number represents the share of grey lines that are higher than the black line for each post-treatment year. The population consists of the donor pool population for each top income share (all country with 0 or a positive weight in tables B1, B1B2, and B3). Countries with bad pre-treatment fit are ruled out as suggested by Abadie et al. (2010). 


\section{C2. Control variable test}

The potential determinants of top income share are various. The control variables selected in the baseline model do not cover, of course, the full set of potential determinants. Since the choice of controls included in vector of controls affects the optimization of the synthetic control, different combinations of controls are likely to generate different counterfactuals and, thus, different outcomes. A test to check whether the results depend on various combinations of variables is implemented. Figure 6 displays this robustness test, based on 35 different combinations of controls, arranged with three different set of years used to control for the top income trends. Tables C2 and C3 show all the different combinations of years and controls. Altogether, there are 105 different combinations and, thus, the same number of potentially different synthetic control for each country. To limit the number of figures, the outcome of the test is shown only for the top percentile.

The baseline result appears to be reproduced quite well by the alternative specifications. However, some alternative specifications, especially for New Zealand, produce a synthetic control with a lower outcome, inflating the effect of the treatment. On the other hand, Norway is fitted very well. This may be due to the fact that the donor pool is composed of few Englishspeaking countries from which the synthetic control can be picked (only Canada and Ireland), whereas Norway has more potentially similar countries (Denmark, Finland, Netherlands, and Sweden). Overall, the test does not complicate the robustness of the results. A broaden donor pool may improve the quality of the results, but the lack of data does not allow to do it. 
Table C2: Control variables combinations used in the selection of the Synthetic Control Group

\begin{tabular}{|c|c|c|c|c|c|c|c|c|c|c|c|c|c|c|c|c|c|c|c|c|c|c|c|c|c|c|c|c|c|c|c|c|c|c|c|}
\hline Variable & Base & & & & & & & & & & & & & nol & lat1 & as & sed & $\mathrm{n}$ th & $\mathrm{eco}$ & ntro & rob & ustn & ess & & & & & & & & & & & & \\
\hline GDP Per-Capita & $\mathrm{X}$ & & & & & $\mathrm{x}$ & $\mathrm{x}$ & $\mathrm{x}$ & $\mathrm{x}$ & $\mathrm{X}$ & $\mathrm{x}$ & $\mathrm{x}$ & $\mathrm{X}$ & $\mathrm{X}$ & $\mathrm{x}$ & $\mathrm{X}$ & $\mathrm{X}$ & $\mathrm{x}$ & $\mathrm{x}$ & $\mathrm{x}$ & $\mathrm{x}$ & $\mathrm{X}$ & $\mathrm{x}$ & $\mathrm{x}$ & $\mathrm{x}$ & $\mathrm{x}$ & $\mathrm{x}$ & $\mathrm{x}$ & $\mathrm{x}$ & & & $\mathrm{x}$ & & & \\
\hline GDP Growth Rate & & $\mathrm{X}$ & & & & & & & & & & & & & & & & & & & & & & & & & & & & & & & & $\mathrm{x}$ & \\
\hline MRP & & & & & & & & & & & & & $\mathrm{x}$ & & & & & & & & & & & & & & & & & & & & $\mathrm{x}$ & $\mathrm{x}$ & $\mathrm{X}$ \\
\hline ARP & $\mathrm{x}$ & $\mathrm{x}$ & $\mathrm{x}$ & $\mathrm{x}$ & $\mathrm{x}$ & $\mathrm{x}$ & $\mathrm{x}$ & $\mathrm{x}$ & $\mathrm{x}$ & $\mathrm{x}$ & $\mathrm{x}$ & $\mathrm{x}$ & & $\mathrm{x}$ & $\mathrm{x}$ & $\mathrm{x}$ & $\mathrm{x}$ & $\mathrm{x}$ & $\mathrm{x}$ & $\mathrm{x}$ & $\mathrm{x}$ & $\mathrm{x}$ & $\mathrm{x}$ & $\mathrm{x}$ & $\mathrm{x}$ & $\mathrm{x}$ & $\mathrm{x}$ & $\mathrm{x}$ & & $\mathrm{x}$ & $\mathrm{x}$ & $\mathrm{X}$ & & & $\mathrm{x}$ \\
\hline Party Orientation & & & & & & & & & & & $\mathrm{x}$ & & & & & & & & & & & & & & & & & & & & & & & $\mathrm{x}$ & $\mathrm{x}$ \\
\hline International Trade & & & & & & $\mathrm{x}$ & & & & & & & & & & & & & & & & & & & & & & & & & & & $\mathrm{x}$ & $\mathrm{x}$ & \\
\hline Globalization & $\mathrm{x}$ & $\mathrm{x}$ & $\mathrm{x}$ & $\mathrm{x}$ & $\mathrm{x}$ & & $\mathrm{x}$ & $\mathrm{x}$ & $\mathrm{x}$ & $\mathrm{x}$ & $\mathrm{x}$ & $\mathrm{x}$ & $\mathrm{x}$ & $\mathrm{x}$ & $\mathrm{x}$ & $\mathrm{x}$ & $\mathrm{x}$ & $\mathrm{x}$ & $\mathrm{x}$ & & $\mathrm{x}$ & $\mathrm{x}$ & $\mathrm{x}$ & $\mathrm{x}$ & $\mathrm{x}$ & $\mathrm{x}$ & $\mathrm{x}$ & & $\mathrm{x}$ & & $x$ & $x$ & & & \\
\hline Debt Growth Rate & $\mathrm{x}$ & $\mathrm{x}$ & $\mathrm{x}$ & $\mathrm{x}$ & $\mathrm{x}$ & $\mathrm{x}$ & $\mathrm{x}$ & $\mathrm{x}$ & $\mathrm{x}$ & $\mathrm{x}$ & $\mathrm{x}$ & $\mathrm{x}$ & $\mathrm{x}$ & $\mathrm{x}$ & $\mathrm{x}$ & & & & & & $\mathrm{x}$ & $\mathrm{x}$ & $\mathrm{x}$ & $\mathrm{x}$ & $\mathrm{x}$ & $\mathrm{x}$ & $\mathrm{x}$ & & $\mathrm{x}$ & $\mathrm{x}$ & $\mathrm{x}$ & $\mathrm{x}$ & & & \\
\hline Government Spending & & & & & & & & & & & & & & & & $\mathrm{x}$ & & & & & & & & & & & & & & & & & $\mathrm{x}$ & & \\
\hline Gross Savings & & & & & $\mathrm{x}$ & & & & & & & & & & & & & & & & & & & & & & & & & & & & & & $\mathrm{x}$ \\
\hline Gross Fixed Capital & & & & $\mathrm{x}$ & & & & & & & & & & & & & & & & & & & & & & & & & & & & & & & $\mathrm{x}$ \\
\hline Bank Deposits & & & & & & & $\mathrm{x}$ & & & & & & & & & & & & & & & & & & & & & & & & & & & $\mathrm{x}$ & $\mathrm{x}$ \\
\hline UK Legal Origin & & & & & & & & & & & & $\mathrm{x}$ & & & & & & & & & & & & & & & & & & & & & $\mathrm{x}$ & & $\mathrm{x}$ \\
\hline Population Growth & & & & & & & & & & & & & & & & & & & & & & & & & & & & & & & & & & $\mathrm{x}$ & \\
\hline Working Age Pop & & & & & & & & & $\mathrm{x}$ & & & & & & & & & & & & & & & & & & & & & & & & $\mathrm{x}$ & & $\mathrm{X}$ \\
\hline Annual Hours Worked & $\mathrm{x}$ & $\mathrm{x}$ & $\mathrm{x}$ & $\mathrm{x}$ & $\mathrm{x}$ & $\mathrm{x}$ & $\mathrm{x}$ & $\mathrm{x}$ & & & $\mathrm{x}$ & $\mathrm{x}$ & $\mathrm{x}$ & $\mathrm{x}$ & $\mathrm{x}$ & $\mathrm{x}$ & $\mathrm{x}$ & $\mathrm{x}$ & $\mathrm{x}$ & $\mathrm{x}$ & $\mathrm{x}$ & $\mathrm{x}$ & $\mathrm{x}$ & & $\mathrm{x}$ & $\mathrm{x}$ & $\mathrm{x}$ & $\mathrm{x}$ & $\mathrm{x}$ & $\mathrm{x}$ & $\mathrm{x}$ & $\mathrm{x}$ & & & \\
\hline Trade Union Density & $\mathrm{x}$ & $\mathrm{x}$ & $\mathrm{x}$ & $\mathrm{x}$ & $\mathrm{x}$ & $\mathrm{x}$ & $\mathrm{x}$ & $\mathrm{x}$ & $\mathrm{x}$ & $\mathrm{x}$ & & & $\mathrm{x}$ & $\mathrm{x}$ & $\mathrm{x}$ & $\mathrm{x}$ & $\mathrm{x}$ & $\mathrm{x}$ & $\mathrm{x}$ & $\mathrm{x}$ & $\mathrm{x}$ & $\mathrm{x}$ & $\mathrm{x}$ & $\mathrm{x}$ & $\mathrm{x}$ & $\mathrm{x}$ & $\mathrm{x}$ & $\mathrm{x}$ & $\mathrm{x}$ & $\mathrm{x}$ & $\mathrm{x}$ & $\mathrm{x}$ & & & \\
\hline Stock Market & & & & & & & & $\mathrm{x}$ & & & & & & & & & & & & & & & & & & & & & & & & & $\mathrm{x}$ & & \\
\hline Financial Development & $\mathrm{x}$ & $\mathrm{x}$ & $\mathrm{x}$ & $\mathrm{x}$ & $\mathrm{x}$ & $\mathrm{x}$ & & & $\mathrm{x}$ & $\mathrm{x}$ & $\mathrm{x}$ & $\mathrm{x}$ & $\mathrm{x}$ & $\mathrm{x}$ & $\mathrm{x}$ & $\mathrm{x}$ & $\mathrm{x}$ & $\mathrm{x}$ & $\mathrm{x}$ & $\mathrm{x}$ & $\mathrm{x}$ & $\mathrm{x}$ & & $\mathrm{x}$ & $\mathrm{x}$ & $\mathrm{x}$ & $\mathrm{x}$ & $\mathrm{x}$ & $\mathrm{x}$ & $\mathrm{x}$ & & & & & \\
\hline Patents Growth Rate & & & & & & & & & & $\mathrm{x}$ & & & & & & & & & & & & & & & & & & & & & & & $\mathrm{x}$ & & \\
\hline High Education & & & & & & & & & & & $\mathrm{x}$ & & & & & & & & & & & & & & & & & & & & & & & $\mathrm{x}$ & \\
\hline Enrollment Ratio & & & & & & & & & & & $\mathrm{x}$ & & & & & & & & & & & & & & & & & & & & & & $\mathrm{x}$ & & $\mathrm{X}$ \\
\hline Human Capital & $\mathrm{x}$ & $\mathrm{x}$ & $\mathrm{x}$ & $\mathrm{x}$ & $\mathrm{x}$ & $\mathrm{x}$ & $\mathrm{x}$ & $\mathrm{x}$ & $\mathrm{x}$ & & & $\mathrm{x}$ & $\mathrm{X}$ & $\mathrm{x}$ & $\mathrm{x}$ & $\mathrm{x}$ & $\mathrm{X}$ & $\mathrm{X}$ & $\mathrm{x}$ & $\mathrm{x}$ & $\mathrm{X}$ & $\mathrm{x}$ & $\mathrm{X}$ & $\mathrm{x}$ & $\mathrm{x}$ & $\mathrm{x}$ & $\mathrm{X}$ & $\mathrm{x}$ & $\mathrm{x}$ & $\mathrm{x}$ & $\mathrm{x}$ & $\mathrm{X}$ & & & \\
\hline Tax Revenue & & & & & & & & & & & & & & & & & $\mathrm{x}$ & & $\mathrm{x}$ & & & & & & & & & & & & & & $\mathrm{x}$ & & $\mathrm{X}$ \\
\hline
\end{tabular}

Note: This table shows the different combinations of the vector of controls $Z$ used to estimate the synthetic control. There are 35 different combinations, arranged with three different set of years (displayed in Table 15), for a total of 105 combinations. Outcomes are shown in Figure 6. Control variables are described in Table 8. 
Table C3: Years in Synthetic Control Group choice function

\begin{tabular}{lcc|ccc|ccc}
\multicolumn{3}{c|}{ Australia } & \multicolumn{3}{c|}{ New Zealand } & \multicolumn{3}{c}{ Norway } \\
\hline Baseline & Version 2 & Version 3 & Baseline & Version 2 & Version 3 & Baseline & Version 2 & Version 3 \\
\hline \hline 1965 & 1962 & 1967 & 1969 & 1967 & 1965 & 1965 & 1964 & 1968 \\
1975 & 1972 & 1976 & 1981 & 1983 & 1982 & 1988 & 1987 & 1988 \\
1983 & 1983 & 1982 & 1987 & 1987 & 1986 & 1990 & 1990 & 1989 \\
\hline \hline
\end{tabular}

\section{C3. "In-time" placebo test}

"In-time" falsification exercises are made simulating a placebo treatment some years before (8, 10 and 13 years) and after (8,10 and 15 years) the real treatment. To limit the number of graphs, those tests are carried out only for the top percentile, since this share can be assumed as representative. The tests reinforce the robustness of results, since the effect appears only in the years after the reform. The only bad new - but however not very sizable - comes from the test carries out in Norway 13 years before the reform (in 1978). Here a negative effect is found. However, when the placebo is handed out in 1981 and 1984 (respectively 10 and 8 years before the real treatment), this troubling effect was absorbed by the synthetic control.

Figure C2: "In-time" placebo test

\section{a) Australia}
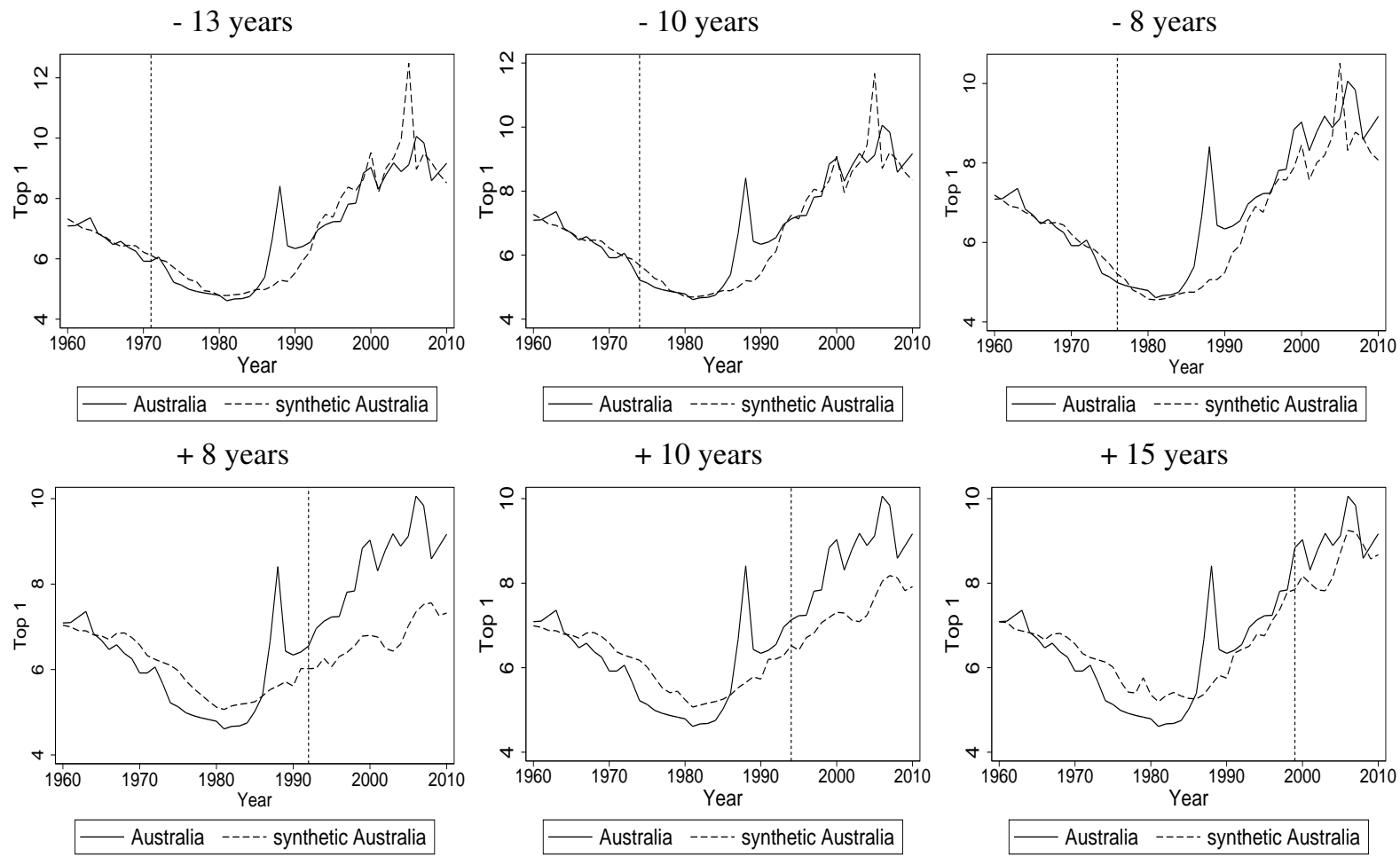


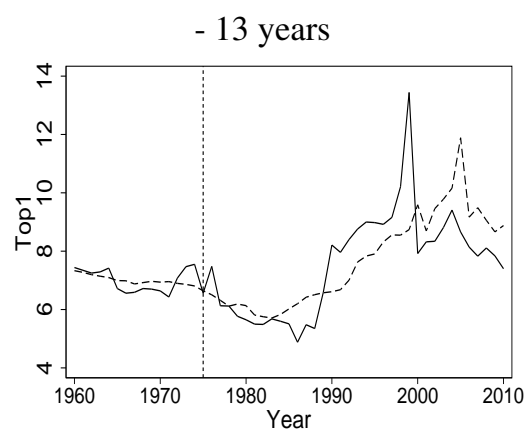

- New Zealand ----- synthetic New Zealand

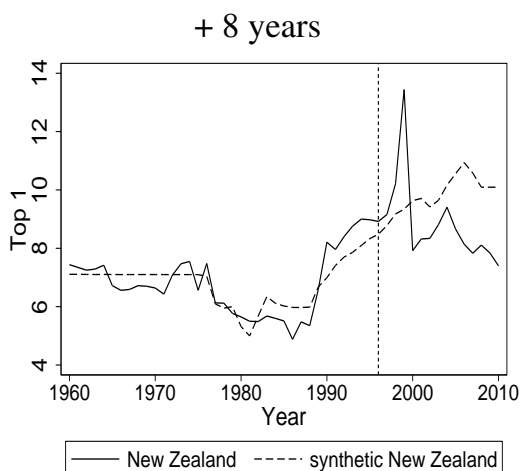

-New Zealand ----. synthetic New Zealand b) New Zealand

-10 years

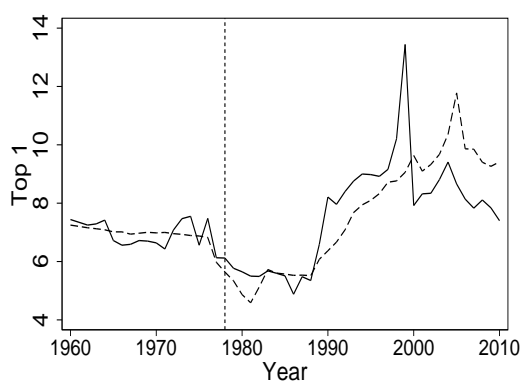

- New Zealand ----- synthetic New Zealand

+10 years

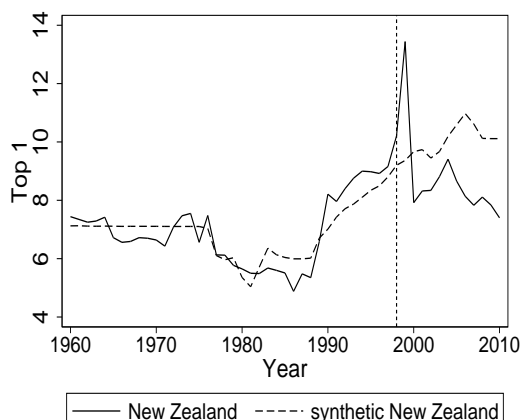

- New Zealand -----. synthetic New Zealand

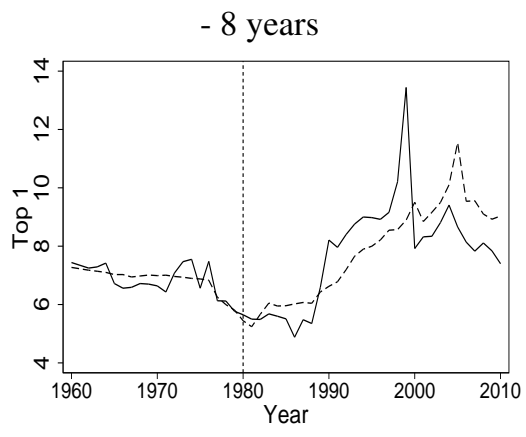

- New Zealand -----. synthetic New Zealand

+15 years

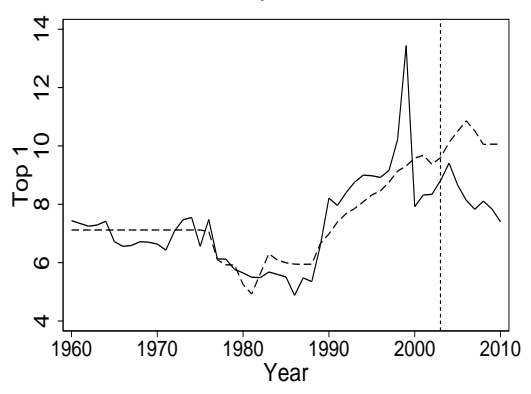

- New Zealand -----. synthetic New Zealand c) Norway

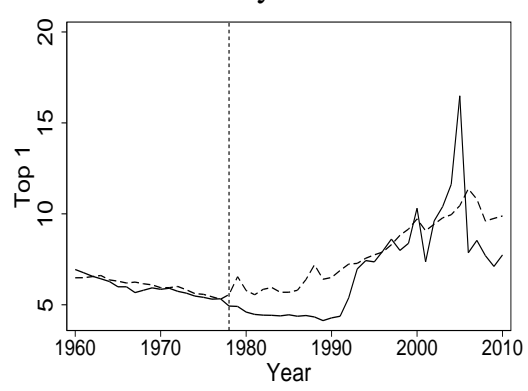

- Norway ----- synthetic Norway

+8 years

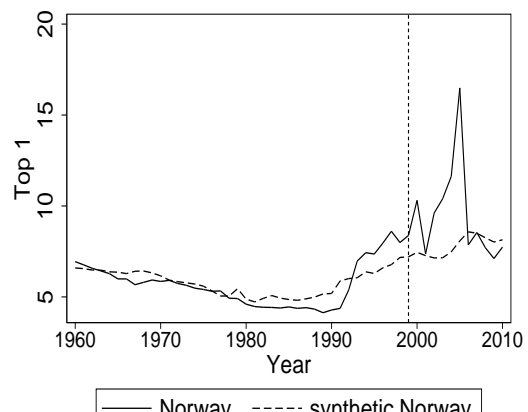

-10 years

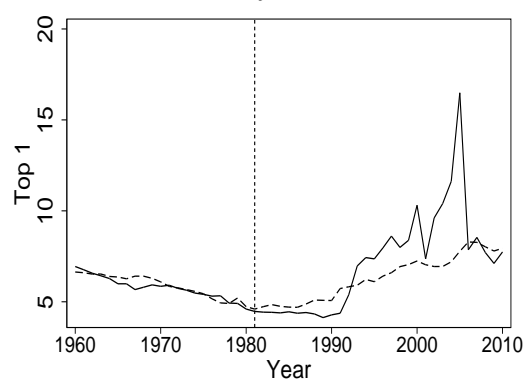

- Norway ----- synthetic Norway

+10 years

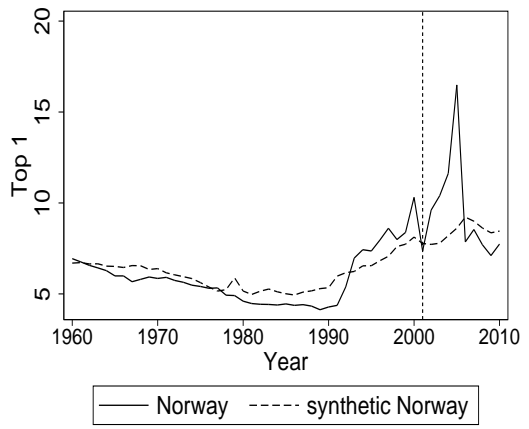

-8 years

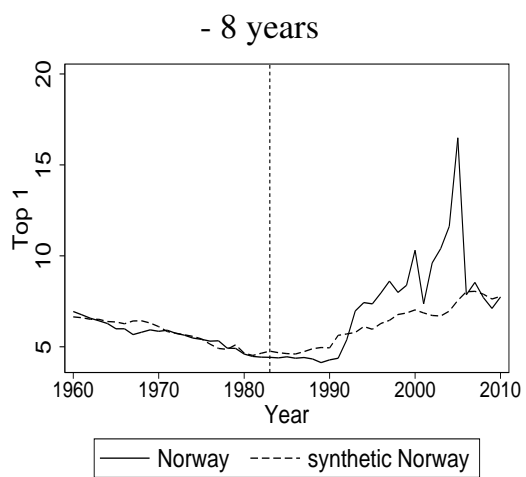

+15 years

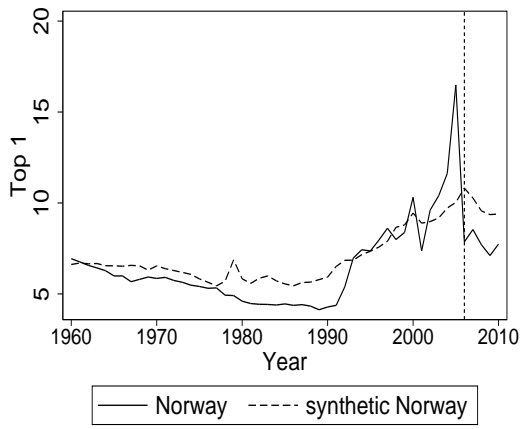

Note: This test imposes falsely timed tax reforms in the three studied countries 8,10 and 13 years before and 8,10 and 15 years after the actual reform. 


\section{C4. Post-treatment trends in control variables}

An implicit assumption of the SCM is that trends in both treated and synthetic control are parallel after the treatment. The optimization problem solved by the SCM generates the synthetic control that best resembles the pre-treatment characteristics of the country in which the reform was implemented. However, it is entirely possible that important economic changes happened in the years after the reform in both the synthetic control or the treated country. If this happens, the estimations would be severely biased. This is more than solely a potential issue, since changes in the economic environment can occur quite frequently. For this purpose, post-treatment trends in both the treated and the respective synthetic control are examined for each group within the top.

The graphical analysis reassures about this potential severe issue. The only notable deviation is that trade union density fell relatively sharp after the tax reform in New Zealand. This can be explained by the fact that a labor reform was implemented in the same period of the fiscal reform analyzed. Therefore, the role of trade union has been weakened. Other deviations are observed in the variables reflecting the fiscal status of the country (ARP, debt growth rate, MTR). Reductions in such variables are not problematical, since they are directly affected by the tax reform. 
Figure C3: Post-treatment trends in control variables

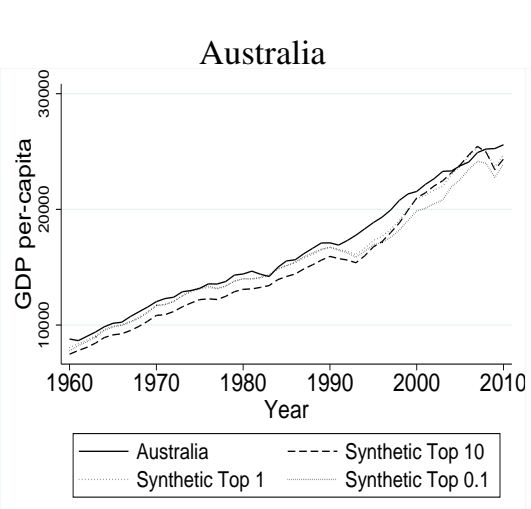

Australia

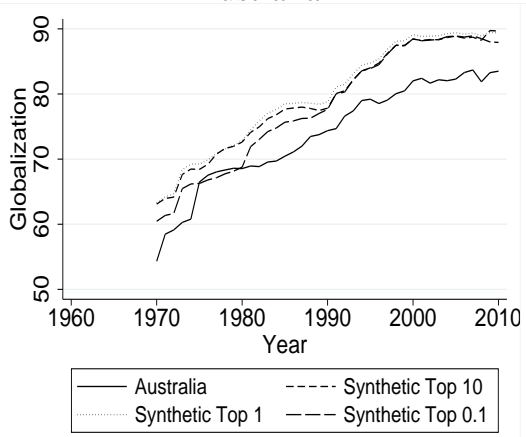

Australia

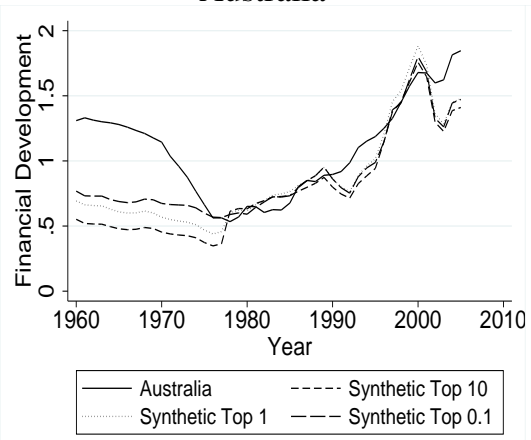

Australia

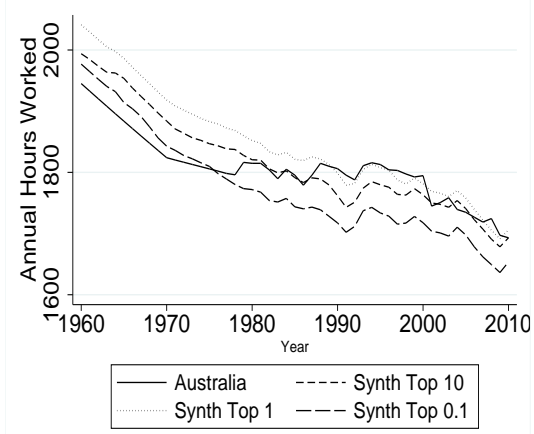

a) GDP per-capita
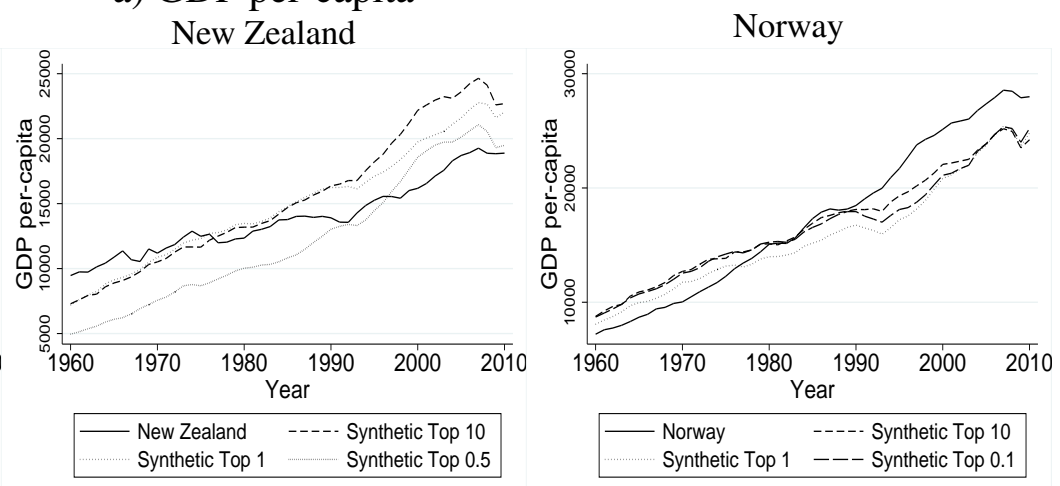

b) Globalization

New Zealand
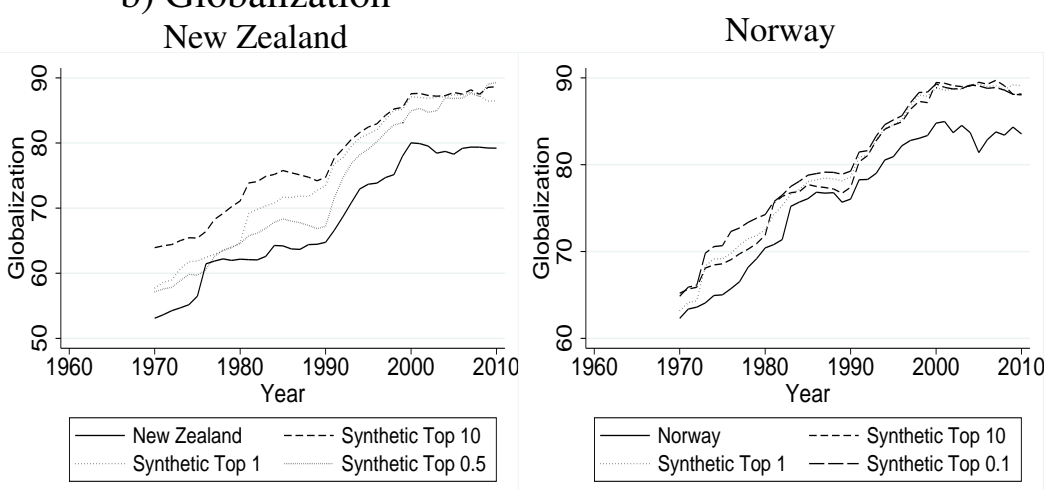

c) Financial Development

New Zealand

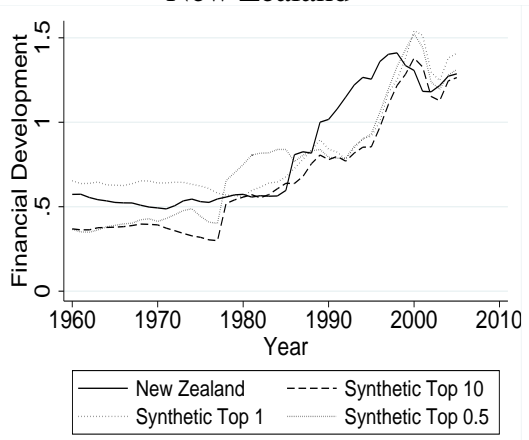

Norway

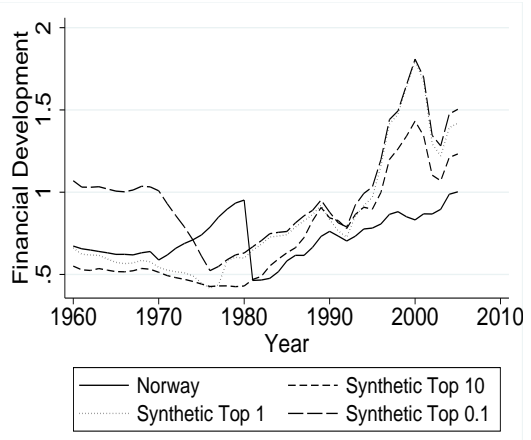

d) Annual Hours Worked

New Zealand

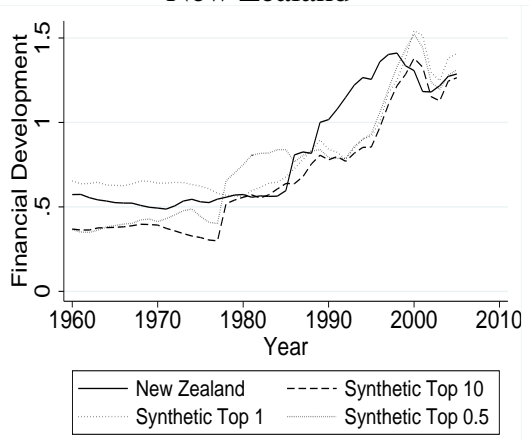

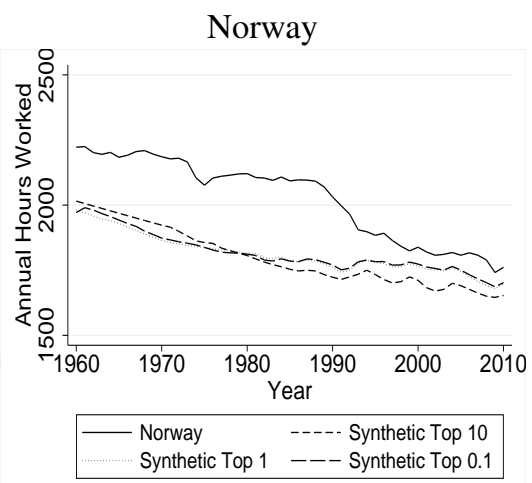

Continues on next page 

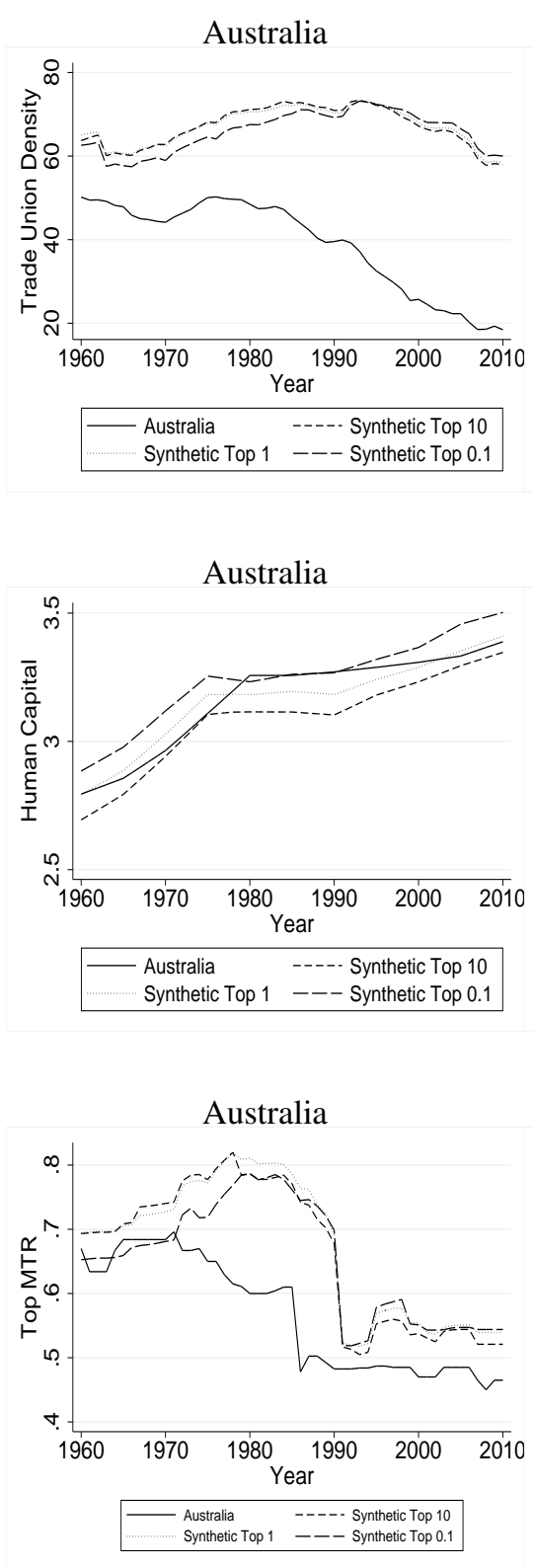

Australia

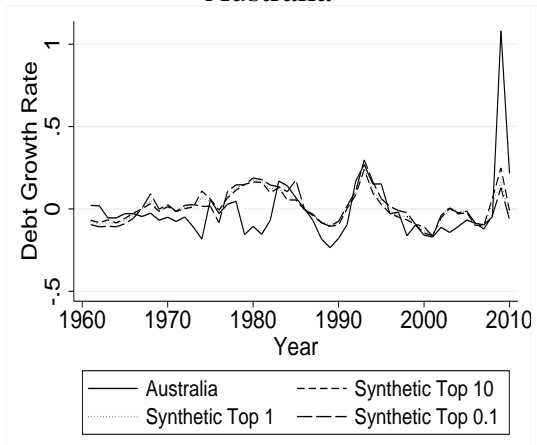

e) Trade Union Density
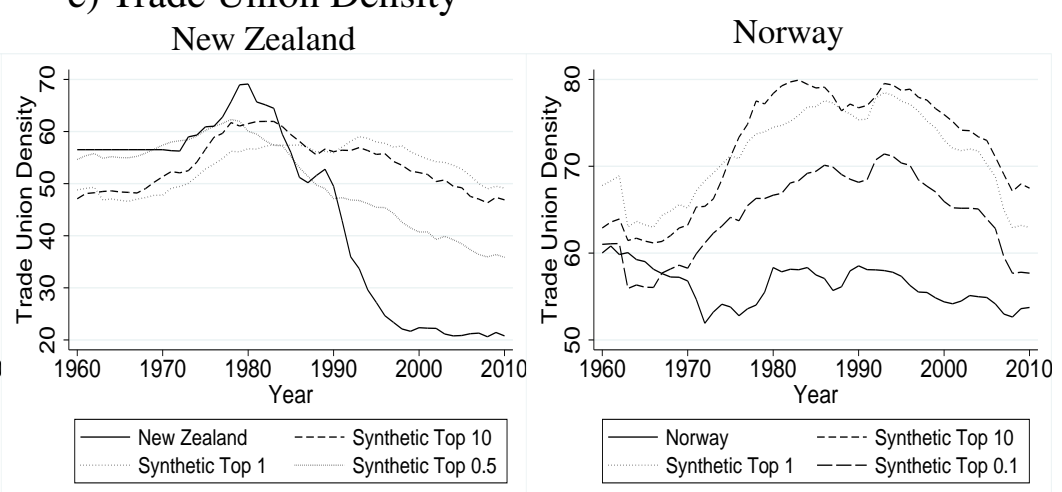

f) Human Capital
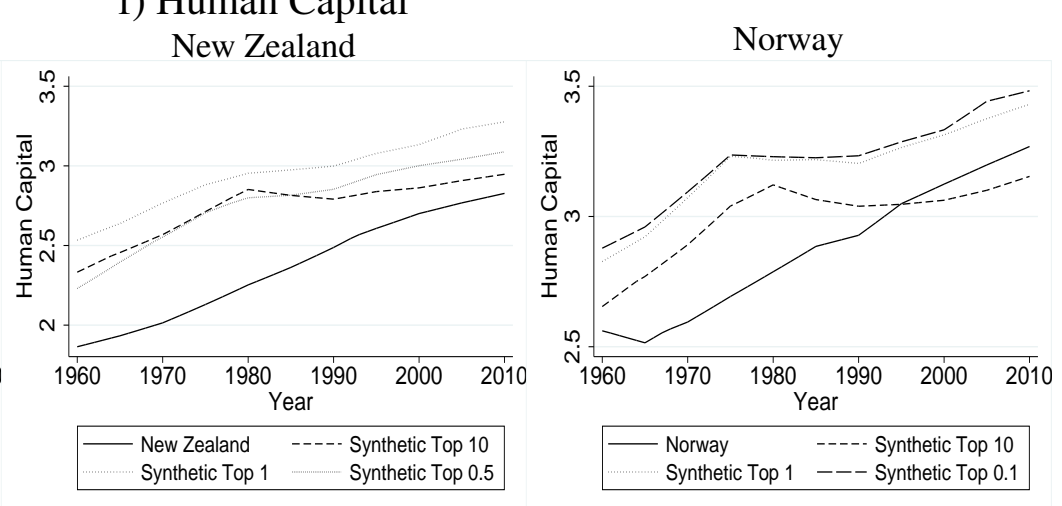

g) $M T R^{t o p}$

New Zealand
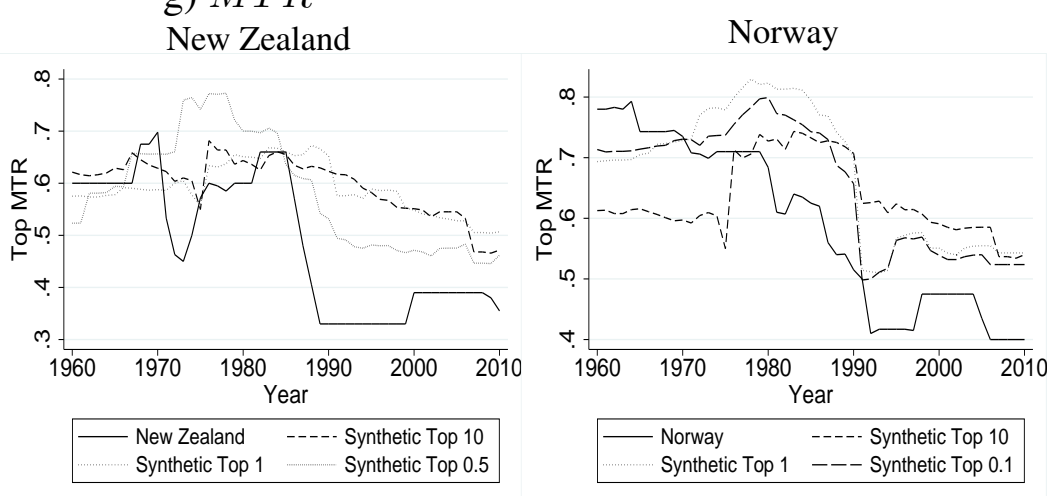

g) Debt Growth Rate

New Zealand

Norway
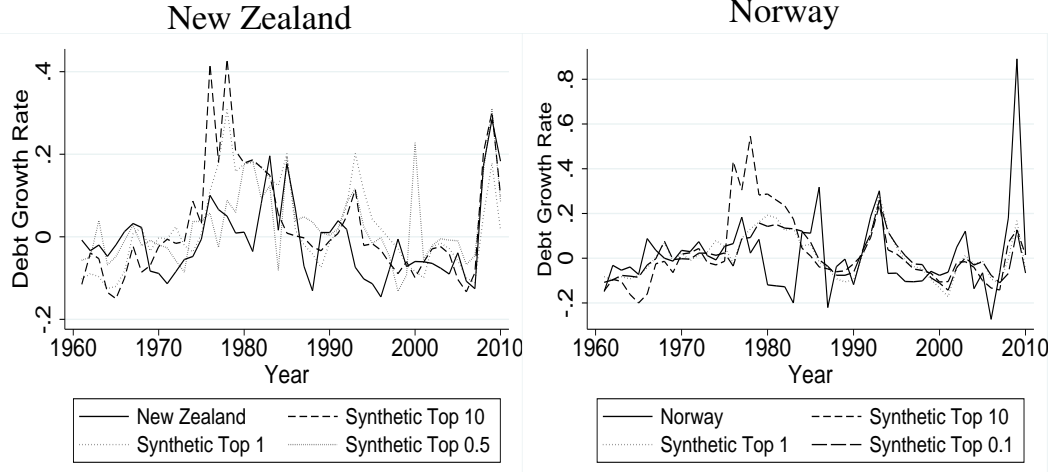

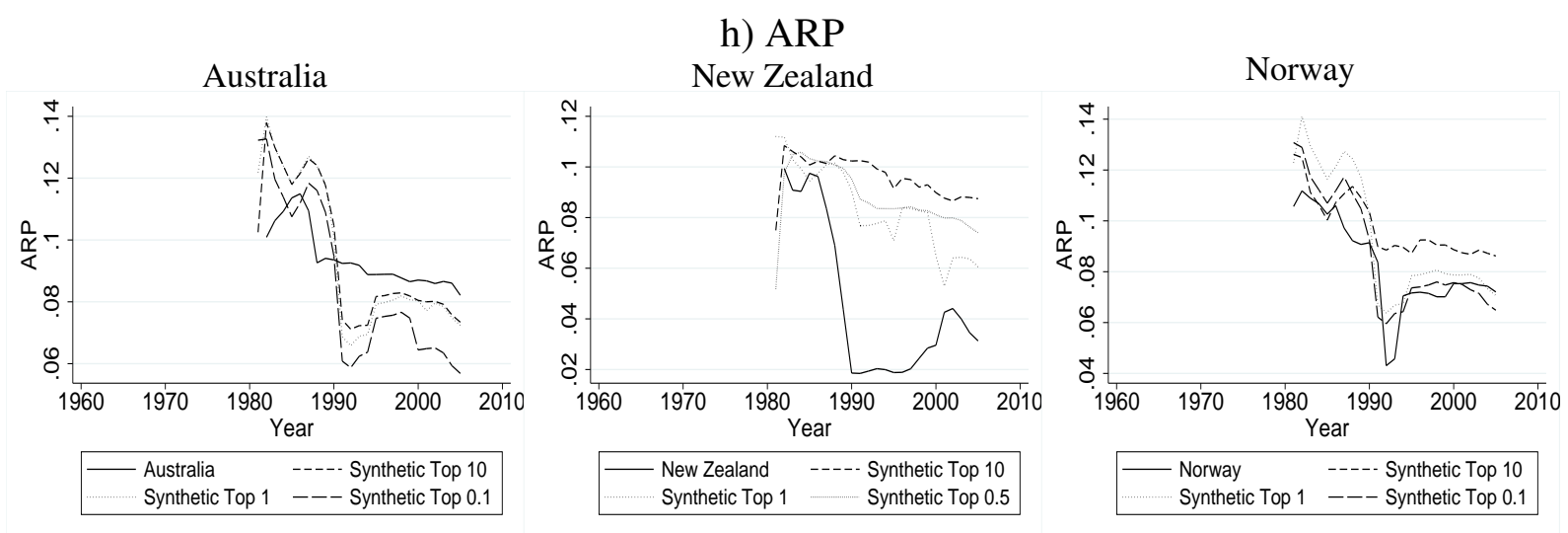

\section{C5. Effect of using a sub-donor pool which includes realized capital gains}

Capital gains turn out to be an important potential explanation of the effect of the reform on top income shares, especially for the groups at the very top. Theoretically capital gains, both realized and unrealized, are undoubtedly a source of income in the classic Haig-Simons definition. However, capital gains represent a highly complicate income component to include in an individual's income (Roine and Waldenström, 2015). Only when they are realized, they become observable and, then, appear on tax returns. It makes difficult to allocate them properly in time. Exclusion and inclusion of capital gains can change the top income series, especially in the very top groups, since capital gains are more important for the richest individuals.

Table A2 displays that capital gains are not included in each country data. Problems with observing and accurately dating capital gains have led many researchers to exclude the realized capital gains from their top income series. For some countries WID presents top income shares both including and excluding realized capital gains. Separate series, among the countries included in the donor pool, can be found in Canada, Germany, Japan, Spain, and Sweden. The treated countries present only series where capital gains are included in the tax base. A more accurate analysis should consider a sub-donor pool composed only of the countries for which series containing capital gains are available. This group is formed by Canada, Germany, Japan, Spain, and Sweden ${ }^{19}$.

Figure $\mathrm{C} 4$ compares the outcomes when the synthetic control is optimized with the original donor pool and the new sub-donor pool. The results show that top income shares are lower in the sub-donor pool where realized capital gains are included, especially for the groups at the very top. It suggests that realized capital gains are an important driver of the spike observed after the reform and that using the original donor pool may tend to overstate increases in top income shares. However, it should be noted that the sub-donor pool is composed of only 5 countries, leading to worse synthetic control. Indeed, the pre-treatment trends are better reproduced by the original donor pool with more countries. A larger sample which could allow to include capital

\footnotetext{
${ }^{19}$ Canada data is available from 1972 to 2010 (since 1982, series from LAD). For Germany and Spain the same linear interpolations described in Table 6 are made.
} 
gains may further help to understand the real development of top income shares.

Comprehensive tax reform legislation as the ones under examination should be considered cautionary when comparing pre- and post-period of reform. Burkhauser et al. (2015) discuss how the Australian reform may substantially alter Australian top income series. They provide an estimation of the top percentile from 1970 to 2010, which takes into account the change on the treatment of company profits and dividends induced by the tax reform. Figure C5 displays the effect of the reform on top percentile and the SCM result using Burkhauser et al. (2015)'s data. Using those corrected data, the surge in top income shares is still notable, even if weaker than the original estimation made using WID top income series. 
Figure C4: The effect of realized capital gains

a) Australia

Sub-donor pool

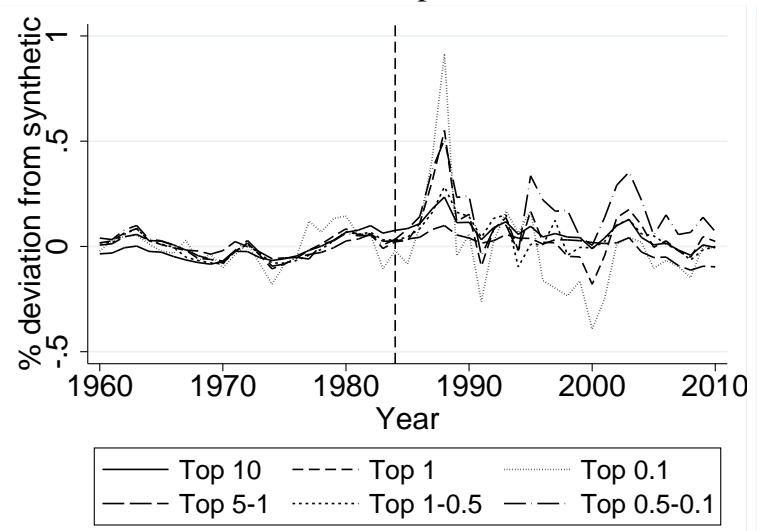

Original donor pool

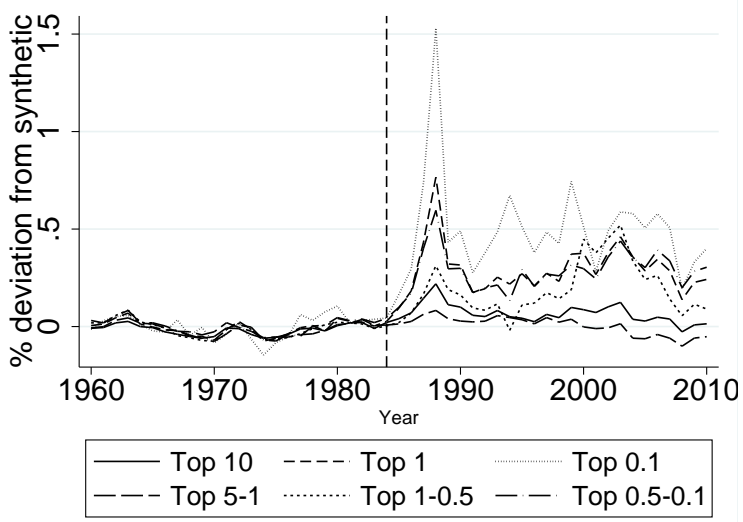

b) New Zealand

Sub-donor pool

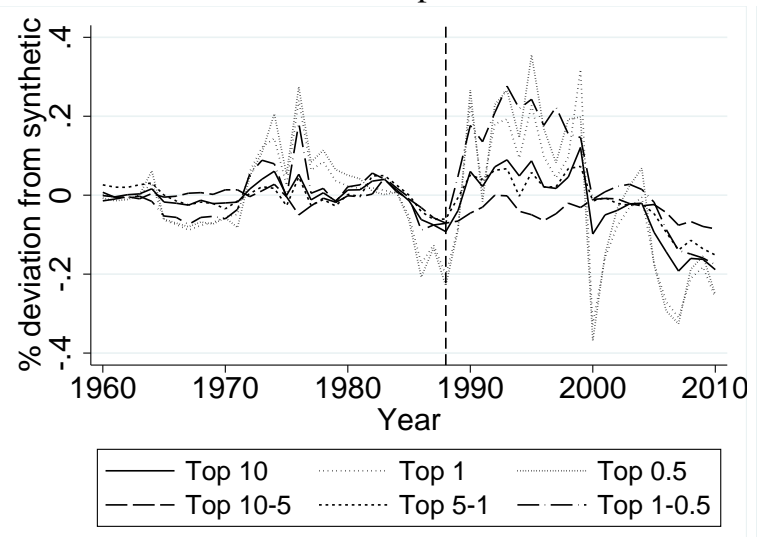

Original donor pool

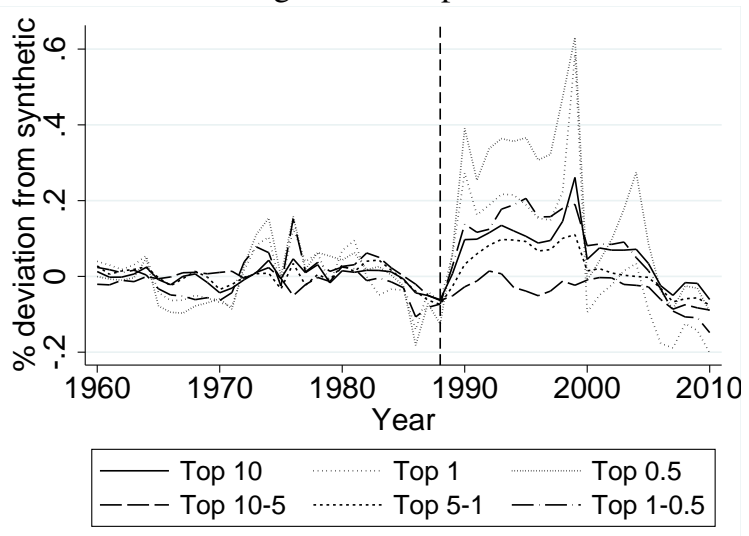

c) Norway

Sub-donor pool

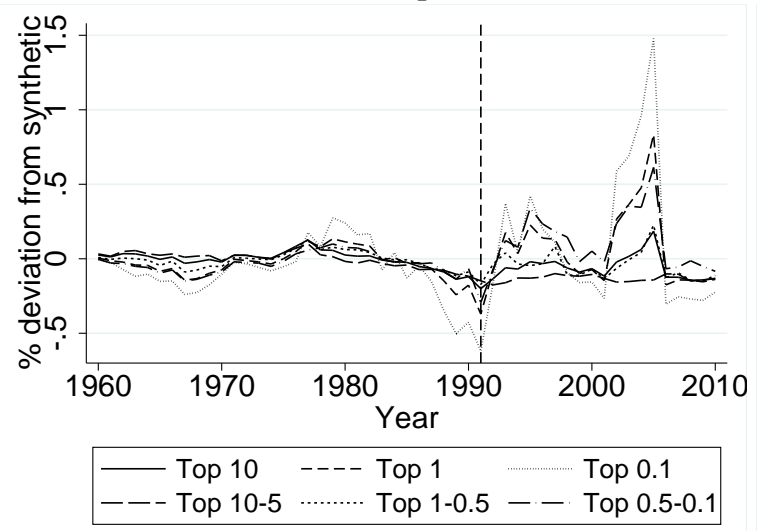

Original donor pool

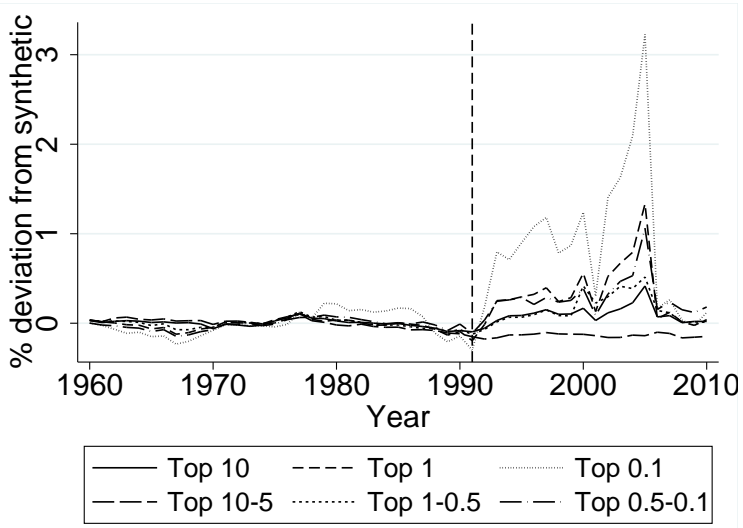

Note: Percentage deviations from the synthetic control group for each top income share. The figures on the right display outcome using the baseline original donor pool. Figures on the left use a restricted donor pool containing only the countries having separate top income series including capital gains (Canada, Germany, Japan, Spain, and Sweden). 
Figure C5: Burkhauser at al. (2015) for Australia: comparison and results

a) Australia, comparison between series

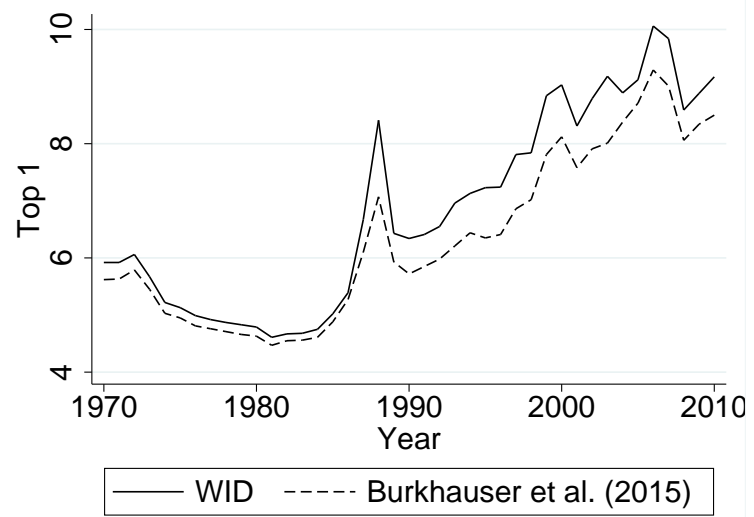

b) Australia, alternative estimation

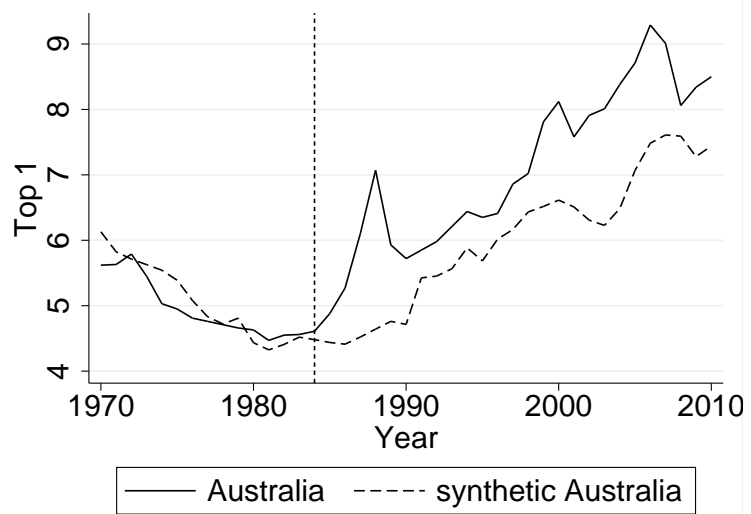

Note: Figure a) compares top income series from WID and Burkhauser et al. (2015). Burkhauser et al. (2015, Appendix Table A3) data excludes dividend imputation credits from top income share. Figure b) replicates the estimation whose outcome is displayed in Figure 4 using data on top percentile from Burkhauser et al. (2015, Appendix Table A3) instead of the original WID source. Burkhauser et al. (2015, Appendix Table A3) data excludes dividend imputation credits from top income share.

Figure $\mathrm{C} 4$ and $\mathrm{C} 5$ both suggest that the original estimations may inflate top income shares. However, the effect of the reform on top income shares is still evident accounting for realized capital gains and changes in the treatment of company tax in Australia.

\section{Appendix D: Additional regressions and other dimensions of tax reforms}

The baseline model, shown in Table 3, uses marginal measures of tax rate and tax progressivity. We re-run panel regressions replacing MTR and MRP with ATR and ARP and then we use both in the same regression to evaluate which effect predominates. 
Table D1: Marginal vs average effects, 1981-2010

\section{i) ATR vs MTR}

\begin{tabular}{l|cc|cc|cc} 
& \multicolumn{2}{|c|}{ Top 10-5 } & \multicolumn{2}{c|}{ Top 1-0.5 } & \multicolumn{2}{c}{ Top 0.1 } \\
\hline $1-A T R^{s}$ & $-0.093^{* * *}$ & -0.11 & $0.183^{* * *}$ & -0.032 & $0.911^{* * *}$ & $-0.688^{* *}$ \\
& $(0.032)$ & $(0.072)$ & $(0.049)$ & $(0.112)$ & $(0.22)$ & $(0.285)$ \\
\hline $1-M T R^{s}$ & & 0.013 & & $0.16^{*}$ & & $1.416^{* * *}$ \\
& & $(0.044)$ & & $(0.081)$ & & $(0.274)$ \\
\hline Obs. & 356 & 356 & 383 & 383 & 306 & 306 \\
\hline
\end{tabular}

\begin{tabular}{|c|c|c|c|c|c|c|}
\hline \multicolumn{7}{|c|}{ ii) ARP vs MRP } \\
\hline & \multicolumn{2}{|c|}{ Тор 10-1 } & \multicolumn{2}{|c|}{ Top 1-0.1 } & \multicolumn{2}{|c|}{ Tор 0.1} \\
\hline$A R P$ & $\begin{array}{c}0.03 \\
(0.02)\end{array}$ & $\begin{array}{c}0.092 * * * \\
(0.028)\end{array}$ & $\begin{array}{c}-0.12 * * * \\
(0.033)\end{array}$ & $\begin{array}{c}0.041 \\
(0.051)\end{array}$ & $\begin{array}{c}-0.21^{* * * *} \\
(0.085)\end{array}$ & $\begin{array}{c}0.069 \\
(0.098)\end{array}$ \\
\hline$M R P$ & & $\begin{array}{c}-0.078^{* * *} \\
(0.019)\end{array}$ & & $\begin{array}{c}-0.201^{* * *} \\
(0.048)\end{array}$ & & $\begin{array}{c}-0.373 * * * \\
(0.114)\end{array}$ \\
\hline Obs. & 377 & 377 & 377 & 377 & 304 & 304 \\
\hline
\end{tabular}

Note: Panel i) shows $e_{A T R}^{s}$ and $e_{M T R}^{s}$ coefficients from regressions of the form $y_{s, i, t}=e_{A T R}^{s} \log (1-$ $\left.A T R_{i, t}^{s}\right)+e_{M T R}^{s} \log \left(1-M T R_{i, t}^{s}\right)+\beta_{2}^{s} Z_{i, t}+\gamma_{t}^{s}+\mu_{i}^{s}+\mu_{i}^{s} t^{s}+u_{i, t}^{s}$. Since $A T R^{10-1}$ and $A T R^{1-0.1}$ are not available, we replace them with $A T R^{10-5}$ and $A T R^{1-0.5}$. Panel ii) shows $e_{A R P}^{s}$ and $e_{M R P}^{s}$ coefficients from regressions of the form $y_{s, i, t}=e_{A R P}^{s} \log \left(A R P_{i, t}\right)+e_{M R P}^{s} \log \left(M R P_{i, t}\right)+\beta_{2}^{s} Z_{i, t}+\gamma_{t}^{s}+\mu_{i}^{s}+\mu_{i}^{s} t^{s}+$ $u_{i, t}^{s}$. We use Newey-West standard errors with 8 lags in parenthesis. Data on tax rates are authors computations from OECD national tax schedules. Data on progressivity indicators are from Andrew Young School of Policy Studies (2010). Data on top income shares are from WID. ${ }^{* * *} \mathrm{p}<0.01,{ }^{* *} \mathrm{p}<0.05,{ }^{*} \mathrm{p}<0.1$.

As standard economic theory predicts, marginal effects dominates average effects. This is confirmed both using tax rate and progressivity measures. 


\section{Appendix References}

Andrew Young School of Policy Studies. (2010). "Andrew Young School World Tax Indicators (Volume 1) [Data file, data description, and data appendix]." Retrieved from http://aysps.gsu.edu/isp/wti.html

Barro, R. J., J.W. Lee (2013). "A new data set of educational attainment in the world, 1950-2010." Journal of development economics, 104, 184-198.

Dreher, A. (2006). "Does globalization affect growth? Evidence from a new Index of Globalization." Applied Economics 38, 10: 1091-1110.

Feenstra, R. C., R. Inklaar, M. P. Timmer (2015). The next generation of the Penn World Table. The American Economic Review, 105(10), 3150-3182.

Keefer, P. (2005). "Database of political institutions." Development Research Group, World Bank.

La Porta, R., F. Lopez-de-Silanes, A. Shleifer, R. W. Vishny (1997). "Legal determinants of external finance." Journal of finance 52(3): 1131-1150.

OECD (2016), Working age population (indicator). doi: 10.1787/d339918b-en (Accessed Feb. 2016)

Psacharopoulos, G. (1994). "Returns to investment in education: A global update." World development, 22(9), 1325-1343.

United Nations Educational, Scientific, and Cultural Organization (UNESCO) Institute for Statistics.

World Bank Group (Ed.). (2012). World Development Indicators 2012. World Bank Publications. 